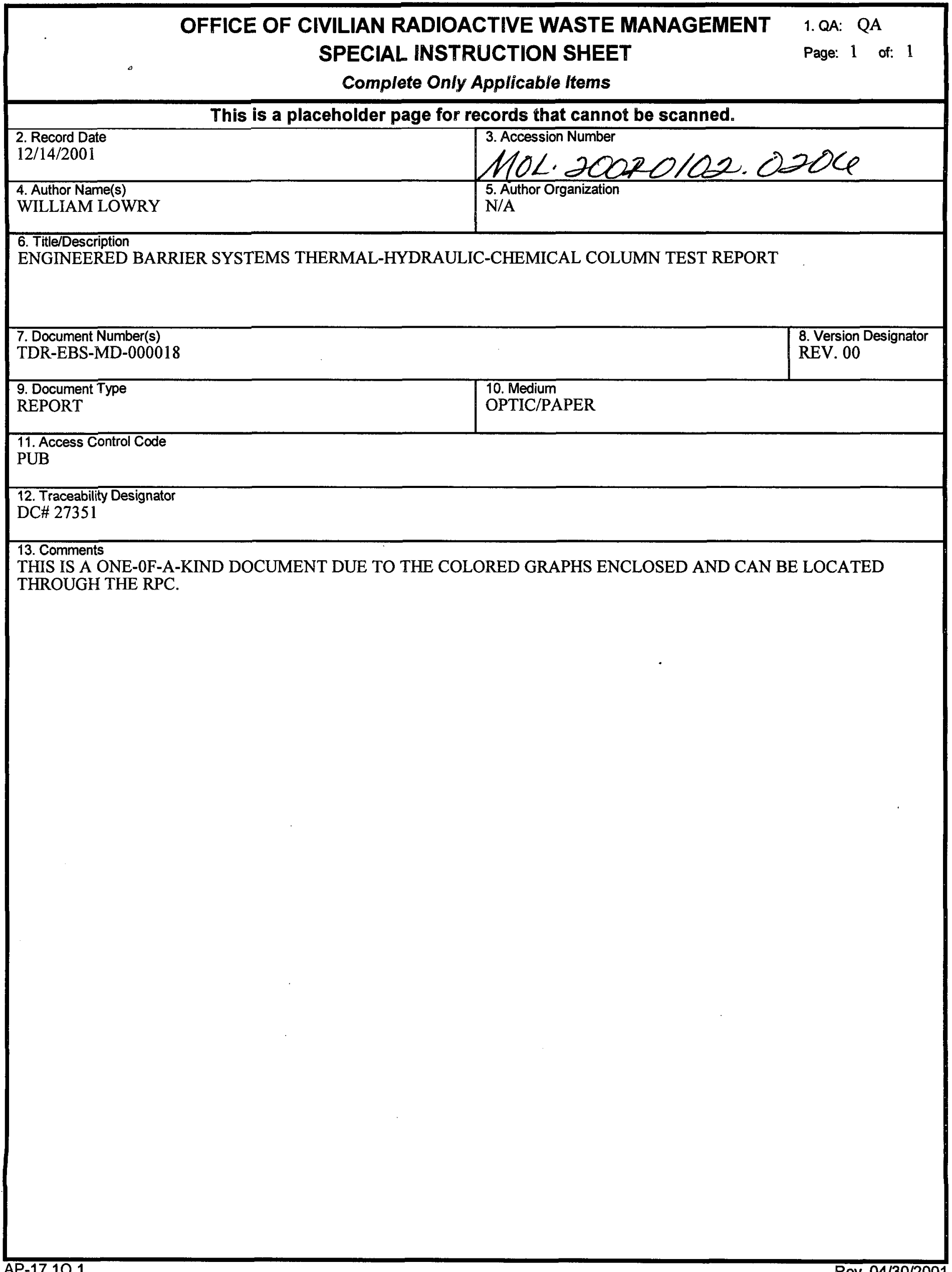


QA:QA

TDR-EBS-MD-000018 REV 00

December 2001

\section{Engineered Barrier Systems Thermal-Hydraulic-Chemical Column Test Report}

By

William E. Lowry

Prepared for:

U.S. Department of Energy

Yucca Mountain Site Characterization Office

P.O. Box 30307

North Las Vegas, Nevada 89036-0307

Prepared by:

Bechtel SAIC Company LLC

1180 Town Center Drive

Las Vegas, Nevada 89144

Under Contract Number

DE-AC08-01RW 12101 


\section{DISCLAIMER}

This report was prepared as an account of work sponsored by an agency of the United States Government. Neither the United States Government nor any agency thereof, nor any of their employees, nor any of their contractors, subcontractors or their employees, makes any warranty, express or implied or assumes any legal liability or responsibility for the accuracy, completeness, or any third party's use or the results of such use of any information, apparatus, product, or process disclosed, or represents that its use would not infringe privately owned rights. Reference herein to any specific commercial product, process, or service by trace name, trademark, manufacturer, or otherwise, does not necessarily constitute or imply its endorsement, recommendation, or favoring by the United States Government or any agency thereof or its contractors or subcontractors. The views and opinions of authors expressed herein do not necessarily state or reflect those of the United States Government or any agency thereof. 


\section{Engineered Barrier Systems Thermal-Hydraulic-Chemical Column Test Report}

Prepared by:

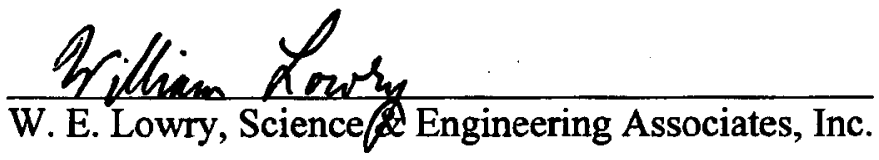

$$
\frac{12 / 13 / 01}{\text { Date }}
$$

Checked by:

Arimokan

James T. Kam, Yucca Mountain Project - Product Checking

Approved by:

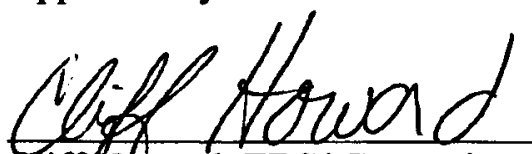

Cliff/Howard, EBS/ Geoengineering

Integration/ Implementation

$$
\frac{12 / 13 / 01}{\text { Date }}
$$

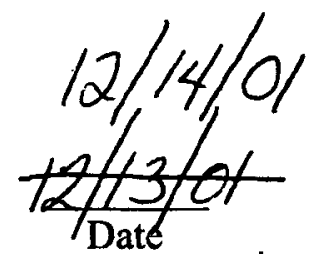

CH $12-14-01$ 
INTENTIONALLY BLANK PAGE 


\section{CONTENTS}

FIGURES

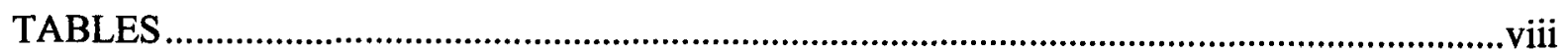

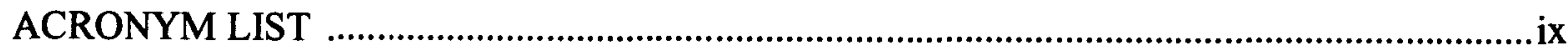

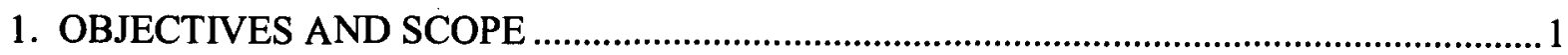

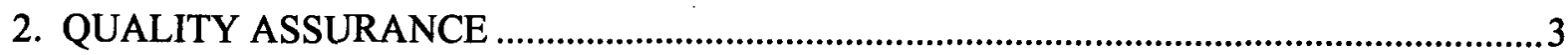

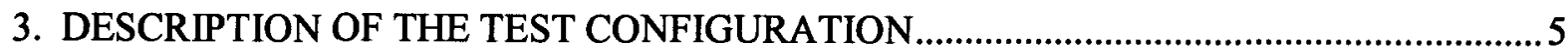

3.1 LESSONS LEARNED FROM COLUMN TESTS 1 AND 2 …........................................

3.1.1 Column Test 1 ...............................................................................................

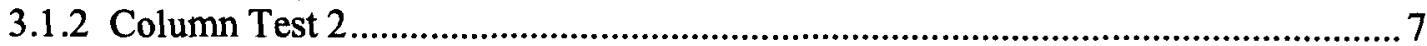

3.2 COLUMN TEST 3 DESIGN ....................................................................................

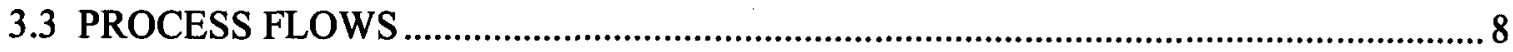

3.4 INSTRUMENTATION AND DATA ACQUISITION ..................................................

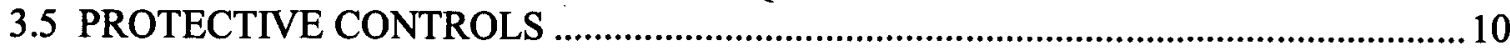

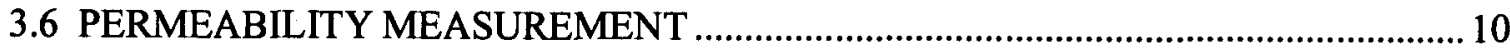

3.7 GEOCHEMICAL SAMPLING AND ANALYSIS ..................................................... 10

3.7.1 Fluid Sampling and Analysis .............................................................................. 11

3.7.2 Rock Sampling and Analysis ............................................................................11

3.7.3 Gas Sampling for $\mathrm{CO}_{2}$ Analysis ........................................................................13

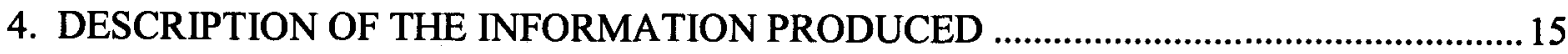

4.1 COLUMN TEST 3 CHRONOLOGY ……………….......................................... 15

4.2 LOGGED PROCESS DATA PLOTS ....................................................................

4.3 PERMEABILITY CALCULATIONS ...................................................................15

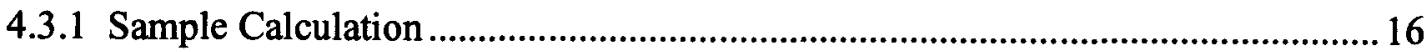

4.3.2 Air Permeability Results ................................................................................. 18

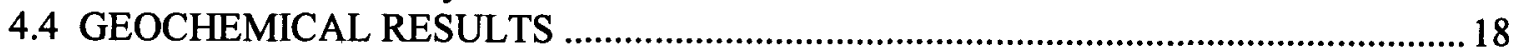

4.4.1 Column Fluid Cation and Anion Analyses .......................................................... 18

4.4.2 Petrographic Examination of Thin Sections ......................................................19

4.4.3 Mineralogical Analysis Results ....................................................................19

4.4.4 Column Solids Loading and Unloading Mass Results .......................................19

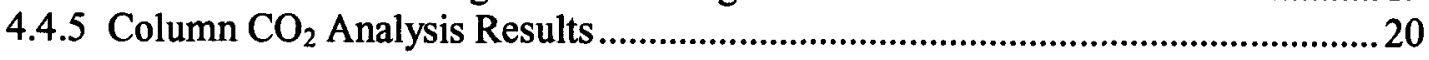

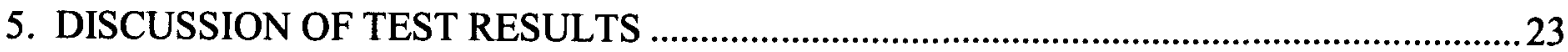

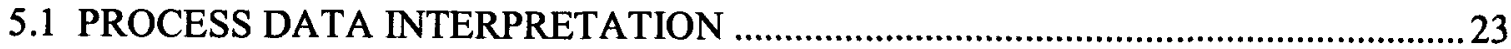

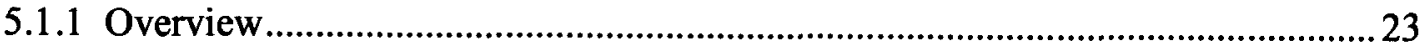

5.1.2 Heat Loss Calculations and Column Heat Balance ………………………….......2 23

5.1.3 Column Water Balance and Reflux ..............................................................2

5.2 SOLIDS MASS MOVEMENT …………........................................................25

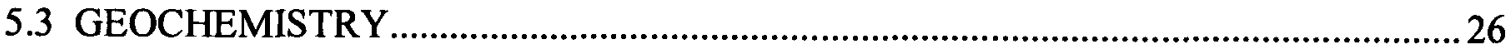

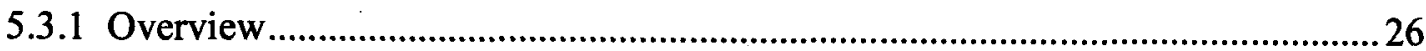

5.3.2 THC Column Fluids......................................................................................... 26

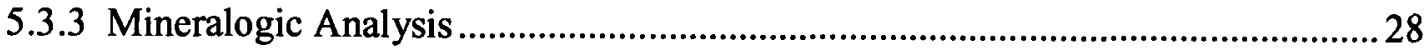

5.3.4 Column $\mathrm{CO}_{2}$ Partial Pressure..............................................................................30

5.4 RELEVANT THC STUDIES FROM CURRENT LITERATURE...................................31

5.4.1 Experimental Comparison with Rimstidt and Williamson .....................................31 


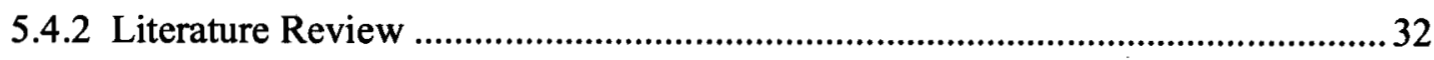

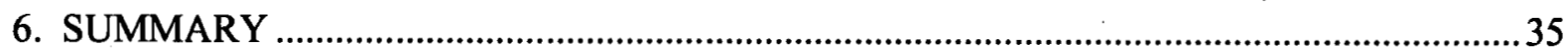

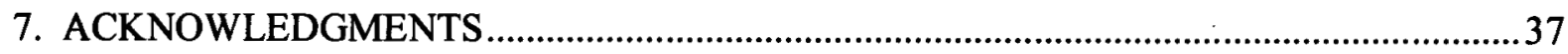

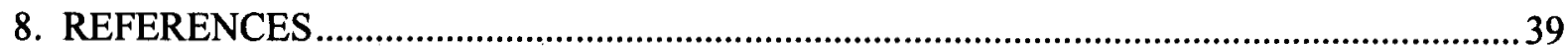

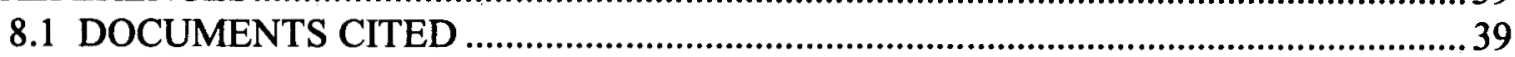

8.2 CODES, STANDARDS, REGULATIONS, AND PROCEDURES ...........................41

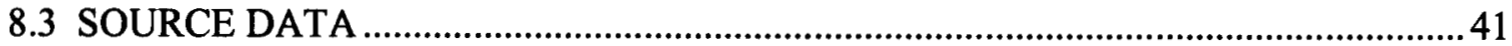

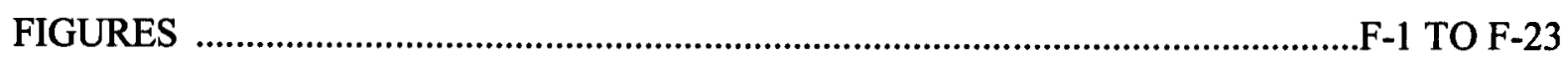

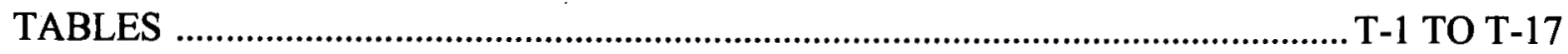

ATTACHMENT I: COLUMN TEST 3 CHRONOLOGY …............................................. I-1

ATTACHMENT II: PHOTOS OF CEMENTED TUFF FROM COLUMN TEST 3 ...............II-1 ATTACHMENT III: WATER LOSS DURING AIR SAMPLING OF COLUMN TEST 3 ...III-1 


\section{FIGURES}

Figure 1. General THC Column Test Configuration .............................................................. F-1

Figure 2. Column Construction Details ........................................................................... F-2

Figure 3. Column Assembly And Insulation Configuration ................................................. F-3

Figure 4. Cooling Disk ...............................................................................................

Figure 5. Column Process Flow Schematic ……………..................................................... F-5

Figure 6. Column Test 3 RTD And Lift Locations ............................................................... F-6

Figure 7. Column Test No. 3 Heater Input ........................................................................... F-7

Figure 8. Column Test No. 3 Cooling Cap Flow Measured As Volume .................................. F-7

Figure 9. Column Test No. 3 Cooling Cap Temperature ......................................................... F-8

Figure 10. Column Test No. 3 Injection Air Flow .................................................................. F-8

Figure 11. Column Test No. 3 Water Supply And Condensate Collection Scales .................... F-9

Figure 12. Column Test No. 3 Column Temperature (Bottom Half) .......................................... F-9

Figure 13. Column Test No. 3 Column Temperature (Top Half) ............................................ F-10

Figure 14. Air Permeability Measurements Of Column Test No. 3 ………............................. F-11

Figure 15. Column Test No. 3 Anion Concentration With Total Alkalinity And $\mathrm{pH}$............. F-12

Figure 16. Column Test No. 3 Anion Concentration With $\mathrm{pH}$.............................................. F-12

Figure 17. Column Test No. 3 Cation Concentration With pH ................................................ F-13

Figure 18. Column Test No. 3 Cation Concentration With pH .............................................. F-13

Figure 19. Reaction Rims Along Grain Boundaries, Samples from Lift 1

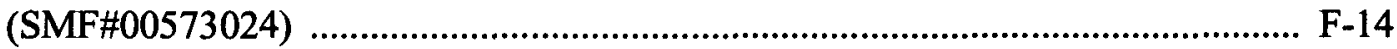

Figure 20. Secondary-Minerals In Sample From Lift 1 (SMF\#00573024) ............................ F-15

Figure 21. Cemented Rock Mass, Lift 1 ........................................................................ F-16

Figure 22. Column Test 3 Cooling Cap Heat Removal .......................................................... F-17

Figure 23. Column Test 3 Percent Heat Removal .............................................................. F-17

Figure 24. Column Water Mass Flow Rates And Estimated Mass Reflux Rate ....................... F-18

Figure 25. Net Change In Lift Mass .............................................................................. F-19

Figure 26. Column Bottom With Cemented Tuff .......................................................... F-20

Figure 27. Column Solution pH Correlated With Process Events ............................................ F-21

Figure 28. Secondary-Electron Image of Amorphous Silica Deposited in Ball-Bearing Layer Near Base Of Column ............................................................................. F-22

Figure 29. Secondary-Electron Image of Vitreous Amorphous Silica Coating on Crushed-Tuff Particle F-23

Photo II-1. Column Bottom With Cemented Tuff, Upper Ball Bearing Layer Exposed ............II-2

Photo II-2. Column Bottom With Cemented Tuff Above Ball Bearing Layer ...........................II-3

Photo II-3. Cemented Rock Mass From Lift 1 ...................................................................I-4

Photo II-4. Close-Up Of Cemented Rock Mass From Lift 1 .................................................... II-5 


\section{FIGURES (Continued)}

Photo II-5. Close-Up Of Column Bottom, Two Ball Bearing Layers Exposed

Photo II-6. Column Bottom with Cemented Tuff, Cemented Tuff and Ball Bearing 


\section{TABLES}

Table 1. Column Test 3 Chronology

Table 2. EBS Column Test 3 Instrument Specifications $\mathrm{T}-1$

Table 3. Samples Provided For Petrographic Analysis T-5

Table 4. Mineralogic Analysis Sample Descriptions

Table 5. EBS Column Test No. 3 Permeability Pretest Performed On 5/10/00 T-6

Table 6. EBS Column Test No. 3 Permeability Post Test Performed On 1/25/01 T-7

Table 7. Cation Analysis Of Column Fluid T-7

Table 8. Anion Analysis Of Column Fluid T-8

Table 9. pH Measurement Results From Column Test No. 3 Taken At Room Temperature .T-12 Table 10. pH Measurement results form Column Test No. 3 (To be Used Non-Q Data

Only Because Measured Values Fell Above Calibration Curve Of Instrument) .... T-13

Table 11. Quantitative XRD Mineralogy of EBS Thermal/Hydraulic/Chemical Column

Test No. 3 Samples (Weight Percent) $\mathrm{T}-14$

Table 12. Tuff Loading For Column Test No. 3 $\mathrm{T}-15$

Table 13. Column Test $\mathrm{CO}_{2}$ Analysis $\mathrm{T}-16$

Table 14. Operational Parameters and Methods used to Examine Experimental of Compositional Variables For VTGE and Column Test 3 $\mathrm{T}-17$

Table I-1. Column Test 3 Chronology $\mathrm{I}-2$

Table I-2. CT3 Heated Chronology

Plot III-1. Water Loss During Column Air Sampling On September 20, 2000, CTA-SCA1...III-2 Plot III-2. Water Loss During Column Air Sampling On October 5, 2000, CTA-SCA1........III-2 Plot III-3. Water Loss During Column Air Sampling On October 6, 2000, CTA-SCA1 ........III-3 Plot III-4. Water Loss During Column Air Sampling On December 6, 2000, CTA-SCA-1....III-3 Plot III-5. Water Loss During Column Air Sampling On December 18, 2000, CTA-SCA1 ...III-4 Plot III-6. Water Loss During Column Air Sampling On December 19, 2000, CTA-SCA1 ...III-4 Plot III-7. Water Loss During Column Air Sampling On January 6, 2001, CTA-SCA1 ........III-5 Plot III-8. Water Loss During Column Air Sampling On January 9, 2001, CTA-SCA1 ........III-5 Plot III-9. Water Loss During Column Air Sampling On January 10, 2001, CTA-SCA1......III-6 


\section{ACRONYM LIST}

$\begin{array}{ll}\text { ADEM } & \text { Automated Digital Electron Microscope } \\ \text { AP } & \text { Air Permeability } \\ \text { AMR } & \text { Analysis and Modeling Report } \\ \text { CRWMS M\&O } & \text { Office of Civilian Radioactive Waste Management } \\ \text { DAS } & \text { Data Acquisition System } \\ \text { DOE } & \text { U.S. Department of Energy } \\ \text { DP } & \text { Development Plan } \\ \text { EBS } & \text { Engineered Barrier System } \\ \text { FWP } & \text { Field Work Plan } \\ \text { IC } & \text { Ion Chromatography } \\ \text { ICP-AES } & \text { Inductively Coupled Plasma Atomic Emission Spectroscopy } \\ \text { IOC } & \text { Interoffice Correspondence } \\ \text { PMR } & \text { Process Modeling Report } \\ \text { RTD } & \text { Resistance Temperature Detector } \\ \text { QA } & \text { Quality Assurance } \\ \text { QARD } & \text { Quality Assurance Requirements and Description } \\ \text { QXRD } & \text { Quanitative X-Ray Diffraction } \\ \text { TCO } & \text { Test Coordination Office } \\ \text { THC } & \text { Thermal Hydraulic Chemical } \\ \text { YMP } & \text { Yucca Mountain Project } \\ \text { XRD } & \text { X-Ray Diffraction } \\ \text { SEM } & \text { Scanning-Electron Microscope } \\ \text { VTGE } & \text { Vertical Thermal Gradient Experiment } \\ \text { C-PVC } & \text { Chlorinated Polyvinyl Chloride } \\ \text { SMF } & \text { Sample Management Facility }\end{array}$




\section{OBJECTIVES AND SCOPE}

The Engineered Barrier System (EBS) Thermal-Hydraulic-Chemical (THC) Column Tests provide data needed for model validation. The EBS Degradation, Flow, and Transport Process Modeling Report (PMR) will be based on supporting models for in-drift THC coupled processes, and the in-drift physical and chemical environment. These models describe the complex chemical interaction of EBS materials, including granular materials, with the thermal and hydrologic conditions that will be present in the repository emplacement drifts. Of particular interest are the coupled processes that result in mineral and salt dissolution/precipitation in the EBS environment. Test data are needed for thermal, hydrologic, and geochemical model validation and to support selection of introduced materials (CRWMS M\&O 1999c). These column tests evaluated granular crushed tuff as potential invert ballast or backfill material, under accelerated thermal and hydrologic environments,

The objectives of the THC column testing are to:

1. Characterize THC coupled processes that could affect performance of EBS components, particularly the magnitude of permeability reduction (increases or decreases), the nature of minerals produced, and chemical fractionation (i.e., concentrative separation of salts and minerals due to boiling-point elevation).

2. Generate data for validating THC predictive models that will support the EBS Degradation, Flow, and Transport PMR, Rev. 01.

The scope of this report is to document the column experiments conducted and includes:

- The as-built configuration of the experiments.

- The test chronology.

- Operating conditions for the duration of the experiments.

- Initial and post-test crushed-tuff mass distributions in the column.

- The evolving chemical composition (including $\mathrm{pH}$ ) of the solution at the bottom of the column.

- Observations on the redistribution of solids in the column, including petrographic analysis of crushed-tuff thin sections, X-Ray Diffraction (XRD), and Scanning Electron Microscope (SEM) analyses of secondary minerals deposited at the column's lowest lift.

It should be noted that three separate column experiments were conducted. Column Test 1 was started and completed in December 1999 (terminated prematurely due to a water seal failure at the bottom of the column); Column Test 2 ran from January 6, 2000 to February 4, 2000 (to completion); and Column Test 3 operated from September 18, 2000 to January 12, 2001. Although the thermal and hydraulic performance the first two tests, Column Tests 1 and 2, is 
considered representative of the Yucca Mountain material, the compositional information from these two tests is suspect because of contaminated material identified in the crushed tuff at the completion of Column Test 2 (Paces and Peterman 2000). The form of the contamination was determined to be non-Yucca Mountain geologic media and asphalt particles, possibly introduced when the material was crushed off-site. A third test (Column Test 3) was conducted with uncontaminated media, incorporating improvements derived from the experience of the first two tests, and will be the major emphasis of this report. Column Tests 1 and 2 will only be referenced for the lessons-learned during those tests, and chemistry data from constant head water supply samples taken during tests 1 and 2 are used as baseline data (see Section 5.3.2.1). 


\section{QUALITY ASSURANCE}

The QAP-2-0 Activity Evaluation for the EBS Testing Program (CRWMS M\&O 1999a), concludes that the testing program is quality affecting. The QAP-2-0 Activity Evaluation also revealed that the EBS Testing Program affects items on the Q-List (YMP 1998) and is therefore subject to the Quality Assurance Requirements and Description (QARD) (DOE 2000). QAP-2-0 Activity Evaluation and Q-List (YMP 1998) were in effect for Column Tests 1 and 2. TWP-EBS-MD-000009, Rev. 03 (BSC 2001) and Q-List (YMP 2000a) were in effect for Column Test 3.

Key quality assurance features of this testing program include:

- The technical needs for this testing are documented in the Request for Laboratory Bench-Scale Column Test Data for Engineered Barrier System Thermal, Hydrological, Chemical Model Validation (CRWMS M\&O 1999b).

- The Development Plan, Development Plan (DP) for EBS THC Column Tests, TDP-EBS-ND-000003 Rev. 00 (CRWMS M\&O 1999c), describes the general development of this test, the test plan, quality assurance requirements, and data requirements.

- Planning guidance is provided by an (Interoffice Correspondence) (IOC) titled Planning Guidance for the EBS THC Column Test (Pye 1999).

- Programmatic documentation defines the execution plan, equipment requirements, and health and safety guidelines:

- Work Instruction \#TCO-WI-0043, R. 01 (CRWMS M\&O 2000)

- Details of the test configuration and records of the test execution are documented in scientific notebook numbers SN-M\&O-SCI-016-V1, SN-M\&O-SCI-016-V2, and SNM\&O-SCI-016-V3, EBS Column Test Field Notebooks, per procedure AP-SIII.1Q Scientific Notebooks (Lowry 2001 a; Lowry 2001b; Lowry 2001c).

- Available YMP procedures have been incorporated where appropriate. This includes the pH measurement procedure YMP-USGS-HP-23, R5 Collection and Field Analysis of Water Samples.

- All instruments were calibrated in the DOE Bechtel calibration lab or their calibration was checked by protocols documented in scientific notebooks SN-M\&O-SCI-016-V1 (Lowry 2001a), SN-M\&O-SCI-016-V2 (Lowry 2001b), and SN-M\&O-SCI-016-V3 (Lowry 2001c), EBS Column Test Field Notebooks, prior to test execution.

- The software utilized during Column Tests 1, 2, and 3 was MS Excel V. 97, SR-2 for performing calculations and making plots and MS Photoeditor V. 3.0 for cropping and 
pasting images. These software uses are exempt from verification as per AP-SI.1Q Software Management, Section 2.1.

- Data acquisition and management is performed by the Test Coordination Office (TCO). Control of electronic data was performed under procedure AP-SV.1Q, Control of the Electronic Management of Information. The Technical Work Plan (BSC 2001) outlines the procedures that were followed in order to comply with AP-SV.1Q. Electronic data were stored on writable CDs that were clearly labeled and dated, thus achieving data security and integrity. Electronic data were reviewed and verified prior to being submitted to the TDMS.

- Protocols were developed and documented in the scientific notebook for unique circumstances not covered by established procedures. Protocols were documented in the scientific notebook for the water flowmeter calibration check and the column air permeability measurement. 


\section{DESCRIPTION OF THE TEST CONFIGURATION}

The THC column experiment quantifies the redistribution of minerals in granular media by reflux of water in a heated environment. A vertical column is closed on the bottom and vented at the top (see Figure 1). A heater is installed in the bottom, and the column filled with crushed Topopah Spring tuff. Deionized water is introduced near the bottom from a reservoir, which maintains the liquid level constant so that the bottom $10 \%$ (approximate) of the column is saturated. The column is boiled vigorously, and a cooled cap at the top of the column induces condensation. Condensate percolates downward through the unsaturated column as reflux. A small amount of air is injected in the bottom of the column to prevent oxygen depletion in the column gas. Escaping water vapor (through the steam vent) is collected at the top, condensed, and measured for mass balance. Probes at several elevations in the column measure temperature, and water samples are obtained from both the saturated and unsaturated regions of the column. An air permeability survey is conducted pre-test, and after the heated test. Ports in the side of the column allow sampling of fluids and access for temperature probes and permeability testing. At several times during the execution of the test, air samples are drawn from the column fill, ambient air, and the column vent line for analysis of carbon dioxide content. This data aids in the definition of the geochemical conditions of the column fluids.

The general test sequence is as follows:

1. Prepare water, granular material, and test hardware in the appropriate configuration.

2. Fill the test column with granular material.

3. Measure the baseline air permeability distribution in the column.

4. Introduce water to establish the desired water level.

5. Apply heat to the bottom of the column.

6. Adjust thermal power input to achieve prescribed thermal conditions.

7. Measure temperature and obtain water samples periodically.

8. Periodically sample the column, ambient, and steam vent air for carbon dioxide analysis.

9. Run at a constant thermal flux for a prescribed period or until endpoint conditions are achieved.

10. Perform a post-test permeability survey on the dry column fill.

11. Obtain granular samples from the column for analysis of secondary mineral precipitates. 
The primary measurements to diagnose the column operation include:

- Heat input

- Temperature distribution in the granular column material

- Water added to the column

- Water vapor loss rate

- Vertical air permeability distribution of the dry granular fill before and after the test

- Water composition in the saturated zone at various times during the test duration in the saturated zone

- Carbon dioxide composition of the column air and the estimated partial pressure of the air in the column

- Mass loss or gain of crushed tuff in the column at various heights

- Distribution of minerals and salts in the granular media.

The initial column tests operated in the Atlas High Bay at the U.S. Department of Energy (DOE) North Las Vegas facility on Losee Road. The experiment was relocated to building B-4 at the DOE facility prior to execution of the third column test.

\subsection{LESSONS-LEARNED FROM COLUMN TESTS 1 AND 2}

This test design was fashioned after a previous experimental program conducted by Rimstidt and Williamson (1991), where column reflux experiments were conducted using several granular materials, including volcanic tuff (features of the Rimstidt and Williamson test are compared in greater detail with this column test in Section 5.4.1). In those tests, a PVC column was filled with the granular material and heat applied to the bottom. The design of the current tests capitalized on the features and experience of the Rimstidt and Williamson series, with changes to facilitate experiment observation, condition controls, and process diagnostics. For example, the first column test (identified as Column Test 1) incorporated a clear polycarbonate column housing, intended to aid visualization of the reflux process. While the polycarbonate could withstand the boiling temperatures in plain water, the elevated $\mathrm{pH}$ experienced in the boiling zone induced failure of the heater seal and resulted in inadvertent termination of the test. The subsequent test, Column Test 2, utilized a chlorinated polyvinyl chloride column housing, and operated for the desired duration (although contamination of the fill material was diagnosed and led to rerunning of the test). Each of these tests contributed to improvements in the design of the test apparatus, which exceeded operating duration expectations in column Test 3. 


\subsubsection{Column Test 1}

The initial test assembly was completed in early December 1999. This test was conducted using a clear polycarbonate cylinder to contain the tuff. The system operated at nominal power until an unintentional shutdown due to a leak in the column on $12 / 28 / 99$. Inspection of the column showed that the polycarbonate degraded, suspected due to a combination of fractures and erosion from the high pH water at the bottom of the column (Lowry 2001a, pp 44-45). The test was terminated and a suitable replacement for the polycarbonate column material was identified.

\subsubsection{Column Test 2}

A new column was fabricated of chlorinated polyvinyl chloride (C-PVC) and Column Test 2 was started on January 6, 2000 (Lowry 2001a, pp 56-110). This test operated for 696 hours until an intentional shutdown on February 4, 2000. During the petrographic analysis of the post-test material, it was discovered that the tuff grains used in Column Tests 1 and 2 had been contaminated with asphalt grains and other non-Yucca Mountain material during the crushing process (Paces and Peterman 2000). Additional changes were made to the column design following Test 2. During the column unloading process, it was discovered that the C-PVC had experienced some degradation caused by heat (although it had not failed). It was determined that a more resilient material would be used in Column Test 3 as a container.

\subsection{COLUMN TEST 3 DESIGN}

The crushed tuff was contained by a $14.69 \mathrm{~cm}$ inside diameter, $98.66 \mathrm{~cm}$ tall type 304 stainless steel cylinder (Figure 2). The cylinder consisted of upper and lower sections connected by a band clamp seal. A type 316L stainless steel plate was welded in to form the bottom of the lower cylinder to contain the crushed tuff and the column liquid. An electrical resistance heating element was attached to the plate's underside and served as the column heat source. Because of the large surface area represented, the inside surfaces of the upper and lower cylinders were Teflon coated to minimize chemical interactions between the stainless steel and the column fluids in the region of the unsaturated tuff, where the reaction chemistry was considered the most sensitive to potential contamination. Figure 2 shows the locations of fluid sampling ports, temperature measurement ports and other access ports.

A type 303 stainless steel cooling unit was inserted at the top of the cylinder (see Figure 3 ). The disk was fabricated with cooling channels to serve as the heat exchanger that removed heat from the top of the column. Chilled water maintained at a temperature of about $15{ }^{\circ} \mathrm{C}$, provided by an external refrigerator unit, recirculated in the cooling cap to remove the heat transferred by the water vapor from the bottom of the column (see Figure 4).

At the bottom of the column, a $2.2 \mathrm{~cm}$ layer of $7.94 \mathrm{~mm}$ diameter stainless steel ball bearings separated the heater plate and crushed tuff (Figure 3). The water supply line entered in this space. The layer of ball bearings served as a water supply plenum and enhanced the transfer of heat from the bottom plate to the water. Since their role was to enhance heat transfer in the boiling zone, the ball bearings were not coated with Teflon (which would have inhibited conductive heat transfer). At the top of the column, an air space existed between the top of the 
crushed tuff and the cooling disk. The steam vent and column vapor pressure measurement were located in this space. During the air permeability test, these upper and lower spaces also served as low-pressure and high-pressure air plenums, respectively.

The column was filled with crushed tuff in lifts, separated by nylon screens. The screened lifts were designed to minimize mechanical redistribution of the tuff from one lift to the other, such that the quantified mass changes in each lift could be attributed to transport in the reflux solution. The column was supported by a fiberglass-impregnated phenolic structure that held it vertical. The support rested on a calcium silicate insulating base.

The column sides were insulated with a $15-\mathrm{cm}$ thick phenolic foam pipe insulation, configured in semi-cylindrical halves. The front half of the insulation could be removed to allow for fluid sampling and visual inspection. The insulation's thermal conductivity was specified by the manufacturer as $0.019 \mathrm{~W} /(\mathrm{m}-\mathrm{K})$ (Belform 2000). The insulation extended above the top of the column encompassing the cooling cap, and its associated tubes and hardware. A polystyrene lid enclosed this from above.

The Column Test No. 3 assembly is depicted in Figure 5, showing the complete assembly, as well as the assembly with insulation removed.

\subsection{PROCESS FLOWS}

The process flows consisted of five main systems: water supply, steam vent, heating, heat removal, and ambient air supply systems. These are all depicted in Figure 5.

The water supply system replenished water lost during operation with deionized water. This system consisted of a water supply tank, pump, metering valve, constant head reservoir, check valve, and degassing cylinder. Deionized filtered water was pumped from the nominal covered supply tank to the constant head reservoir. The constant head reservoir maintained a $10 \mathrm{~cm}$ height of liquid water in the column (measured from the top of the heating plate). A check valve prevented reverse flow from the column back to the constant head reservoir. From the check valve and constant head reservoir assembly, water traveled to a polycarbonate degassing cylinder. The degassing cylinder was located inside the insulation, contacting the column so that the water was near the column temperature. The elevated temperature reduced the solubility of atmospheric gases in the water, minimizing the amount of dissolved gases in the supply water. A vent line allowed expelled gas to escape the degassing cylinder. The degassed supply water then entered the column directly above the heating disk in the ball bearing region.

The vent system allowed the column to operate at ambient pressure by venting air and water vapor during the course of the experiment. The vent port was located at the top of the column in the space between the cooling disk and the crushed tuff. The water vapor that escaped through the vent line passed through a condenser and was collected as liquid water in the covered condensate collection tank. The condenser was cooled by chilled water drawn from the chilled water reservoir tank. 
The heating system applied heat at the bottom of the column at a rate of nominally $400 \mathrm{~W}$. This was achieved by means of an electric heating element mounted on the underside of the heating plate. A variable transformer regulated the power input to the desired level.

The cooling system created a condensation heat sink at the top of the column, sustaining the thermal gradient that drove the steam upward. The cooling disk temperature was maintained by circulating chilled water across its non-process side. The cooling disk was maintained nominally at $25^{\circ} \mathrm{C}$. With the heater plate producing boiling conditions at the bottom of the column, the thermal gradient over the height of the column was approximately $78{ }^{\circ} \mathrm{C}$ per meter, with almost all of the gradient occurring in the top several centimeters near the cooling plate.

The ambient air supply system injected air to the crushed tuff at a rate calculated to provide sufficient oxygen to support reactions in the column material (the column would have been purged of oxygen by water vapor if air was not purposefully injected). The air was injected through a stainless steel tube that entered the column above the saturated zone at sampling port number 2 (see Figure 2). The air was injected nominally at $16 \mathrm{cc} / \mathrm{min}$ at room temperature. The concentration of $\mathrm{CO}_{2}$ in the injected air was expected to be a normal ambient value of 400 to 500 ppm.

\subsection{INSTRUMENTATION AND DATA ACQUISITION}

Data acquisition was achieved with a Geomation data logger, managed by the TCO. Monitored processes included crushed-tuff temperature, amount of water entering and exiting the column, heat input at the bottom of column, heat removal at top of column, cooling cap temperature, internal column gas pressure, and flow rate of the ambient air supply.

Crushed-tuff temperature was monitored at several positions along the length of the column by resistance temperature detector (RTD) sensors (see Figures 1 and 2). Several of the temperature sensors were removed or relocated during the course of the experiment due to sensor failure, and Table 1 lists the relationships between sensors and the dates that they were in certain positions. A diagram of RTD positions in the final configuration is provided in Figure 6 . The bottom sensor was located directly above the heating plate in the ball bearing region. The top sensor was located in the air plenum between the top of the crushed tuff and the cooling disk. The sensors, ceramic RTD elements, were inserted in Teflon-coated stainless steel thermowells (the ceramic RTD elements could not be exposed directly to water).

The amount of water entering the column through the constant head system was monitored by a scale under the water supply tank, and water exiting the column was monitored by a scale under the condensate collection tank (see Figure 5).

The heat input rate at the bottom of the column was monitored by a transducer mounted in series with the heating circuit. The heat removal rate at the top of the column was determined by measuring the cooling cap chilled water flow rate and resulting cooling water temperature rise. The inlet and outlet cooling cap water temperatures were monitored by means of submersed thermowells and RTD sensors. The water flow rate was determined by use of a turbine flow meter mounted in line with the cooling water. The cooling cap temperature was monitored by 
use of an RTD inserted in a mounting screw in the center of the cooling cap. This RTD is labeled as RTD11 in Figure 5.

The internal column pressure was measured in the space between the crushed tuff and the cooling disk by a barometric pressure transducer, which is labeled as PRESS1 in Figure 5.

The ambient air injection rate was monitored by an inline air flow meter (Figure 5).

Instrument identifiers, descriptions, and specifications are listed in Table 2.

\subsection{PROTECTIVE CONTROLS}

The column test system was protected against thermal and pressure excursions that could potentially damage the components or pose safety hazards. A combination of temperature interlocks, pressure interlocks, and pressure relief valves were used.

Temperature was sensed by thermocouples in the heater assembly at the bottom of the column, the water space above the heater assembly, and the cooling cap at the top. These thermocouples are non-Q instruments separate from the RTD temperature elements used to diagnose process operation. Setpoints were selected for each of these measurements that would de-energize the heater if exceeded, protecting the column from overtemperatures due to loss of make-up water and a failure in the heat removal capability of the cooling cap. A pressure switch connected to the column water inlet port at the bottom was set to de-energize the heater if an overpressure condition existed at the bottom of the column, and mechanical relief valves connected to both the bottom and top of the column provided redundant protection at these locations.

\subsection{PERMEABILITY MEASUREMENT}

Air permeability (AP) measurements were conducted to evaluate the impact of mineral redistribution on the tuff flow properties. To conduct the permeability measurement, ambient air is pumped into the bottom of the column and allowed to vent out the top (the column must be dry). The sampling ports on the side of the column are then used (in pairs) to measure the discrete pressure drop at that specific height of the column (see Figure 2). Details of the measurement and the results are described in Section 4.3.

\subsection{GEOCHEMICAL SAMPLING AND ANALYSIS}

The overall objectives for the geochemical examination of the THC column tests were to provide data that describe the geochemical processes affecting the redistribution of mineral matter within the experimental configuration. From the geochemical perspective, the test configuration was analogous to a vapor dominated hydrothermal system. The heat introduced into the bottom of the column produced a boiling zone in the constant head region at the bottom of the column. Water vapor liberated from this boiling zone traveled upward through the granular fill material in the column. Condensation of this vapor, principally at the top of the column where the vapor contacts the surfaces of the cooling disk, resulted in production of liquid water that was essentially devoid of dissolved solids. This condensed water is corrosive to the rock fill of the 
column and as it passes back down the column toward the boiling zone, it will dissolve mineral matter. As this fluid continuously reached the boiling zone at the base of the column over the life of the experiment, the concentration of solutes in the boiling zone increased. This process of redistribution and concentration of dissolved matter in the boiling is one probable mechanism for causing the saturation of various minerals in the boiling zone. During the test, the precipitation of certain minerals occurred in the boiling zone, a process referred to as secondary mineralization. In addition to dissolved solids, smaller undissoved particles were transported in the reflux solution to the boiling zone.

The material used in this experiment is from the crystal-poor middle nonlithophysal zone of Topopah Spring Tuff (Tptpmn), which was removed from Alcove 8 (Sample Management Facility Number SPC00562011 (YMP 2000b). Based on previous dissolution and precipitation experiments performed on Topopah Spring and other Yucca Mountain Tuffs, it was expected that various silica minerals and one or more calcium carbonate minerals would precipitate as secondary minerals. The sampling results and analyses of the column fluids and rock materials were intended to provide a quantitative assessment of the secondary mineral assemblage precipitated at or near the boiling zone, the gross chemistry of the fluids precipitating these secondary minerals, and a qualitative assessment of which mineral phases within the tuff are most susceptible to dissolution by the condensed water.

\subsubsection{Fluid Sampling and Analysis}

Sampling of the column fluids monitored the evolution of the column chemistry over the course of the experiment run time. All samples were drawn from sampling port number 1 (see Figure 2), located in the boiling zone, at regular intervals over the life of the test via a syringe. These fluid samples were analyzed for a variety of major and minor cations by an inductively coupled plasma atomic emission spectroscopy (ICP-AES) at Los Alamos National Laboratory. The analysis list for cations included: $\mathrm{Na}, \mathrm{K}, \mathrm{Ca}, \mathrm{Fe}, \mathrm{Mn}, \mathrm{Mg}, \mathrm{Si}$, and $\mathrm{Al}$. The samples were also analyzed for various anions $\left(\mathrm{Cl}, \mathrm{Br}, \mathrm{SO}_{4}, \mathrm{NO}_{3}, \mathrm{PO}_{4}\right.$, and $\left.\mathrm{F}\right)$ by ion chromatography (IC), and total alkalinity. The solution $\mathrm{pH}$ was also measured whenever a sample was collected. Before $\mathrm{pH}$ measurements were taken, the samples were allowed to cool down to room temperature. The $\mathrm{pH}$ measurements were conducted in an inert atmosphere to prevent an interaction of the sample with any atmospheric gasses, such as $\mathrm{CO}_{2}$, that might alter the observed $\mathrm{pH}$. This was accomplished through the use of a $\mathrm{pH}$ measurement cell designed to prevent the sample from coming into contact with the ambient atmosphere from the time of collection throughout the measurement, and provided an inert gas atmosphere (argon) in the head space above the sample.

\subsubsection{Rock Sampling and Analysis}

An aliquot of crushed tuff was obtained from sample SPC00562011 (crystal-poor middle nonlithophysal zone of Topopah Spring Tuff) for the purposes of filling the column. Prior to use in the column, this aliquot was washed with tap water, rinsed with deionized water, and oven dried to obtain a consistent basis for the initial mass determinations. The crushed tuff was loaded into the column in ten separate lifts, with the actual mass of rock determined for each lift. Figure 6 shows the approximate depth of each lift. This was done to allow a quantitative assessment of the change in rock mass as a function of vertical position within the column to be 
determined upon completion of the experiment. Following the experiment, each lift was removed from the column and its mass determined again for comparison with the starting mass. These results are reported in Section 4.4.4. Column unloading was performed by removing the lifts one at a time with use of a shop vacuum and a 5-gallon container used to capture the material. Representative samples of the rock materials were recovered from each of the lifts. For those lifts that remained loose granular material, the samples were obtained using a riffle splitter. Those samples that were well cemented as a result of significant secondary mineralization were sampled using a hammer and chisel.

\subsubsection{Petrographic Analysis of Thin Section Mounts}

Grain mount thin sections were prepared for those samples that remained granular, and traditional whole rock thin sections were prepared for those samples that were well cemented. Petrographic analysis of the thin sections was carried out using a conventional light microscope and optical means to identify the cementing phases and the cement characteristics, including thickness and any zoning that may be evident. Petrographic analyses were performed by Peterman (2001). A list of the samples used in the analyses with their descriptions can be found in Table 3. A discussion of the petrography is found in Section 4.4.2, and a complete set of images obtained by Peterman is provided in Attachment II.

\subsubsection{Quantitative and Semi-Quantitative Mineralogic Analysis}

Column materials, including cement samples from the column, were analyzed for mineral and elemental composition and for evidence of mineral dissolution and secondary-mineral deposition (DTN\# LA0107SL831222.001; DTN\# LA0108SL831225.001; DTN\# LA0110SL831225.001). The materials analyzed for evidence of mineralogic or textural change are listed and described in Table 4. Analyzed samples include examples of the crushed-tuff starting material, crushed tuff retrieved from the top of the column after the test, and deposits of cementing material from the bottom of the column. Crushed-tuff samples provided for mineralogic analysis consisted of approximately one-half kilogram each of material from Lifts 1, 2, 5, 8, and 10.

Methods used in the analyses were stereomicroscopy and ultraviolet-light examination, quantitative X-ray diffraction analysis (quantitative XRD or QXRD), and semi-quantitative scanning electron microscopy (SEM). A stereomicroscope was used for general examination of the crushed-tuff starting material, the post-test materials from various lifts, and the secondary cement from the lower part of the column. The selection of certain crushed-tuff fragments for scanning-electron microscopic examination was aided by stereomicroscopic identification of a variety of textural features. It was desirable that the fragments examined by SEM include examples of natural fracture surfaces and mechanically broken surfaces and rocks with a greater or lesser degree of vapor-phase alteration. In this way, the possible effects of pre-existing heterogeneity could be investigated.

Test materials were observed under short-wavelength ultraviolet illumination. Calcite commonly fluoresces under ultraviolet illumination, allowing the visual identification of very small quantities of this mineral. Amorphous silica deposited in silicic, volcanic-rock environments commonly fluoresces due to its affinity for uranyl ions (Zielinski 1980; Zielinski 
1982). Fluorescence has been observed in amorphous silica deposited during the Single-Heater Test (Harrington 1998).

Multiple aliquots of the crushed-tuff starter material and the crushed tuff retrieved from the uppermost lift (Lift 10) were prepared with the use of a riffle splitter. Five aliquots of each material were analyzed for mineral content to assess the homogeneity of the crushed-tuff starter stock and to test for detectable mineralogic changes resulting from the hydrothermal test. Aliquots from two samples of secondary cementing material deposited near the base of the column during the test were also analyzed.

Samples for XRD analyses were mixed with an internal standard of $1.0 \mu \mathrm{m}$ corundum in a ratio of approximately $80 \%$ sample to $20 \%$ corundum. The mixtures were ground for approximately 10 minutes under acetone in a Brinkmann automated grinder to reduce the particle size and to homogenize the sample and internal standard. Samples were analyzed using a Siemens D-500 powder diffractometer.

The Automated Digital Electron Microscope (ADEM) scanning-electron microscopy system (SEM) was used to generate and examine images of crushed-tuff starting material, crushed tuff retrieved from specific lifts after the experiment was completed, and cementing material deposited during the test. An energy-dispersive x-ray analyzer integral to the system was used to obtain semi-quantitative spectra of elemental constituents.

The starter material used in the column test was washed before being loaded into the test column to remove fine particulates adhering to the surfaces of the crushed-tuff fragments. Samples of this washed material were not retained for characterization. The material supplied for mineralogic and textural characterization, reported here, was not washed although it originated from the same batch of crushed tuff. The consequences of this difference are possibly insignificant but quantitatively unknown. This issue was addressed by preparing a split sample from the original material (sample SPC00562011) in the same manner as the material used in this test. A comparison between the newly washed untested material and the results from the tested material is included in this report.

\subsubsection{Gas Sampling for $\mathrm{CO}_{2}$ Analysis}

To understand the geochemical conditions inside the column, knowledge of the partial pressure of gaseous carbon dioxide $\left(\mathrm{CO}_{2}\right)$ is needed. Even though air is injected in the bottom of the column, the air/vapor mixture is dominated by water vapor such that the vapor fraction of air (which includes $\mathrm{CO}_{2}$ ) is less than $1 \%$ of the total mixture. To quantify the $\mathrm{CO}_{2}$ partial pressure, the $\mathrm{CO}_{2}$ concentration in the air was measured directly, and the vapor fraction of the air in the presence of water vapor was estimated. The estimated vapor fraction, and calculated parameters that incorporate its value, are qualitative (non-Q) data only.

Air samples were collected from the room ambient air, the column itself, and the column vent line. All were collected in Tedlar bags (nominally 1 liter volume). Room air samples were obtained by expanding the sample bag in a vacuum box. Column gas samples were obtained by connecting port 6 of the column sampling port (see Figure 2), located $51.43 \mathrm{~cm}$ above the 
column heating plate, to a sampling train. The very slight overpressure that naturally existed in the column drove the air/water vapor mixture out of port 6 into the sampling train. Immediately after leaving the port 6 sampling fitting, the air/water vapor mixture entered a condensate collection chamber where the water vapor was allowed to condense. This chamber was not actively chilled and was located in contact with the column, so remained at a relatively high temperature (estimated at approximately $90^{\circ} \mathrm{C}$ ). The air sample exited this chamber, with most of the water vapor removed, and filled the Tedlar sample bag. Typically, 0.3 to 0.4 liters (estimated) of column air were collected for analysis. Because of the low flow rate of injected column air (nominally $16 \mathrm{cc} / \mathrm{min}$ ), the sample collection time was typically one to two hours. A small amount of condensed water (estimated at less than $1 \mathrm{cc}$ ) typically collected in the Tedlar sample bag. Steam vent line samples were obtained by connecting a sample bag directly to the steam vent, allowing the column overpressure to fill the bag.

The contents of the sample bag were then analyzed in a Columbus Instruments Model 180C nondispersive infrared gas analyzer. The manufacturer's stated accuracy for this instrument is, for the low range $\left(0 \%\right.$ to $1.0 \% \mathrm{CO}_{2}$ in air) $+1-0.01 \% \mathrm{CO}_{2}$, and for the high range $\left(0 \%\right.$ to $15.0 \% \mathrm{CO}_{2}$ in air) $+1-0.15 \% \mathrm{CO}_{2}$. This is a flow-through device that requires a steady flow of the sample gas through its analysis chamber to determine the $\mathrm{CO}_{2}$ fraction in the air. One to two minutes were typically required to obtain a steady indication. Prior to, and after, each sample bag analysis the gas analyzer was calibrated with a known gas standard from a qualified supplier. Sampling and calibration records are contained in SN-M\&O-SC1-016-V2 (Lowry 2001b, pp. 84-85, 136, 144, $149,150,151,167)$. 


\section{DESCRIPTION OF THE INFORMATION PRODUCED}

\subsection{COLUMN TEST 3 CHRONOLOGY}

A detailed chronology of Column Test 3 is provided in Table 1 and Attachment I. Column Test 3 assembly was finished in September 2000. The heater was energized on September 18, 2000 and the test continued to January 2001. In the early stages of the test the power level was adjusted to observe column operation and the resulting heating plate temperatures. Input power levels were modified to determine a sufficiently conservative heater temperature setpoint that would allow a high heat input (to maximize reflux rate). After evaluating input power as high as 475 watts (see Table 1), the lowermost temperature sensor (CT1-RTD08) indicated an excessive temperature rise (see Figure 13) and the power was reduced to 400 watts on 10/20/00 (see Table 1). The test experienced several power interruptions. These interruptions were due to a planned facility power shutdown, chiller system failure, and inadvertent loss of make-up water for a short period near the end of the test. Since the column fluid was not lost or exchanged during these power outages, they were not felt to have significantly degraded the test results.

The total heated operating time at test completion was 2357.8 hours (Lowry 2001c, p. 12). The test was stopped on January 12, 2001 when the column bottom temperature began to exceed the safety set point, causing the heater power to cycle on and off. This was interpreted as indicating significant accumulation of precipitates in the boiling zone (one of the test termination criteria) and the test was shut down. Column disassembly began on January 16, 2001 and the column material was unloaded on January 25, 2001.

\subsection{LOGGED PROCESS DATA PLOTS}

Test data for Column Test 3 are plotted in Figures 7-13. Data were collected at five-minute intervals (DTN\# MO0107EBSTHCT3.007) during the initial column start up and at various times when greater time resolution was desired, (i.e., during column heater restarts). The standard collection interval for the bulk of the test was once every hour. Process data were used to calculate heat loss from the cooling cap, water balance in the column, and determine the reflux rate relative to the water loss through the steam vent. Sections 5.1.2 and 5.1.3 outline these calculations.

\subsection{PERMEABILITY CALCULATIONS}

Air permeabilities of the column layers were measured by injecting a measured flow rate of air in the bottom of the column, allowing it to pass up through the crushed tuff and vent out the top of the column. For the post-test analysis, the column was dried by circulating ambient air through the tuff. Dryness was confirmed when the air exiting the column showed the same low relative humidity as that entering the column. The differential pressure was measured across each set of measurement ports, spaced 9.27-cm apart (Figure 2). Using a procedure based upon an ASTM standard method for air permeability determination of granular media (ASTM 1998), the coefficient of permeability was computed using the following equation: 


$$
k=\frac{2 Q_{e} P_{x_{u}} \mu_{x} L_{x}}{\left(P_{x_{l}}^{2}-P_{x_{u}}^{2}\right) A}
$$

where:

(Eq. 1)

$k=$ coefficient of permeability $\left(\mathrm{m}^{2}\right)$

$\mu_{x}=$ dynamic viscosity based on the air temperature $\left(\mathrm{N} \cdot \mathrm{s} / \mathrm{m}^{2}\right)$

$Q_{e}=$ exit volumetric flowrate of $\operatorname{air}\left(\mathrm{m}^{3} / \mathrm{s}\right)$

$\mathrm{L}_{\mathrm{x}}=$ distance between pressure ports upper and lower (m)

$A=$ cross sectional area of column $\left(\mathrm{m}^{2}\right)$

$P_{x_{u}}=$ air pressure at upper pressure port $\left(\mathrm{N} / \mathrm{m}^{2}\right)$

$P_{\mathbf{x}_{1}}=$ air pressure at lower pressure port $\left(\mathrm{N} / \mathrm{m}^{2}\right)$

\subsubsection{Sample Calculation}

Using Equation 1, air permeability was calculated for each location in the column. The following sample calculation shows each step of the process for Column Test 3, permeability pretest measurement (between ports 1 and 2). See DTN \# MO0106EBSCT3AP.004 and/or SN-M\&O-SCI-016-V2 for raw data that are input to each of the permeability calculations (Lowry 2001b). Permeability was calculated in an Excel spreadsheet using this method.

Measured Values:

Air Flow $\quad=4.97 \mathrm{slpm}$

Differential Pressure (lower to atmospheric) $=0.086$ in. WC

Differential Pressure (lower to upper) $\quad=0.005$ in. WC

RTD Temperatures $\quad=(27.9,26.5,26.2,25.8,26.4,26.5,26.5,26.5,26.8$, $26.8,26.8,27.2,27.3,26.9){ }^{\circ} \mathrm{C}$

Distance between Pressure Ports $1 \& 2=0.0927 \mathrm{~m}$

Diameter of Column $\quad=0.1469 \mathrm{~m}$

Intermediate Calculations: (Since an Excel spreadsheet was used to perform these calculations all decimal points were carried out in the intermediate calculations.)

1. Calculate Atmospheric Pressure

Using Linear interpolation with elevation (USGS 1969) and pressure values from (Weast 1984):

Elevation of Las Vegas, NV $\quad=594 \mathrm{~m}$

Pressure@ @ 500m above sea level=95461 N/m²

Pressure@1000m above sea level=89876 N/m²

The resulting linear relationship between elevation and pressure is:

$\mathrm{Y}\left(\mathrm{N} / \mathrm{m}^{2}\right)=\left(-11.17^{*}\right.$ Elevation $\left.\mathrm{m}\right)+101046$

$\therefore$ Atmospheric Pressure @ $594 \mathrm{~m}=(-11.17$ * $594 \mathrm{~m})+101046$

$=94411 \mathrm{~N} / \mathrm{m}^{2}$ 
2. Calculate Air Temperature

$=(27.9+26.5+26.2+25.8+26.4+26.5+26.5+26.5+26.8+26.8+26.8+27.2+27.3+$ 26.9)/14 (Note: The $15^{\text {th }}$ RTD failed prior to air permeability measurements.)

$=26.72143^{\circ} \mathrm{C}$

$=299.87 \mathrm{~K}$

3. Calculate Dynamic Viscosity $(\mu)$ in Ns/m2

Using Linear interpolation from values taken from (Weast 1984):

Dynamic Viscosity @ $18^{\circ} \mathrm{C}=182.7$ micropoise

Dynamic Viscosity @ $40^{\circ} \mathrm{C}=190.4$ micropoise

The resulting linear relationship is relating dynamic viscosity (micropoise) to temperature $(\mathrm{K})$ is:

$\mathrm{Y}($ micropoise $)=(0.35 *$ Temperature $\mathrm{K})+80.798$

$\therefore$ Dynamic Viscosity @ $299.87=[(0.35 * 299.87 \mathrm{~K})+80.798] *(0.000001$ poise $/ 1$ micropoise $) *\left(0.1 \mathrm{Ns} / \mathrm{m}^{2} / 1\right.$ poise $)$

$=1.8575 \mathrm{e}-5 \mathrm{Ns} / \mathrm{m}^{2}$

4. Calculate Lower Pressure $\left(\mathrm{P}_{1}\right)$ in $\mathrm{N} / \mathrm{m}^{2}$

$=\left[\left(\right.\right.$ lower to atm pressure (in. WC) $*\left(248.84 \mathrm{~N} / \mathrm{m}^{2} / 1\right.$ in. WC) $]+($ Atmospheric Pressure $)$

$=\left[(0.086\right.$ in. WC $) *\left(248.84 \mathrm{~N} / \mathrm{m}^{2} / 1\right.$ in. WC $\left.)\right]+\left(94411 \mathrm{~N} / \mathrm{m}^{2}\right)$

$=\left(21.40024 \mathrm{~N} / \mathrm{m}^{2}\right)+\left(94411 \mathrm{~N} / \mathrm{m}^{2}\right)$

$=94432.40024 \mathrm{~N} / \mathrm{m}^{2}$

5. Calculate Upper Pressure $\left(P_{u}\right)$ in $N / m^{2}$

$=\left(\right.$ Upper Pressure $\left.\left(\mathrm{N} / \mathrm{m}^{2}\right)\right)-\left[\left(\right.\right.$ upper to atm pressure (in. WC) $*\left(248.84 \mathrm{~N} / \mathrm{m}^{2} / 1\right.$ in. WC) $]$

$=\left(94432.40024 \mathrm{~N} / \mathrm{m}^{2}\right)-\left[(0.005 \text { in. WC })^{*}\left(248.84 \mathrm{~N} / \mathrm{m}^{2} / 1\right.\right.$ in. WC $\left.)\right]$

$=\left(94432.40024 \mathrm{~N} / \mathrm{m}^{2}\right)-\left(1.2442 \mathrm{~N} / \mathrm{m}^{2}\right)$

$=94431.15604 \mathrm{~N} / \mathrm{m}^{2}$

6. Calculate Average Pressure $\left(P_{\text {avg }}\right)$ in $N / \mathrm{m}^{2}$

$=\left[\left(\right.\right.$ Upper Presssure $\left.\left(\mathrm{N} / \mathrm{m}^{2}\right)\right)+\left(\right.$ Lower Pressure $\left.\left.\left(\mathrm{N} / \mathrm{m}^{2}\right)\right)\right] / 2$

$=\left[\left(94432.40024 \mathrm{~N} / \mathrm{m}^{2}\right)+\left(94431.15604 \mathrm{~N} / \mathrm{m}^{2}\right)\right] / 2$

$=94431.77814 \mathrm{~N} / \mathrm{m}^{2}$

7. Convert Flow $\left(\mathrm{Q}_{\mathrm{e}}\right)$ from slpm to $\mathrm{m}^{3} / \mathrm{s}$ :

$=(4.97 \mathrm{std}$ liters $/ \mathrm{min}) *\left(\mathrm{P}_{\text {std }} / \mathrm{P}_{\mathrm{avg}}\right)$

$=(4.97 \mathrm{std}$ liters $/ \mathrm{min}) *\left(101000 \mathrm{~N} / \mathrm{m}^{2} / 94431.77814 \mathrm{~N} / \mathrm{m}^{2}\right)$

$=5.3156894 \mathrm{lpm}$

$=(5.3156894$ liters $/ \mathrm{min}) * 1 \mathrm{~m}^{3} / 1000$ liters $) *(1 \mathrm{~min} / 60 \mathrm{secs})$

$=8.85948 \mathrm{e}-5 \mathrm{~m}^{3} / \mathrm{s}$

8. Calculate Area of column (A) in meters $=\pi^{*}(\text { Diameter } / 2)^{2}$

$=(3.14) *(0.1469 \mathrm{~m} / 2)^{2}$

$=0.01695 \mathrm{~m}^{2}$ 
Permeability Calculation:

1. Calculate Air Permeability $\left(\mathrm{m}^{2}\right)$

$=\frac{2 Q_{e} P_{x_{u}} \mu_{x} L_{x}}{\left(P_{x_{i}}^{2}-P_{x_{u}}^{2}\right) A}$

$=\left[\begin{array}{lllll}(2)^{*}(8.85948 \mathrm{e}-5 & \left.\mathrm{m}^{3} / \mathrm{s}\right)^{*}(94431.15604 & \left.\mathrm{N} / \mathrm{m}^{2}\right)^{*}(1.8575 \mathrm{e}-5 & \left.\mathrm{Ns} / \mathrm{m}^{2}\right)^{*}(0.0927 & \mathrm{m})\end{array}\right] \quad /$

$\left[\left(\left(94432.40024 \mathrm{~N} / \mathrm{m}^{2}\right)^{2}-\left(94431.15604 \mathrm{~N} / \mathrm{m}^{2}\right)^{2}\right) *(0.01695)\right]$

$=7.233 \mathrm{e}-9 \mathrm{~m}^{2}$

Mean Permeability Calculation:

The mean permeability measurement for each test was determined by adding each of the nine calculated permeabilities and dividing the sum by 9 .

\subsubsection{Air Permeability Results}

The air permeability distribution resulting from measurement on Column Test 3 is shown in Figure 14. Using the stated accuracies of the air flowmeter and differential pressure transducer used in these measurements, the uncertainty in the permeability measurements ranges from $11 \%$ to $25 \%$, with greater uncertainty at the higher permeability values. The mean of the pre-test measured permeabilities is $6.573 \mathrm{E}-9 \mathrm{~m}^{2}$ whereas the mean of the post-test permeabilities is 5.523E-9 $\mathrm{m}^{2}$ (Lowry 2001b). During the post-test permeability measurements, a reading between port i (see Figure 3) and port 1 was attempted, but air could not be forced into port $i$ sufficiently to get a reading (Lowry $2001 \mathrm{~b}$ ). Mineral precipitates surrounding the ball bearings caused the air permeability in that section to be very low. In the top and bottom lifts, measurable decreases in permeability were noted, while the balance of the column showed very little change. For comparison, the intrinsic permeability of the crushed tuff used in the pretest prediction is $6.152 \times 10^{-10} \mathrm{~m}^{2}$ (DTN\# SN9908T0872799.004), very close to the mean values measured in these tests. Results for both tests are summarized in Tables 5 and 6.

\subsection{GEOCHEMICAL RESULTS}

\subsubsection{Column Fluid Cation and Anion Analyses}

Column Test 3 cation sampling times and results are listed in Table 7, while anion results are listed in Table 8. A preservative of 14 normal trace metal grade nitric acid was added to the cation samples while the anion and alkalinity samples did not receive a preservative. Final cation results were determined by multiplying the raw data by a dilution factor, which is based on the volume of nitric acid added to the sample (Lowry 2001b). Column Test $3 \mathrm{pH}$ values are listed in Tables 9 (DTN\# MO0106EBSCT3PH.005) and 10 (DTN\# MO0106EBSCT3PH.006) with solution temperatures at the time of measurement. Tables 9 and 10 also list column temperatures at the approximate time samples were removed from the column. These column temperature data are referenced from the logged process data (DTN\# MO0107EBSTHCT3.007). Table 10 list $\mathrm{pH}$ values that were measured outside of the calibration curve and are considered 
non- $Q$ data. These data are reported as additional information only. Cation, anion, and total alkalinity data are plotted with $\mathrm{pH}$ data in Figures $15-18$.

\subsubsection{Petrographic Examination of Thin Sections}

The data and petrographic images reported in this section are taken from Peterman 2001. General observations of the thin section mounts showed reaction rims on the outermost parts of the grains and amorphous silica deposits formed on grain surfaces. Reaction rims are typically 0.2 to $0.3 \mathrm{~mm}$ thick. In some grains, the rims exhibit a bleached appearance and in others, they appear to be oxidized. Figure 19 shows an example of the reaction rims observed along grain in a sample removed from Lift 1, Sample Number 00573024 (see Table 3). The amorphous silica is colorless with moderate negative relief and occurs as a thin coating on many of the grains and as fiber-like outgrowths up to $0.3 \mathrm{~mm}$ long and $0.03 \mathrm{~mm}$ wide. The outgrowths are commonly oriented orthogonal to the grain surfaces.

Samples collected from Lift 1, which is located at the column bottom, showed the most evidence of secondary-mineral deposits. The samples provided for analysis from Lift 1 consisted of cemented tuff grains with a few loose grains. Figure 20 shows tuff grains from Lift 1 with filamentous silica growths. Samples from the upper portion of Lift 1 showed discontinuous silica coating on some of the grains, while samples from Lifts 2, 5, 8, and 10 showed little evidence of secondary silica (see Section 5.3.3.2 for more information about silica deposition). Cementing material collected from around the ball bearings, located in Lift 1 at the column bottom, appeared to be fragments of tuff and small fragments of amorphous silica (see Table 3).

\subsubsection{Mineralogical Analysis Results}

QXRD results are listed in Table 11. The table is divided into three sections: pre-test crushed tuff (unwashed), post-test tuff from Lift 10, and post-test cement material. Based on the QXRD results the cementing material from Lift 1 is mostly amorphous silica (92 and 96\%) with small portions of opal-CT (5 and 2\%) and physical inclusions of feldspar and quartz detritus ( 3 and $2 \%$ ) (see Table 11). Secondary-mineral deposition in Lift 1 and evidence pertaining to mineral dissolution in Lift 10 will be discussed in Section 5.3.3.

\subsubsection{Column Solids Loading and Unloading Mass Results}

Crushed-tuff material organized in individual lifts were weighed prior to column loading and following the test. Different balances were used for column loading and unloading. The balance used to weigh the lifts before the test is a Mettler PM16-k with a capacity of $16,000 \mathrm{~g}$, a readability of $0.1 \mathrm{~g}$, and uncertainty of $+/-0.5 \mathrm{~g}$ (Lowry 2001c, p. 41). The balance used to weigh the lifts following the test is a Mettler PM4000 with $4000 \mathrm{~g}$ capacity, a readability of 0.01 $\mathrm{g}$, and an uncertainty of $+/-0.06 \mathrm{~g}$ (Lowry $2001 \mathrm{c}, \mathrm{p} .41$ ). Lift weights measured pre- and posttest with percent differences are listed in Table 12 . Percent differences were calculated using the following:

$$
\text { (Post-Test Weight }- \text { Pre-Test Weight)/[(Post-Test Weight + Pre-Test Weight)/2] }
$$


Figure 21 shows a photograph of a cemented tuff sample removed from Lift 1. Additional images showing cemented tuff grains and the cemented layer at the column bottom (Lift 1) are provided in Attachment III.

\subsubsection{Column $\mathrm{CO}_{2}$ Analysis Results}

The measured $\mathrm{CO}_{2}$ compositions of the samples are listed in Table 13. Analysis of ambient $\mathrm{CO}_{2}$ samples showed the test bay air to be in the range of 0.040 to $0.076 \% \mathrm{CO}_{2}$ (400 to $760 \mathrm{ppm}$ ). The steam vent line samples tended to be higher than the ambient air (sometimes as much as 3 times higher $\mathrm{CO}_{2}$ ), although two sampling events did not yield an increase in $\mathrm{CO}_{2}$ in the vent sample. In virtually all cases the column air showed a much higher concentration of $\mathrm{CO}_{2}$ than the room ambient air. Initial column gas samples showed relatively high concentrations $(8.21 \%$ on $9 / 25 / 00,14.73 \%$ on $12 / 6 / 00$, and $8.89 \%$ on $12 / 18 / 00$ ), while later sampling under less steady column operation showed reduced values. For the later test period (12/19/00 through 1/10/01), the column operation was less steady due to an unintentional shutdown over the holiday period, and intentional variations in the inlet air injection rate and cooling cap temperatures.

To determine the partial pressure of the $\mathrm{CO}_{2}$ in the column, the partial pressure of the air in the column must be known. This could be determined by evaluating the thermodynamic properties of the mixture given the measured temperature and pressure, but the temperature measurements of the column would have to be several orders of magnitude more accurate than the sensing system used. An alternate method uses the measured amount of water made up by the column's constant head water supply during the gas sampling event (which is assumed to be equal to the water vapor lost in the sampling process), and an estimate of the air sample volume collected in the sample bag. These data are listed in Table 13. Qualified data is used for the water make-up mass determination. The data and plots used to determine this are included in Attachment III. Visual estimates (non-qualified) of the sample bag air sample volume are listed in Table 13.

To determine the volume fraction of the air in the total column gas and vapor mixture, the air sample volume is adjusted for its volume under the column temperature conditions. This is determined by correcting the room temperature volume for temperature to yield an in-column volume:

Estimated sample volume at column temperature $=$

Estimated sample volume $_{\text {Room Temp }} *$ (temperature Column $_{\text {temperature }}$ Room $)$

Temperature units are in the absolute scale. An example calculation is for the $12 / 18 / 00$ column sample in Table 13 (estimated sample volume is recorded in SN-M\&O-SC1-016-V2, Lowry 2001b, p. 167, and temperature data is from DTN\# MO0107EBSTHCT3.007):

Estimated sample volume Room Temp $=500 \mathrm{cc}$ (non-Q)

Temperature ${ }_{\text {Column }}=93.9463^{\circ} \mathrm{C}$ (sensor CT1-RTD09)

Temperature $_{\text {Room }}=23.7921^{\circ} \mathrm{C}$ (sensor CT1-TEMP)

Estimated sample volume at column temperature $=$ 
$500 \mathrm{cc} *((93.9463+273.15) \mathrm{K} /(23.7921+273.15) \mathrm{K})$

$=618.1 \mathrm{cc}$

This and all subsequent calculations are reduced to four significant figures.

The volume of water vapor removed during the sample process is the product of the mass of the water removed and the specific volume of the water vapor under column conditions. The specific volume of water vapor under column conditions is determined by interpolating steam tables (Weast 1977, p. E-21) for the temperature measured near the sampling port. An example calculation for the $12 / 18 / 00$ column sample in Table 13 is:

Column temperature $(\mathrm{CT} 1-\mathrm{RTD} 09)=93.9463^{\circ} \mathrm{C}=201.1^{\circ} \mathrm{F}$

Specific volumes in (Weast 1977 p. E-21) are

(a) $201{ }^{\circ} \mathrm{F}$, steam specific volume $=32.996 \mathrm{ft}^{3} / \mathrm{lbs}$

$@ 202^{\circ} \mathrm{F}$, steam specific volume $=32.367 \mathrm{ft}^{3} / \mathrm{lbs}$

Linear interpolation provides the value of water vapor specific volume at $\mathrm{T}=201.1^{\circ} \mathrm{F}$ :

Water vapor specific volume $(\mathrm{v})$ at column temperature $=\mathrm{v}_{\mathrm{T} 1}-\left(\mathrm{v}_{\mathrm{T} 1}-\mathrm{v}_{\mathrm{T} 2}\right) *(\mathrm{~T}-\mathrm{T} 1)$

where:

$$
\begin{aligned}
& \mathrm{T} 1=201{ }^{\circ} \mathrm{F} \text { and } \mathrm{v}_{\mathrm{T} 1}=32.996 \mathrm{ft}^{3} / \mathrm{bm} \\
& \mathrm{T} 2=202{ }^{\circ} \mathrm{F} \text { and } \mathrm{v}_{\mathrm{T} 1}=32.367 \mathrm{ft}^{3} / \mathrm{bm}
\end{aligned}
$$

Water vapor specific volume at column temperature $=$

$32.996-(32.996-32.367) *(201.1-201.0)$

$$
=32.93 \mathrm{ft}^{3} / \mathrm{lbm}
$$

Conversion of units yields:

$$
\left(32.931 \mathrm{ft}^{3} / \mathrm{lbm}\right) /\left(0.016018(\mathrm{cc} / \mathrm{g}) /\left(\mathrm{ft}^{3} / \mathrm{lbm}\right)\right)=2056 \mathrm{cc} / \mathrm{g}
$$

To determine the volume of steam in the extracted water at column conditions, multiply the steam specific volume by the mass of water as indicated by water loss during sampling:

Steam volume @ column conditions=1451.5 g*2056 g/cc

$$
=2.984 \mathrm{e}+6 \mathrm{cc}
$$

The fraction of the mixture occupied by the air is then

Sample volume@ column conditions/(steam volume@ column conditions + sample volume @ column conditions)

$=618.1 \mathrm{cc} /(2.984 \mathrm{e}+6 \mathrm{cc})$

$=2.071 \mathrm{e}-4$

The air partial pressure is the product of the air fraction and the total pressure: 
Air partial pressure $=2.071 \mathrm{e}-4 * 964.095 \mathrm{mbars} *(100 \mathrm{Pascals} / \mathrm{mbar})=19.97 \mathrm{~Pa}$

The $\mathrm{CO}_{2}$ partial pressure in the column is then the product of the measured concentration of $\mathrm{CO}_{2}$ in the sample and the air partial pressure:

$\mathrm{CO}_{2}$ partial pressure $=\mathrm{CO}_{2}$ concentration $*$ air partial pressure

$$
=(8.89 \% / 100) * 19.97 \mathrm{~Pa}
$$

$=1.775 \mathrm{~Pa}$

Note that the values calculated in Table 13 for $\mathrm{CO}_{2}$ partial pressure range from 0.04573 to 5.085 $\mathrm{Pa}$. 


\section{DISCUSSION OF TEST RESULTS}

\subsection{PROCESS DATA INTERPRETATION}

\subsubsection{Overview}

Process data were recorded during the column experiments in order to establish and track operational parameters. The column heater was energized on September 18, 2000. After the heater was energized, column temperatures became stable in about six hours (see Figures 12 and 13). There were three major events that affected heater power over the course of the test (Table 1). On September 29, 2000, the heater element failed and was replaced on October 5, 2000. On November 17, 2000, the heater power was interrupted for a planned facility wide power outage until November 20,2000. As a result of this power outage, the chiller was damaged and was not fully repaired until November 29,2000 . The final event occurred as a result of the water inlet valve being inadvertently left closed after a sampling event on December 19, 2000. As a result of water not entering the column to replace the loss through the steam vent, the column bottom temperature heated above the safety setting and caused the column heat to cycle on and off over a period of several days. The closed valve was observed on January 4, 2001 and reopened at that time. Potential effects to the column test may have been a shortened test duration caused by an increase in mineral precipitation during this drying period. The increase in mineral precipitation would have increased the thickness of the mineral deposits at the column bottom, and thereby increase the amount of heat required to boil the water in the column. Minor interruptions to column process operations included sampling events where the insulation was removed from the column while fluid and air were drawn from the column, and short periods (hours) of heater power interruption. In order to verify the column operational conditions, heat and water balance calculations were performed using the measured operational parameters. Sections 5.1.2 and 5.1.3 cover the column heat balance and water balance analyses.

\subsubsection{Heat Loss Calculations and Column Heat Balance}

Column Test 3 heat loss analyses were performed during periods of stable column operation. The heat loss analysis was performed by calculating the heat removal rates from the cooling cap and then calculating the percent removal rates based on the column heater input. Heat removal from the cooling cap is calculated by:

$$
\dot{Q}=\dot{m} \cdot C_{p} \cdot \Delta T
$$

where

$$
\begin{aligned}
& \dot{Q}=\text { heat removalrate }(\mathrm{W}) \\
& \dot{m}=\text { massflow rate }(\mathrm{kg} / \mathrm{s}) \\
& C_{p}=\text { specificheat of water }(\mathrm{J} /(\mathrm{kg} \cdot \mathrm{K})) \\
& \Delta T=\text { temperature difference of inlet and outlet cooling water }(\mathrm{K})
\end{aligned}
$$


Figure 22 shows column power input, heat removal through the cooling cap, and the difference between heat input and output. The difference between the heat input and output is the heat lost to the surroundings through the insulation on the column bottom and sides and via water vapor vented through the steam vent at the top of the column. Heat removal rates are only available starting on November 16, 2000 due to a DAS interface error with the cooling cap flow meter (CT1-FLO1). Heat removal percentages for the period starting on November 16, 2000 through the end of the test are plotted in Figure 23. The average heat removal rate from November 16, 2000 through the test duration is 69.13\% (DTN\# MO0109EBSCT3HD.008). The highest rate was $77.92 \%$, occurring in November shortly after the cooling cap flow meter was brought online (DTN\# MO0109EBSCT3HD.008).

\subsubsection{Column Water Balance and Reflux}

Mass water balance calculations were performed for the period of December 7, 2000 through December 18, 2000 (which was a period of stable operation) do to an inherent complexity in performing a mass water balance over the duration of the test (i.e. complexities caused by interruptions in power and maintenance events). The mass balance was performed by converting the scale mass measurements over time to flows for both scales used to measure water mass input and water mass output. Water flows into and out of the system were calculated by summing the flows during this period and subtracting large volume changes, which are attributed to events not related to water leaving the column through the steam vent. These include sampling events, and evaporation from the supply and collection containers. Although the supply and collection containers were covered, they were open to the atmosphere through holes used to convey tubing into the containers. The cross sectional area exposed to the atmosphere in both containers was the gap between the tubing and the hole edge. The evaporation rate from the supply tank was determined during the period when the water supply valve was closed $(12 / 19 / 00$ to $1 / 4 / 01$ ), and no water was flowing out of the supply tank. Since environmental conditions (e.g., temperature) in the supply and collection tanks were nearly identical, the supply tank evaporation rate was applied to the collection tank. The average evaporation rate during this period was $0.0015 \mathrm{~kg} / \mathrm{hr}$ based on a linear trend line (Lowry 2001c, p. 71). Other events, referred to as Large Scale Changes, represent artificial spikes in the scale data caused by unintentional agitation of the scales during sampling and maintenance events. The following formulae represent the mass water balance summations:

Flow In (Column System) $=$

$$
\Sigma(\Delta \text { Mass }+\Delta \text { Evaporation }- \text { Sampling Events - Large-Scale Changes) }
$$

Flow Out (Column System) =

$\Sigma$ ( $\Delta$ Mass $+\Delta$ Evaporation - Large-Scale Changes)

The total calculated water input was $0.93 \mathrm{~kg}$ and the total calculated water removal was $0.694 \mathrm{~kg}$ for a difference of $0.24 \mathrm{~kg}$ during the period of December 7, 2000 through December 18, 2000 (Lowry 2001 c, pp. 72-80). Based on the removal of $0.694 \mathrm{~kg}$, the loss rate out of the column is $0.06 \mathrm{~kg} /$ day $(0.0025 \mathrm{~kg} / \mathrm{hr})$. Figure 24 shows the column water input and output mass flow rates plotted with the estimated mass reflux rate during this period. 
The mass reflux rate due to condensation of vapor on the cooling cap, and infiltration of that water down through the tuff, can be estimated with the following equation:

Mass Reflux Rate $=($ heat removal rate $(\mathrm{J} / \mathrm{s})) /($ Heat of Vaporization $)$

where:

Heat of Vaporization $=2.449 \times 10^{6} \mathrm{~J} / \mathrm{kg}$ (Lowry 2001c, p. 94)

The average volumetric flow rate of water condensed by the cooling cap during this 11.77-day period was 9.718-lpd, and the estimated total mass reflux rate was $114.35 \mathrm{~kg}$ (Lowry 2001c, p. 94-102). The percentage of water lost through the steam vent is $0.607 \%$ [(0.694/114.35)*100] of the daily reflux rate, which is supporting evidence that the column system is virtually a closed system (Lowry 2001c, p. 81).

\subsection{SOLIDS MASS MOVEMENT}

The air permeability at the bottom of the column ( 0.09715 meters from the heated surface) decreased from $7.234 \mathrm{E}-09 \mathrm{~m}^{2}$ at the beginning of the test to $4.005 \mathrm{E}-09 \mathrm{~m}^{2}$ at the end of the test (see Figure 14, Tables 5 and 6), and the air permeability between ports $i$ and 1 could not be measured because air could not be forced into the column through port i during measurement. The decreases in permeability in Lift 1 can be attributed to secondary mineral precipitated on the surfaces of tuff grains. Permeability changes in the middle lifts are smaller or almost nondetectable. It was originally thought that dissolution of minerals in the upper lifts would cause the permeability in those lifts to increase. Although there has been a substantial movement of solids to the column bottom, the removal of this material has not been enough to increase the air permeability in the upper lifts.

Lift 1 had a mass increase of $0.10 \mathrm{~kg}(6.1 \%$ increase), while Lift 10 lost $0.0296 \mathrm{~kg}(1.8 \%$ decrease) (see Table 12). Lifts 9 through 2 showed mass losses that were lower than the loss in Lift 10, but still measured well above the highest balance uncertainty of $+/-0.0005 \mathrm{~kg}$. A plot of the mass changes for the 10 column lifts is provided in Figure 25. By nature of the unloading procedure, a small amount of un-quantifiable materials in the form of dust and fines were lost in the vacuum system, spilled, and suspended in the ambient air. Based on the total initial and final weights, a total mass of $0.0271 \mathrm{~kg}$ of material was lost from the test (Table 12). The curve in Figure 25 shows that the loss in material is uniform through the center region of the column (Lifts 2 through 8). Based on this information, it appears that the loss in material during the column unloading process would have been evenly distributed throughout the column, with the exception of Lift 1, which was not removed with the vacuum system. Lift 1 was removed last and after the column base (or lower cylinder) was separated from the upper column (see Figure 2). The loose material in Lift 1 was removed by hand then the column base was weighed. The column base post-test weight was compared to the pre-test weight to accurately determine the mass of the cement and accumulated material in Lift 1. During unloading, visual inspection of Lift 1 revealed a high degree of secondary mineral deposition. The ball bearing layer (located in Lift 1) was completely filled with mineral deposits, and the tuff was cemented below the saturation level (Figure 21). 


\subsection{GEOCHEMISTRY}

\subsubsection{Overview}

The geochemical environment inside the column is directly affected by the hydrothermal system discussed in Section 3.7. This process is analogous to a conveyer belt that moves rock mass from the upper portions of the column down to the saturated zone. Pure water is delivered to the top of the column as the steam is condensed by the cooling cap. The liquid water dissolves minerals on its way back down to the boiling zone and deposits them as precipitates in the saturated zone. The rate of mass transport should be proportional to the rate at which steam is condensed into liquid water.

The total dissolved solids concentration in the saturated zone began to rise as more dissolved species were delivered to the bottom of the column by this process. At some point, the solution composition became supersaturated with respect to a given mineral phase. This resulted in precipitation of that mineral as secondary mineralization. A photograph of the column bottom with a portion of the cemented material removed is provided in Figure 26. A discussion of the column fluid geochemistry and the minerals precipitated at the column bottom and Lift 1 test materials is provided in the following sections.

\subsubsection{THC Column Fluids}

\subsubsection{Column Test 3 Fluids}

As a basis for determining chemical input into the column, the fluid from the column water supply container was analyzed for cations, anions, and $\mathrm{pH}$. Cation and anion levels in the column supply water were either non-detectable or extremely low (see Tables 7 and 8). Column water supply $\mathrm{pH}$ values measured on September 18 and 19,2000, prior to the start of Column Test 3 were 7.99 and 7.36, respectively (see Table 9) (DTN\# MO0106EBSCT3PH.005).

Solution $\mathrm{pH}$ displayed two interesting trends over the life of Column Test 3. It must be pointed out that the $\mathrm{pH}$ measurements in this report were measured at room temperature and do not represent the same $\mathrm{pH}$ values occurring in the column at elevated temperatures. For this reason, the discussion of $\mathrm{pH}$ will be based upon trends observed from the measurements taken at room temperature. One particular characteristic of column solution $\mathrm{pH}$ is the drop that occurs during the first four hours after the column heater is energized. This drop is well pronounced during column startup and occurs to lesser degrees each time the column heater is shutdown and restarted during interruptions in the column power supply (Figure 27). Figure 27 shows a plot of column solution $\mathrm{pH}$ annotated with significant process events. This characteristic drop was observed by Rimstidt and Williamson (1991) and was attributed to the hydrolysis of $\mathrm{Fe}^{2+}$ and $\mathrm{Mn}^{2+}$ leached from the tuff. The hydrolysis of $\mathrm{Fe}^{2+}$ and $\mathrm{Mn}^{2+}$ may be a factor in the initial $\mathrm{pH}$ drop observed in Column Test 3, however, in Column Test 3 iron and manganese concentrations were non-detectable (see Table 7), and it is beyond the scope of this report to determine specific interactions. Another characteristic of the column solution $\mathrm{pH}$ is that during long periods of stable column operation the solution $\mathrm{pH}$ rises above the highest calibration point $(10.01)$ and stabilizes around 10.3 (Table 10). The $\mathrm{pH}$ procedure and buffers used were developed for 
groundwater analysis, hence the limited upper range. In the prior two column tests this range had not been exceeded. Because of the extended duration of Column Test 3 , the $\mathrm{pH}$ values rose beyond the calibration limit. The solution $\mathrm{pH}$ values measured above the calibration curve are reported as non-Q data. These results were reported to illustrate that solution $\mathrm{pH}$ values increased and stabilized above the 10.01 point. It is possible that the carbonate system is a dominant factor in controlling $\mathrm{pH}$ levels in the column fluid. This conclusion is based on the stabilization or buffering of the column solution $\mathrm{pH}$ at around 10.3 (based on measurements outside the calibration curve, i.e., above 10.01), which is the $\mathrm{pH}$ level at which the bicarbonate and carbonate ion activities (or concentrations) are equal (i.e., the isoactivity point) at $25{ }^{\circ} \mathrm{C}$. Although the carbonate system may be a dominant factor in controlling column $\mathrm{pH}$ levels, other systems such as silicic acid dissociation should not be ruled out at the higher temperatures and elevated silica concentrations found in the column environment.

Like the $\mathrm{pH}$ measurements, cation and anion measurements were performed at a different temperature and in a different $\mathrm{pH}$ than the column environment. For this reason cation and anion measurements may not directly represent the chemical species found in the column test environment. For example, aluminum $\left(\mathrm{Al}^{+3}\right)$, which is measured as a cation, would probably exist as the aluminate anion at the higher $\mathrm{pH}$ values in the column. The discussions pertaining to cation and anion concentrations will be limited to the trends observed in the measured results.

Each of the cations followed a similar pattern over the experiment duration (see Figures 17 and 18). Sodium $\left(\mathrm{Na}^{+}\right)$and Silica show the highest concentration peaks at 235.83 and $723.78 \mathrm{mg} / \mathrm{L}$, during the first week in November 2000 (see Table 7 and Figure 17). Cation concentrations show a moderate relative increase after the test startup on September 19, 2000 and the restart on October 5, 2000, following the heater element malfunction. The period between October 5 and November 17, 2000, a period of continuous column operation, reveals interesting activity with respect to cation concentrations. All measured cations increase sharply during this period until the first week in November when there is a dramatic drop in all cation concentrations. This drop in cation concentrations may be the result of a nucleation-precipitation event. In such an event, minerals other than amorphous silica would be formed. Aluminum $\left(\mathrm{Al}^{3+}\right)$, calcium $\left(\mathrm{Ca}^{2+}\right)$, and potassium $\left(\mathrm{K}^{+}\right.$) peak on November 8, 2000 at $97.87,59.05$, and $32.74 \mathrm{mg} / \mathrm{L}$, respectively (see Table 7 and Figure 18). During this period of stable operation the pH measurements $\left(25^{\circ} \mathrm{C}\right)$ increase and stabilize above 10.00 , then remains around 10.00 or higher for the duration of the test.

Another interesting period with respect to cation trends is the period between November 21 , 2000 and January 8, 2001 (see Figure 17 and 18). Sodium and silica spike again on December 6, 2000 at 409.13 and $447.31 \mathrm{mg} / \mathrm{L}$, respectively, then decrease slowly through January 8 (see Table 7). Aluminum, calcium, and potassium concentrations remain low during this second uninterrupted period. Conversely, it appears that silica and sodium remain relatively available for reprecipitation in the saturated zone for further dissolution, which is evidenced in the second spike. Total alkalinity also shows a sharp increase during this period with a peak at $646 \mathrm{mg} / \mathrm{L}$ (as $\mathrm{CaCO}_{3}$ ), the highest total alkalinity concentration during the experiment (Figure 17). Potassium increased slightly on December 6, while aluminum and calcium concentrations remained flat. 
All anion concentration measurements show similar trends with the exception of phosphate $\left(\mathrm{PO}_{4}{ }^{3-}\right)$, which remains low $(<1.5 \mathrm{mg} / \mathrm{L})$ throughout the experiment (see Figures 15 and 16). Anion concentrations peak on September 25, 2000, six days after the column test is started. Sulfate $\left(\mathrm{SO}_{4}{ }^{2-}\right)$ and chloride $\left(\mathrm{Cl}^{-}\right)$ions show the largest increase over all other anions with concentrations at 293.8449 and $123.01 \mathrm{mg} / \mathrm{L}$, respectively (see Table 8). Following this peak, there is a drop in all anion concentrations until heater restart following the heater element malfunction, when anion levels spike again at lower concentrations. After this second spike, anion levels remain flat for the duration of the test with the exception of a small rise on December 6, 2000.

\subsubsection{Mineralogic Analysis}

\subsubsection{Mineralogy of the Starting Material}

As indicated by QXRD, the crushed-tuff starting material is completely crystalline and has a mineralogic composition typical of the Topopah Spring middle nonlithophysal zone. The major macroscopic inhomogeneities of this rock are the presence of natural fracture surfaces with a variety of mineral coatings and the local development of vapor-phase crystallization (a bleached appearance in the tuff). Quantitative XRD analyses of five aliquots are identical within the limits of analytical instrument error (Table 11). This documents the mineralogic homogeneity of bulk crushed tuff in quantities as small as $20 \mathrm{~g}$.

Minute quantities of millimeter-size calcite crystals were identified by ultraviolet fluorescence and physical properties. Such crystals are present as fracture and lithophysal-cavity fillings in the rock of the Topopah Spring middle nonlithophysal zone. The proportion of calcite to tuff is too small for the calcite to be detected by QXRD of the bulk crushed-tuff samples.

\subsubsection{Evidence of Secondary-Mineral Deposition}

The most abundant secondary-mineral deposition occurred in the ball-bearing layer (located in Lift 1) at the bottom of the column and within the crushed-tuff filling of Lift 1. The predominant constituent of the cement from the bottom of the column, as identified by $x$-ray diffraction, is an amorphous material. A material that is amorphous to $\mathrm{x}$-rays possesses no regular crystalline structure. The energy-dispersive $\mathrm{x}$-ray spectra for the cement contain strong Si peaks and little else. These data are interpreted to indicate that the cement is almost pure amorphous silica, also known as opal-A (Table 11). The $\mathrm{x}$-ray diffraction patterns also show the presence of a few weight percent of opal-CT, which is a poorly crystalline silica with short-range (up to a few hundred angstroms) cristobalite and tridymite ordering of the silicate tetrahedra. An SEM secondary-electron image of this silica cement is shown in Figure 28.

Small quantities of quartz and feldspar detected by XRD in the cement are fine rock particulates physically incorporated into the cement. These are visible as discrete inclusions under stereomicroscopic examination of the cement.

Thin deposits of transparent vitreous material were observed on the surfaces of a few crushed-tuff fragments from Lift 10 (Figure 29). The morphology and optical properties of the 
material are compatible with an identification of amorphous silica. These are not like natural opal-A deposits in the Topopah Spring Tuff, and they closely resemble some amorphous silica deposits observed in the thermal tests conducted in situ in the Topopah Spring middle nonlithophysal zone (Harrington 1998). The deposits fluoresce greenish in ultraviolet light, like the amorphous silica observed in the thermal tests. Energy-dispersive $\mathrm{x}$-ray spectra also suggest that these are silica deposits, possibly with a minor calcium-rich phase as well. The quantity of amorphous silica in the Lift 10 material, visually estimated to be much less than $1 \%$, is too small for detection by QXRD. Deposits like these were not observed during ultraviolet examination of the Lift 5 and Lift 8 material and are rare in the Lift 2 material, so this kind of silica deposit is not ubiquitous within the column.

\subsubsection{Evidence of Dissolution}

The search for evidence of dissolution concentrated on the material retrieved from Lift 10 because this is the lift with the largest measured weight loss, $1.8 \%$, resulting from the test (see Table 12). The conceptual model for the column test predicts that dissolution will occur at the top of the column where the water vapor condenses and flows downward through the crushed tuff. Mineralogic evidence of dissolution was sought by comparing quantitative XRD mineralogy of the pre-test crushed tuff and the material from Lift 10. Surface textures of Lift 10 post-test material were compared to pre-test tuff by SEM.

The bulk mineralogy of the Lift 10 post-test material is indistinguishable from the mineralogy of the starting material. This means that, within the sensitivity of the QXRD analytical technique, any change in the relative mineral proportions of the crushed tuff due to dissolution during the test was less than the intrinsic variability of the material and therefore undetectable. Scanningelectron microscopic examination found textural evidence of test-related dissolution only adjacent to amorphous silica deposits.

The possibility that dissolution occurred principally among fine particulates on the rockfragment surfaces was also considered. Representative images of crushed tuff washed in the same manner as the starting material were compared with images of post-test crushed tuff from Lift 10. The images were compared for maximum size of free particulates on the crushed-tuff surfaces and for estimated percent particulate coverage of the surfaces.

The largest particulates on the pre-test washed tuff are $20 \mu \mathrm{m}$ (maximum dimension), and the mean maximum size of particulates on the washed tuff is $10 \mu \mathrm{m}$. For post-test tuff from Lift 10, the largest particulates are $20 \mu \mathrm{m}$ and the mean maximum size is $9 \mu \mathrm{m}$. The range of surface coverage by particulates is 5 to $40 \%$ for pre-test washed tuff, with a mean coverage of $17 \%$. A larger range of surface coverage, 5 to $100 \%$, was observed for the post-test crushed tuff, but the mean coverage is $21 \%$. These data suggest that particulates were redistributed on the surfaces of the crushed-tuff fragments during the test but no net loss of particulates was detected after the test.

Local accumulations of particulates are present on the surfaces of Lift 10 crushed-tuff fragments. Whether these accumulations are inherited from the pre-test washing process or were produced by particulate transport and concentration during the test is unknown, although they seem more 
likely to be test products. There is no definite, general reduction in the abundance of semidetached particles in the Lift 10 post-test material relative to the pre-test material.

\subsubsection{Column $\mathrm{CO}_{2}$ Partial Pressure}

The $\mathrm{CO}_{2}$ sampling and analysis showed that the ambient air in the test area was of the expected $\mathrm{CO}_{2}$ concentration, the pore gas in the column showed relatively high concentrations, and the steam vent line composition was generally higher in $\mathrm{CO}_{2}$ than the ambient air, but much lower than that in the column gas. The qualitative assessment of air partial pressure in the column indicated that the air fraction was very low.

The $\mathrm{CO}_{2}$ in the column gas was as high as $14.73 \%$ in the early stages of the experiment, falling to levels near $1 \%$ in the later periods. When comparing column $\mathrm{CO}_{2}$ concentrations to the ambient values, which are expected to represent the injected air composition, the column gas samples are on the order of 1000 times higher in $\mathrm{CO}_{2}$ concentrations. The $\mathrm{CO}_{2}$ partial pressure, however, is the critical parameter in the geochemical analysis. The $\mathrm{CO}_{2}$ partial pressure is the product of the concentration in air and the air partial pressure. The estimated (non- $Q$ ) partial pressure of $\mathrm{CO}_{2}$ in the column gas (Table 13) ranged from 0.04573 to $5.085 \mathrm{~Pa}$.

Greater $\mathrm{CO}_{2}$ concentration in the column gas than in the column vent is likely the result of the higher solubility of $\mathrm{CO}_{2}$ at the elevated temperature in the column fill. This contrast in solubility under steady operating conditions would result in much higher $\mathrm{CO}_{2}$ in the column vapor mixture, since all of the column crushed tuff fill was over $90^{\circ} \mathrm{C}$, compared to the cooling cap region where water was condensed near $25^{\circ} \mathrm{C}$.

Some generation or addition of $\mathrm{CO}_{2}$ to the column over the test operation is evident from the consistently higher concentration of $\mathrm{CO}_{2}$ in the vent line air than the ambient air. The $\mathrm{CO}_{2}$ mass increase under ambient conditions, based on the steam vent and ambient $\mathrm{CO}_{2}$ values measured on 12/6/01 (see Table 13), is:

Increased $\mathrm{CO}_{2}=$ Nominal Air Injection Rate $*$ Change in $\mathrm{CO}_{2} * \mathrm{CO}_{2}$ Gas Density @ $25^{\circ} \mathrm{C}$ and Standard Pressure

where:

Density of $\mathrm{CO}_{2} @ 25^{\circ} \mathrm{C}$ and Standard Pressure (Gas Constant = $8.314(\mathrm{~L}-\mathrm{kPa}) /(\mathrm{mol}-\mathrm{K})$, Weast 1977, p. F-241)

$=(101.325 \mathrm{kPa} * 44.01 \mathrm{~g} / \mathrm{mol}) /(8.314(\mathrm{~L}-\mathrm{kPa}) /(\mathrm{mol}-\mathrm{K}) * 298.15 \mathrm{~K})$

$=1.799 \mathrm{~g} / \mathrm{L}$

$=0.001799 \mathrm{~g} / \mathrm{cc}$

Nominal air injection rate of $16 \mathrm{cc} / \mathrm{min}$ from Section 3.3.

Increased $\mathrm{CO}_{2}$, Corrected for Local Atmospheric Pressure

$=16 \mathrm{cc} / \mathrm{min} *(0.17 \%-0.051 \%) * 0.001799 \mathrm{~g} / \mathrm{cc} *(101.325 \mathrm{kPa} / 94.411 \mathrm{kPa})$

$=3.676 \mathrm{e}^{-5} \mathrm{~g} / \mathrm{min}$

The $\mathrm{CO}_{2}$ added in the make-up water is calculated as: 
$\mathrm{CO}_{2}$ added (water) $=$ Mass $_{\text {water }} *$ Equilibrium $\mathrm{CO}_{2}$ Concentration in Water

A conservative case is to use the $\mathrm{CO}_{2}$ concentration in water at room temperature, following Henry's Law of gas solubility:

$\mathrm{CO}_{2}$ Concentration in Water $\left(@ 25^{\circ} \mathrm{C}\right)$ in $\mathrm{g} \mathrm{CO}_{2} / \mathrm{kg}$ Water $=\left(\mathrm{CO}_{2}\right.$ in air $){ }^{*} \mathrm{k}_{\mathrm{H}}$ where:

$\mathrm{k}_{\mathrm{H}}=$ Henry's Law Constant ( $\mathrm{g} \mathrm{CO}_{2} / \mathrm{cc}$ Water)

$\mathrm{CO}_{2}$ Concentration in Water $\left(@ 25^{\circ} \mathrm{C}\right)$

$=0.04 \% * 0.00145 \mathrm{~g} \mathrm{CO}_{2} / \mathrm{cc}$ Water (Weast 1977, p. B-102)

$=5.8 \mathrm{e}^{-7} \mathrm{~g} \mathrm{CO}_{2} / \mathrm{cc}$ Water

The $\mathrm{CO}_{2}$ addition rate due to make-up water using $0.06 \mathrm{~kg}$ Water/day average make-up rate (see Section 5.1.3) is:

Mass of $\mathrm{CO}_{2}$ added (Water) $=0.06 \mathrm{~kg}$ Water/day * Mass of $\mathrm{CO}_{2}$ in Water

where:

Mass of $\mathrm{CO}_{2}$ in Water

$=\left(5.8 \mathrm{e}^{-7} \mathrm{~g} \mathrm{CO}_{2} / \mathrm{cc}\right.$ Water $) /(0.99707 \mathrm{~g} / \mathrm{cc}$ (Weast $1977, \mathrm{p} . \mathrm{F}-11) * \mathrm{~kg} / 1000 \mathrm{cc}$

$=5.817 \mathrm{e}^{-4} \mathrm{~g} \mathrm{CO}_{2} / \mathrm{kg} \mathrm{Water}$

Mass of $\mathrm{CO}_{2}$ added (Water)

$=0.06 \mathrm{~kg} \mathrm{Water} /$ day $* 5.817 \mathrm{e}^{-4} \mathrm{~g} \mathrm{CO} 2 / \mathrm{kg} \mathrm{Water} *($ day $/ 1440 \mathrm{~min})$

$=2.424 \mathrm{e}^{-8} \mathrm{~g} / \mathrm{min}$

Note that the potential mass rate addition of $\mathrm{CO}_{2}$ observed in the make-up water is much lower than the incremental increase in the $\mathrm{CO}_{2}$ observed in the steam vent. The other potential source of $\mathrm{CO}_{2}$ in the column is the internal generation of $\mathrm{CO}_{2}$ due to reactions in the column involving the fill material.

\subsection{RELEVANT THC STUDIES FROM CURRENT LITERATURE}

\subsubsection{Experimental Comparison with Rimstidt and Williamson}

It was noted earlier that the column experiment followed a similar design used by Rimstidt and Williamson (1991). The similarities and differences between the column experiment and the tests performed by Rimstidt and Williamson, called the Vertical Thermal Gradient Experiment (VTGE), will be outlined in this section. Because both tests were carried out using different test materials and under different process conditions, geochemical results will not be compared in detail, only experimental configuration. The most notable difference between the two experiments is the objectives. The column experiment was performed with the purpose of gathering geochemical data that will be used in the validation of THC model, while the VTGE was performed with the purpose of empirically understanding the geochemical processes that 
occur in a vapor dominated geothermal system. The two tests used similar configurations with a column used as the reaction vessel and a heat source applied at the base. In both tests, water is boiled at the column bottom and reflux occurs at the column cap and on the column sides as heat is lost through the outer insulating layer. In both tests, gases were vented to the atmosphere from the reaction vessels (or columns), and air was injected into the Column Tests, but air was not injected in the VTGE tests. In both tests, the water chemistry was analyzed for major cations, anions, and solution $\mathrm{pH}$. In addition, test material and secondary-mineral products were examined for signs of dissolution and mineral identification. Greater care was taken in Column Test 3 to constrain or measure the compositional variables in the test (such as dissolved inorganic carbon and $\mathrm{CO}_{2}$ in the gas) that can control the chemistry in the test.

Major operational parameters inherent in both the VTGE and the column test include energy input and heat removal, water input and steam output, test material classification, chemical composition of make-up water, geochemical analyses, solids mass movement, temperature distribution, data acquisition and collection frequency, and operation time. Table 14 outlines these major operational parameters and lists the methods used to examine the level of control/characterization in the VTGE and Column Test 3.

In a general comparison of geochemical results, secondary-mineral precipitation occurred in the VTGE and Column Test 3 with amorphous silica being the primary component in both tests. Etch pitting was observed on tuff grains in the VTGE, but no obvious evidence of pitting or dissolution was observed in on Column Test 3 test materials. Solution $\mathrm{pH}$ showed the same general trend in both tests with a characteristic dip in the first hours following heat application, then an increase. Differences in the $\mathrm{pH}$ trends were manifest in peak $\mathrm{pH}$ value. In a typical VTGE test, pH steadily increased throughout the test until a peak value was measured as the last data point (typically between 8 and 9), while in Column Test 3, pH increased to values above 10.00 , then stabilized for the duration of the test.

\subsubsection{Literature Review}

Experiments dealing with the dissolution of Yucca Mountain tuff and the precipitation of secondary mineral products have been performed at different levels of complexity. A summary of four experiments will be discussed in this section concentrating on the features relevant to the EBS THC column test. The most relevant is an experiment in which the dissolution and precipitation minerals in boiling water was studied (Kneafsey et al. 2001). Tuff dissolution was studied by equilibrating distilled-deionized water with $50,000 \mathrm{ppm} \mathrm{CO}_{2}$, then pumping the water through a column of Yucca Mountain Tuff until equilibrium was reached. The effluent water was then allowed to flow through a saw-cutfracture (in welded Yucca Mountain tuff) with a temperature gradient of $130^{\circ} \mathrm{C}$ at the bottom to $80^{\circ} \mathrm{C}$ at the top. During the tuff dissolution portion of the experiment, dissolution rates reached steady state in about 230 hours. During the precipitation portion, the fracture began to seal after approximately five days, and the solid precipitates were composed primarily of amorphous silica.

Oversby (1984) performed an experiment investigating the reaction of the Topopah Spring tuff with $\mathrm{J}-13$ well water at $90^{\circ} \mathrm{C}$ and $150^{\circ} \mathrm{C}$. The primary purpose of this experiment was to examine the changes in water chemistry that would result from increased temperature in Topopah Spring 
tuff. Topopah Spring tuff was crushed and then place in Teflon lined reaction vessels with J-13 well water, which were then placed in an oven at the specified test temperature, for approximately 50-70 days. The resulting solutions were analyzed for anions, cations, alkalinity, and $\mathrm{pH}$. Oversby (1984) found no significant increase in the anions Fluoride $\left(\mathrm{F}^{-}\right)$, Chloride $\left(\mathrm{Cl}^{-}\right)$, Nitrate $\left(\mathrm{NO}_{3}{ }^{-}\right)$, and Sulfate $\left(\mathrm{SO}_{4}{ }^{2-}\right)$. Solution silica concentrations increased to the level of cristobilite solubility. The reaction solutions became supersaturated with respect to aluminum $\left(\mathrm{Al}^{3+}\right)$ followed by a slow decrease concentration. Calcium $\left(\mathrm{Ca}^{2+}\right)$ and magnesium $\left(\mathrm{Mg}^{2+}\right)$ were found to precipitate rapidly.

Carroll et al. (1996) studied the interaction of cement (Fibercrete ${ }^{\mathrm{TM}}$ ), Topopah Spring tuff, a J-13 well water analog $\left(\mathrm{NaHCO}_{3}\right.$ solution), and diesel fuel at $200^{\circ} \mathrm{C}$. The emphasis of these tests was to experimentally investigate the stability of cementitious and tuffaceous materials in contact with a model ground water (J-13 well water) and diesel fuel (as an organic acid) at an elevated temperature $\left(200^{\circ} \mathrm{C}\right)$. Tests were performed with different combinations of the materials listed above. Two tests involving Topopah Spring tuff were performed, and only the results of these tests will be summarized with emphasis on the relevant features associated with tuff mineralogy. The two test combinations include Topopah Spring tuff reacted with $\mathrm{NaHCO}_{3}$ solution and diesel fuel for 76 days at $200^{\circ} \mathrm{C}$ and 70 bars, and Fibercrete ${ }^{\mathrm{TM}}$ and Topopah Spring tuff reacted with $\mathrm{NaHCO}_{3}$ solution and diesel fuel for 79 days at $200^{\circ} \mathrm{C}$ and 70 bars. Reactions were facilitated in reaction vessels placed in an autoclave. Solution $\mathrm{pH}$ was measured at room temperatures and aqueous samples were analyzed for cations via ICP-AES. The initial and final solid materials (cement and tuff) were analyzed with XRD and SEM. Solution $\mathrm{pH}$ decreased slightly during the experiments and became more alkaline in waters that reacted with cement. Silica concentrations increase rapidly during the first 20 days, then reach a stable level for the duration of the test. Silica concentrations were double those measured in non-tuff experiments. Aluminum and potassium concentrations decreased over time, while calcium concentrations steadily increased. Iron $\left(\mathrm{Fe}^{3+}\right)$ and magnesium concentrations remained slightly above the detection limit. With respect to the analysis of the Topopah Spring tuff, XRD analyses detected no difference in the mineralogy of reacted and unreacted tuff. Three precipitates were found formed on the Topopah Spring tuff, Ca-silicate, calcite (rhombs crystals habit), and a silica rich matrix covering the surface.

The final experiment to be summarized in this section compares experimental results of crushed quartz and Topopah Spring tuff dissolution at $240^{\circ} \mathrm{C}$ in a plug-flow reactor with results obtained from reactive transport simulation software (Johnson et al. 1998). Crushed quartz and Topopah Spring tuff were loaded in separate plug-flow reactors with deionized water under fully saturated conditions. Effluent from the crushed quartz plug-flow reactor was analyzed for silica only while effluent from the reactor loaded with tuff was analyzed for silica, sodium, aluminum, potassium, calcium, magnesium, iron, and manganese. In both cases, the effluent concentrations were monitored throughout the test duration. The plug-flow reactor test containing quartz lasted for 2 weeks and reached steady state concentrations after 16.2 hours. The test containing tuff was carried on for 36 days and reached steady state concentrations in 4 days. Pre- and post-test materials were analyzed using SEM techniques to distinguish dissolution/precipitation features. SEM images of reacted tuff grains show clear evidence of feldspar and silica dissolution. Only minor evidences of secondary-minerals were observed at the outlet of the tuff plug-flow reactor in the form of silica spheres and calcium-rich clay minerals. The simulation software package 
OS3D/GIMRT was used to model the plug-flow reactor results based loosely on the transition state theory and a linear rate law. With respect to tuff dissolution, experimental and model effluent sodium, aluminum, and potassium concentrations agreed to within $3 \%$, and silica and calcium agreed to within $15 \%$. There was a difference in the time required to reach steady-state conditions. The model reached steady state in about 26 days, compared to 4 days observed in the plug-flow reactor experiment. 


\section{SUMMARY}

The column experiments demonstrated the capability of a boiling, closed loop reflux system to cause observable redistribution of minerals from the upper parts of the system to the boiling zone at the base of the column. The thermal hydraulic performance of the column is as expected, essentially forming a closed loop boiling/condensing constant temperature system that loses little water mass over the test duration. Because of the variety of mineral phases present, the chemical system resulting from the boiling-reflux process is quite complicated. The experiment produced a complex but quantitative assessment of the solution chemistry in the boiling zone that can be used for validating geochemical and thermal/hydrologic models.

The following general results are observed:

- Once the column reached steady operating conditions (typically within six hours after initiation of heating) the entire tuff fill was essentially at the water boiling temperature. The overall thermal gradient in the column was approximately $78 \mathrm{C}$ per meter, with almost the entire drop occurring very near the cooling cap.

- The boiling reflux system in contact with Topopah Spring middle nonlithophysal tuff, simulated by the column experiments, produced observable redistribution of mineral matter, resulting in the precipitation of primarily amorphous silica and opal-CT within the boiling zone.

- The fluid chemistry developed in the column experiment is a strongly alkaline solution, with a pH greater than 9 and stabilizing at values above 10.01 , suggesting the $\mathrm{pH}$ is likely being controlled by the carbonate system.

- Analysis of the solution composition from the boiling zone in Column Test 3 indicates that the solution is saturated with respect to one or more silica minerals early in the test. This observation is consistent with the petrographic observations and QXRD analyses of secondary mineral deposits.

- Analysis of the column air/vapor mixture indicated much higher than ambient carbon dioxide concentrations in the air (as high as 14.73\%). However, the estimated (non-Q) air fraction in the column is much lower than expected (on the order of $4 \mathrm{e}-3$ to $8 \mathrm{e}-4$ ) and the resulting range of $\mathrm{CO}_{2}$ partial pressures (also estimated, hence non-Q) range from 0.04573 to $5.085 \mathrm{~Pa}$.

- The total mass of secondary mineralization from the Column Test 3 experiment (2357.8-hour duration) was estimated at about 100 grams, or approximately 1.02 grams per day. Analysis of the water mass balance of the column showed the reflux rate of water through the column of 9.718 liters per day. Consequently, the ratio of the mass of secondary mineralization to reflux water mass is approximately $1 / 10,000$.

- The air permeability distribution measured pre- and post-test indicated measurable decreases in the top and bottom lifts, with the balance of the column showing imperceptible changes. The very bottom of the column was so filled with secondary 
mineralization that a permeability measurement was not possible with the given test configuration.

Readers are advised that the use of this technical report and its associated data are restricted to the conditions and parameters under which this test has been conducted. These results cannot be readily extrapolated to repository processes, and are intended solely as an experimental data set that can be used to validate geochemical and thermal/hydrologic models. 


\section{ACKNOWLEDGMENTS}

The Principal Investigator would like to acknowledge the major contribution of Zane Walton in the execution of this test program and final documentation of the results. Additional, significant support was provided by Mark Anderson and Tom Kendrick in the initial assembly and test startup, Linda Croom for document preparation and formatting, and Neva Mason for product QA support.

The authors would like to thank . Schon Levy, Los Alamos National Laboratory EES-6, Hydrology, Geology and Geochemistry Group, for performing XRD and SEM analyses, and for contributing to the sections on mineralogical analysis; Laura Wolfsberg and Catherine Jones, Los Alamos National Laboratory E-ET, Environmental Technologies Group, for liquid sample analysis; Fred Homuth, Troy Williams, and Bob Sievert, TCO for data system programming support, and data management; Asha Kalia for data submittals; Roy Johnston, Sandia National Laboratory, for experimental support; Norman Kramer for hardware acquisition and document review; Ernie Hardin for technical guidance, and Chris Tunley, Bechtel, Nevada Standards and Calibration Laboratory, for performing instrument calibrations. 
INTENTIONALLY LEFT BLANK 


\section{REFERENCES}

\subsection{DOCUMENTS CITED}

Belform Insulation 2000. "Koolphen K Technical Data." [London, Ontario, Canada]: Belform Insulation. Accessed December 18, 2000. TIC: 249204. http://www.belform.com/Products/kool_tech.htm.

BSC (Becthel SAIC Company) 2001. Technical Work Plan for: Subsurface Performance Testing For License Application (LA) For the Fiscal Year 2001. TWP-EBS-MD-000009 REV 03. Las Vegas, Nevada: Becthel SAIC Company. ACC: MOL.20010628.0246.

Carroll, S.A.; Alai, M.; ‘and Bruton, C.J. 1996. Experimental Investigation of Cement, Topopah Spring Tuff, and Water Interactions at $200^{\circ} \mathrm{C}$. UCRL-JC-128323. Livermore, California: Lawrence Livermore National Laboratory. ACC: MOL.19980501.0034.

CRWMS M\&O 1999a. Engineered Barrier Systems Performance Testing for SR and LA (12012383MT). Activity Evaluation, June 23, 1999. Las Vegas, Nevada: CRWMS M\&O. ACC: MOL.19990630.0473.

CRWMS M\&O 1999b. Request for Laboratory Bench-Scale Column Test Data, for Engineered Barrier System Thermal, Hydrological, Chemical Model Validation. Input Request EBS-EBS-99392.R. Las Vegas, Nevada: CRWMS M\&O. ACC: MOL.19991202.0105.

CRWMS M\&O 1999c. Engineered Barrier System Thermal/Hydrologic/Chemical (EBS THC) Column Testing. Development Plan TDP-EBS-ND-000003 REV 00. Las Vegas, Nevada: CRWMS M\&O. ACC: MOL.19990826.0104.

CRWMS M\&O 2000. EBS-Column Testing. Work Instruction Number TCO-WI-0043r01. Las Vegas, Nevada: CRWMS M\&O. ACC: MOL.20000927.0135.

DOE (U.S. Department of Energy) 2000. Quality Assurance Requirements and Description. DOE/RW-0333P, REV 10. Washington, D.C.: U.S. Department of Energy, Office of Civilian Radioactive Waste Management. ACC: MOL.20000427.0422.

Harrington, C.D. 1998. "Request for Approval of Milestone SP1410M4, "Mineralogic Products of the ESF Single Heater Test" by Schon Levy et al. and Database Transmission Package." Letter from C.D. Harrington (LANL) to L. Hayes (CRWMS M\&O), August 31, 1998, EES-13-08-98-179, with enclosures. ACC: MOL.20000110.0153.

Johnson, J.W.; Knauss, K.G.; Glassley, W.E.; DeLoach, L.D.; and Tompson, A.F.B. 1998. "Reactive Transport Modeling of Plug-Flow Reactor Experiments: Quartz and Tuff Dissolution at $240^{\circ}$ C." Journal of Hydrology, 209, 81-111. Amsterdam, The Netherlands: Elsevier Science. TIC: 240986. 
Kneafsey, T.J.; Apps, J.A.; and Sonnenthal, E.L. 2001. "Tuff Dissolution and Precipitation in a Boiling, Unsaturated Fracture." "Back to the Future-Managing the Back End of the Nuclear Fuel Cycle to Create a More Secure Energy Future," Proceedings of the $9^{\text {th }}$ International High-Level Radioactive Waste Management Conference (IHLRWM), Las Vegas, Nevada, April 29-May 3, 2001. La Grange Park, Illinois: American Nuclear Society. TIC: 247873.

Lowry, W. 2001a. EBS Column Test Field Notebook. Scientific Notebook SN-M\&O-SCI-016V1. ACC: MOL.20010207.0299.

Lowry, W. 2001b. EBS Column Test Field Notebook (Volume 2). Scientific Notebook SNM\&O-SCI-016-V2. ACC: MOL.20010523.0320.

Lowry, W. 2001c. EBS Column Test Field Notebook (Volume 3). Scientific Notebook SNM\&O-SCI-016-V3. ACC: MOL.20010906.0198.

Oversby, V.M. 1984. Reaction of the Topopah Spring Tuff with J-13 Well Water at $90^{\circ} \mathrm{C}$ and $150^{\circ} \mathrm{C}$. UCRL-53552. Livermore, California: Lawrence Livermore National Laboratory. ACC: NNA.19890905.0226.

Paces, J.B. and Peterman, Z.E. 2000. "Data on Contamination in Crushed Tuff (SPC00535357)." Letter from J.B. Paces and Z.E. Peterman (USGS) to J. Pye, March 28, 2000, with attachments. ACC: MOL.20000417.0730.

Peterman, Z.E. 2001. "Petrography of Crushed Tuff Used in Column Test." Memorandum from Z. E. Peterman (USGS) to N. Kramer, May 22, 2001. ACC: MOL.20010613.0183.

Pye, J.H. 1999. "Planning Guidance for THC Column Test." Interoffice correspondence from J.H. Pye (CRWMS M\&O) to Distribution, December 16, 1999. LV.EBSPT.JHP.12/99-009, with attachment. ACC: MOL.20010124.0332; MOL.19991202.0105.

Rimstidt, J.D. and Williamson, M.A. 1991. Vertical Thermal Gradient Experiment Results. Blacksburg, Virginia: Virginia Polytechnic Institute and State University, Department of Geological Sciences. TIC: 227029.

USGS (U.S. Geological Survey) 1969. Topographic Map of Las Vegas, Nevada; Arizona; California. Grid Zone Designation 11S. Quadrangle NJ 11-12. Denver, Colorado: U.S. Geological Survey. TIC: 241810.

Weast, R.C., ed. 1977. CRC Handbook of Chemistry and Physics. 58th Edition. Cleveland, Ohio: CRC Press. TIC: 242376.

Weast, R. C., ed. 1984. CRC Handbook of Chemistry and Physics. $65^{\text {th }}$ Edition. Boca Raton, Florida: CRC Press. TIC: 206666.

YMP (Yucca Mountain Site Characterization Project) 1998. Q-List. YMP/90-55Q, Rev. 5. Las Vegas, Nevada: Yucca Mountain Site Characterization Office. ACC: MOL.19980513.0132. 
YMP 2000a. Q-List. YMP/90-55Q, Rev. 6. Las Vegas, Nevada: Yucca Mountain Site Characterization Office. ACC: MOL.20000510.0177.

YMP 2000b. Sample Collection Report for Sample (SPC00562011) Collect by R.G. Kovach, March 30, 2000. [Las Vegas, Nevada]: Yucca Mountain Site Characterization Office. ACC: MOL.20000815.0013.

Zielinski, R.A. 1980. "Uranium in Secondary Silica: A Possible Exploration Guide.” Economic Geology, 75, 592-602.[Lancaster, Pennsylvania]: Economic Geology Publishing Company. TIC: 237418 .

Zielinski, R.A. 1982. "Uraniferous Opal, Virgin Valley, Nevada: Conditions of Formation and Implications for Uranium Exploration." Journal of Geochemical Exploration, 16, 197-216. Amsterdam, The Netherlands: Elsevier Scientific Publishing. TIC: 226039.

\subsection{CODES, STANDARDS, REGULATIONS, AND PROCEDURES}

AP-3.11Q, Rev. 2. Technical Reports. Washington, D.C.: U.S. Department of Energy, Office of Civilian Radioactive Waste Management. ACC: MOL.20010405.0010.

AP-SI.1Q, Rev. 3, ICN2, ECN1. Software Management. Washington, D.C.: U.S. Department of Energy, Office of Civilian Radioactive Waste Management. ACC: MOL.20011030.0598.

AP-SIII.1Q, Rev. 1, ICN1. Scientific Notebooks. Washington, D.C.: U.S. Department of Energy, Office of Civilian Radioactive Waste Management. ACC: MOL.20010905.0138.

AP-SV.1Q, Rev. 0, ICN2. Control of the Electronic Management of Information. Washington, D.C.: U.S. Department of Energy, Office of Civilian Radioactive Waste Management. ACC: MOL.20000831.0065.

ASTM (American Society for Testing and Materials) 1998. Annual Book of ASTM Standards. Section 4: Construction. Volume 04.08 Soil and Rock (I): D 420 - D 4914. West Conshohocken, Pennsylvania: American Society for Testing and Materials. TIC: 242992.

YMP-USGS-HP-23, R5. Collection and Field Analysis of Water Samples. [Denver, Colorado]: U.S. Geological Survey. ACC: MOL.19980608.0227.

\subsection{SOURCE DATA}

LA0106ZW831234.001. Alkalinity Data for the Engineered Barrier System Thermal-HydraulicChemical Column Test \#3. Submittal date: 06/12/2001.

LA0106ZW831234.002. Cation Data for the Engineered Barrier System Thermal-HydraulicChemical Column Test \#3. Submittal date: 06/25/2001. 
LA0106ZW831234.003. Potassium Data for the Engineered Barrier System Thermal-HydraulicChemical Column Test \#3. Submittal date: 06/25/2001.

LA0106ZW831234.004. Bromide Data for the Engineered Barrier System Thermal-HydraulicChemical Column Test \#3. Submittal date: 06/12/2001.

LA0106ZW831234.005. Chloride Data for the Engineered Barrier System Thermal-HydraulicChemical Column Test \#3. Submittal date: 06/12/2001.

LA0106ZW831234.006. Fluoride Data for the Engineered Barrier System Thermal-HydraulicChemical Column Test \#3. Submittal date: 06/12/2001.

LA0106ZW831234.007. Nitrate Data for the Engineered Barrier System Thermal-HydraulicChemical Column Test \#3. Submittal date: 06/12/2001.

LA0106ZW831234.008. Phosphate Data for the Engineered Barrier System Thermal-HydraulicChemical Column Test \#3. Submittal date: 06/12/2001.

LA0106ZW831234.009. Sulfate Data for the Engineered Barrier System Thermal-HydraulicChemical Column Test \#3. Submittal date: 06/12/2001.

LA0107SL831222.001. Mineralogy of EBS Thermal/Hydraulic/Chemical Column Test No. 3. Submittal date: 07/03/2001.

LA0108SL831225.001. Chemical and Textural Characteristics of Crushed Tuff from Therma1/Hydraulic/Chemical Column Test No. 3. Submittal date: 08/03/2001.

LA0110SL831225.001. Textural and Particle Characteristics from EBS Thermal/ Hydraulic/ Chemical Column Test Number 3. Submittal date: 10/31/2001.

MO0104EBSCTEGC.000. Engineered Barrier System Thermal-Hydraulic-Chemical Column Test No. 1 and Thermal-Hydraulic-Chemical Column Test No. 2 Analytical Results for Fluid Samples. Submittal date: 04/03/2001.

MO0106EBSCT3AP.004. Engineered Barrier System Thermal/Hydrologic/Chemical Column Test No. 3 Air Permeability Measurement Data. Submittal date: 06/06/2001.

MO0106EBSCT3PH.005. Engineered Barrier System Thermal-Hydraulic-Chemical Column Test No. $3 \mathrm{Ph}$ Measurement Results. Submittal date: 06/08/2001.

MO0106EBSCT3PH.006. Engineered Barrier System Thermal-Hydraulic-Chemical Column Test No. $3 \mathrm{Ph}$ Measurement Results. Submittal date: 06/13/2001.

MO0107EBSTHCT3.007. Engineered Barrier System Thermal/Hydraulic/Chemical Column Test No. 3 Process Data from September 18, 2000 to January 16, 2001. Submittal date: 07/16/2001. 
MO0109EBSCT3CD.010. Engineered Barrier System Therma1/Hydraulic/Chemical Column Test No. 3 Carbon Dioxide Measurement Results. Submittal date: 09/24/2001.

MO0109EBSCT3HD.008. Engineered Barrier System Thermal/Hydraulic/Chemical Column Test No. 3 Calculated Heat Removal Data from November 17, 2000 to January 12, 2001. Submittal date: 09/14/2001.

SN9908T0872799.004. Tabulated In-Drift Geometric and Thermal Properties Used in Drift-Scale Models for TSPA-SR (Total System Performance Assessment-Site Recommendation). Submittal date: 08/30/1999. 
Table 1. Column Test 3 Chronology

\begin{tabular}{|c|c|c|c|}
\hline Date & Time & Event & Comments \\
\hline $5 / 10 / 00$ & & Column filled with crushed tuff. & SPC 562011 \\
\hline $5 / 10 / 00$ & & Air permeability measurement performed. & \\
\hline $7 / 5 / 00$ & & Line conditioner installed on chiller. & \\
\hline $9 / 18 / 00$ & $16: 35$ & $\begin{array}{l}\text { Column heater energized to nominal } 400 \\
\text { watts. }\end{array}$ & CT3 start date \\
\hline $9 / 18 / 00$ & $20: 30$ & $\begin{array}{l}60 \propto \text { liquid sample taken from saturated zone } \\
\text { for cation, anion, and } \mathrm{pH} \text { analysis. } 60 \mathrm{cc} \text { liquid } \\
\text { sample taken from supply water reservoir. }\end{array}$ & \\
\hline $9 / 19 / 00$ & & $\begin{array}{l}\text { Insulation blanket installed. Gas samples } \\
\text { collected. }\end{array}$ & \\
\hline $9 / 19 / 00$ & $15: 20$ & $\begin{array}{l}60 \mathrm{cc} \text { liquid sample taken from saturated zone } \\
\text { for cation, anion, and } \mathrm{pH} \text { analysis. } 60 \mathrm{cc} \text { liquid } \\
\text { sample taken from supply water reservoir. }\end{array}$ & \\
\hline $9 / 19 / 00$ & $10: 56$ & RTD01 failed. & Replaced with CT1-RTD04. \\
\hline $9 / 20 / 00$ & & Gas samples collected. & \\
\hline $9 / 25 / 00$ & & $\begin{array}{l}\text { Preheat cylinder leak repair. } \\
\text { Gas samples collected. }\end{array}$ & \\
\hline $9 / 25 / 00$ & $15: 40$ & $\begin{array}{l}60 \mathrm{cc} \text { liquid sample taken from saturated zone } \\
\text { for cation, anion, and } \mathrm{pH} \text { analysis. }\end{array}$ & \\
\hline $9 / 26 / 00$ & 07:02 & $\begin{array}{l}\text { DAS offline - no data logged from this time } \\
\text { until } 9 / 27 / 0000: 02 \text {. }\end{array}$ & \\
\hline $9 / 26 / 00$ & $08: 20$ & Heat input readjusted to 400 watts & \\
\hline $9 / 26 / 00$ & & Preheat cylinder replaced. & \\
\hline $9 / 26 / 00$ & 19:21 & RTD04 failed. & Replaced with CT1-RTD08. \\
\hline $9 / 26 / 00$ & $19: 30$ & RTD03 failed. & Replaced with CT1-RTD06 \\
\hline $9 / 27 / 00$ & $00: 02$ & DAS online - begin collecting data. & \\
\hline $9 / 27 / 00$ & $09: 20$ & Heat input adjusted to 400 watts & \\
\hline $9 / 27 / 00$ & $14: 10$ & Added DI water to supply water tank (SCA1) & \\
\hline $9 / 29 / 00$ & $12: 02$ & $\begin{array}{l}\text { Heater element malfunction, column heater } \\
\text { de-energized }\end{array}$ & $\begin{array}{l}\text { Failed heater power } \\
\text { connection }\end{array}$ \\
\hline $10 / 02 / 00$ & 13:25 & $\begin{array}{l}60 \mathrm{cc} \text { liquid sample taken from saturated zone, } \\
\text { column in non -heated condition }\end{array}$ & \\
\hline $10 / 05 / 00$ & $14: 00$ & Collected gas sample & \\
\hline $10 / 5 / 00$ & $14: 05$ & $\begin{array}{l}\text { Column heater re-energized to nominal } 450 \\
\text { watts }\end{array}$ & New heater element installed \\
\hline $10 / 5 / 00$ & 17:17 & $\begin{array}{l}60 \mathrm{cc} \text { liquid sample collected from supply water } \\
\text { tank }\end{array}$ & \\
\hline $10 / 5 / 00$ & $17: 50$ & $\begin{array}{l}120 \text { cc liquid sample taken from saturated } \\
\text { zone for cation, anion, and } \mathrm{pH} \text { analysis. }\end{array}$ & \\
\hline $10 / 6 / 00$ & & $\begin{array}{l}\text { Increasing SCA1 weight and biological matter } \\
\text { found in supply water tank. }\end{array}$ & $\begin{array}{l}\text { Filter system installed in supply } \\
\text { water tank to filter out } \\
\text { biological matter. }\end{array}$ \\
\hline $10 / 6 / 00$ & $10: 00$ & $\begin{array}{l}30 \propto \text { liquid sample taken from saturated zone } \\
\text { for } \mathrm{pH} \text { analysis }\end{array}$ & \\
\hline $10 / 9 / 00$ & $00: 17$ & $\begin{array}{l}\text { Chiller malfunction, column heater de- } \\
\text { energized }\end{array}$ & Bad fuse connection \\
\hline $10 / 9 / 00$ & $19: 48$ & $\begin{array}{l}\text { Chiller repaired, column heater re-energized to } \\
\text { nominal } 475 \text { watts }\end{array}$ & $\begin{array}{l}\text { Heater reached } 475 \text { watts } \\
\text { naturally, did not adjust power } \\
\text { input, only re-energized it }\end{array}$ \\
\hline $10 / 10 / 00$ & $11: 33$ & $\begin{array}{l}\text { Drained, rinsed, and replaced DI water in } \\
\text { supply water tank. }\end{array}$ & Completed at 11:33. \\
\hline $10 / 11 / 00$ & $14: 30$ & $\begin{array}{l}60 \mathrm{cc} \text { liquid sample taken from saturated zone } \\
\text { for cation, anion, and } \mathrm{pH} \text { analysis. }\end{array}$ & \\
\hline
\end{tabular}


Table 1. Column Test 3 Chronology (Continued)

\begin{tabular}{|c|c|c|c|}
\hline Date & Time & Event & Comments \\
\hline $10 / 11 / 00$ & $16: 00$ & Collected gas sample. & \\
\hline $10 / 18 / 00$ & $12: 10$ & Collected gas sample. & \\
\hline $10 / 18 / 00$ & 15:09 & $\begin{array}{l}\text { 60cc liquid sample taken from saturated zone } \\
\text { for cation, anion, and } \mathrm{pH} \text { analysis. }\end{array}$ & \\
\hline $10 / 23 / 00$ & 12:02 & Heater power interrupted. & $\begin{array}{l}\text { Due to rough handling of latching } \\
\text { relay box. }\end{array}$ \\
\hline $10 / 23 / 00$ & $14: 20$ & $\begin{array}{l}\text { Column heater re-energized to nominal } 400 \\
\text { Watts. }\end{array}$ & $\begin{array}{l}\text { Fuse replaced in temperature } \\
\text { controller. }\end{array}$ \\
\hline $10 / 25 / 00$ & $09: 42$ & Gas sample collected. & \\
\hline $10 / 25 / 00$ & $12: 48$ & $\begin{array}{l}60 \mathrm{cc} \text { liquid sample taken from saturated zone } \\
\text { for cation, anion, and } \mathrm{pH} \text { analysis. }\end{array}$ & \\
\hline $11 / 1 / 00$ & $13: 40$ & $\begin{array}{l}60 \mathrm{cc} \text { liquid sample taken from saturated zone } \\
\text { for cation, anion, and } \mathrm{pH} \text { analysis. }\end{array}$ & \\
\hline $11 / 1 / 00$ & $14: 50$ & $\begin{array}{l}60 \mathrm{cc} \text { liquid sample taken from saturated zone } \\
\text { for cation, anion, and } \mathrm{pH} \text { analysis. }\end{array}$ & \\
\hline $11 / 8 / 00$ & $12: 57$ & $\begin{array}{l}60 \mathrm{cc} \text { liquid sample taken from saturated zone } \\
\text { for cation, anion, and } \mathrm{pH} \text { analysis. }\end{array}$ & \\
\hline $11 / 15 / 00$ & $11: 35$ & Collected gas sample. & \\
\hline $11 / 16 / 00$ & $12: 00$ & Disconnected CT1-FLO1 to check calibration & \\
\hline $11 / 16 / 00$ & 11:00 & Heater power interrupted. & $\begin{array}{l}\text { Cooling cap temperature rose } \\
\text { while removing cooling water flow } \\
\text { - meter for calibration check. Did } \\
\text { not immediately notice it } \\
\text { interrupted heater power. }\end{array}$ \\
\hline $11 / 16 / 00$ & 13:00 & $\begin{array}{l}\text { Column heater re-energized to nominal } 400 \\
\text { Watts. }\end{array}$ & $\begin{array}{l}\text { Realized heater was off and } \\
\text { reinitiated power. }\end{array}$ \\
\hline $11 / 16 / 00$ & $21: 15$ & $\begin{array}{l}\text { Verified correct calibration of CT1-FLO1 and } \\
\text { discovered DAS was responsible for } \\
\text { erroneous flow data. }\end{array}$ & $\begin{array}{l}\text { Adjusted DAS and reconnected } \\
\text { flowmeter - flow data accurate } \\
\text { now. }\end{array}$ \\
\hline $11 / 17 / 00$ & 12:00 & Heater power interrupted. & $\begin{array}{l}\text { Planned weekend shutdown to } \\
\text { accommodate planned power } \\
\text { outages. }\end{array}$ \\
\hline $11 / 20 / 00$ & $08: 43$ & Gas sample collected. & \\
\hline $11 / 20 / 00$ & $09: 25$ & $\begin{array}{l}120 \mathrm{cc} \text { liquid sample taken from saturated zone } \\
\text { for cation, anion, and } \mathrm{pH} \text { anaysis. }\end{array}$ & \\
\hline $11 / 20 / 00$ & $11: 02$ & $\begin{array}{l}\text { Column heater re-energized to nominal } 400 \\
\text { Watts. }\end{array}$ & Restart after planned interruption. \\
\hline $11 / 20 / 00$ & $18: 37$ & Heater power interrupted. & Chiller malfunction. \\
\hline $11 / 21 / 00$ & 08:17 & $\begin{array}{l}\text { Column heater re-energized to nominal } 400 \\
\text { watts. }\end{array}$ & Fuse replaced in chiller. \\
\hline $11 / 21 / 00$ & $14: 30$ & $\begin{array}{l}120 \mathrm{cc} \text { liquid sample taken from saturated zone } \\
\text { for cation, anion, and } \mathrm{pH} \text { anaysis. }\end{array}$ & \\
\hline $11 / 22 / 00$ & $11: 07$ & Heater power interrupted. & Chiller malfunction. \\
\hline $11 / 27 / 00$ & $14: 02$ & $\begin{array}{l}\text { Column heater re-energized to nominal } 400 \\
\text { watts. }\end{array}$ & Fuse replaced in chiller. \\
\hline $11 / 27 / 00$ & $18: 02$ & Heater power interrupted. & Chiller malfunction. \\
\hline $11 / 29 / 00$ & 13:37 & $\begin{array}{l}\text { Column heater re-energized to nominal } 400 \\
\text { watts. }\end{array}$ & Circuit board replaced in chiller. \\
\hline
\end{tabular}


Table 1. Column Test 3 Chronology (Continued)

\begin{tabular}{|c|c|c|c|}
\hline Date & Time & Event & Comments \\
\hline $12 / 6 / 00$ & $10: 25$ & Gas sample collected. & $\begin{array}{l}\text { Begin using gravity water trap } \\
\text { during gas collection. Volume of } \\
\text { water collected is unkown. }\end{array}$ \\
\hline $12 / 6 / 00$ & $12: 30$ & $\begin{array}{l}\text { 60cc liquid sample taken from saturated zone } \\
\text { for cation, anion, and } \mathrm{pH} \text { analysis. }\end{array}$ & \\
\hline $12 / 8 / 00$ & $12: 00$ & Time stamp & \\
\hline $12 / 18 / 00$ & $09: 20$ & $\begin{array}{l}70 \mathrm{cc} \text { liquid sample taken from saturated zone } \\
\text { for cation, anion, and } \mathrm{pH} \text { analysis. }\end{array}$ & \\
\hline $12 / 18 / 00$ & $16: 26$ & Adjusted air flow rate to $20 \mathrm{cc} / \mathrm{min}$. & $\begin{array}{l}\text { Begin overpressure test, see } \\
\text { pages } 139-141 \text { scientific } \\
\text { notebook (Lowry 2001b). }\end{array}$ \\
\hline $12 / 18 / 00$ & 17:04 & Adjusted air flow rate to $40 \mathrm{cc} / \mathrm{min}$. & \\
\hline $12 / 18 / 00$ & $17: 37$ & $\begin{array}{l}\text { Adjusted air flow rate to } 60 \mathrm{cc} / \mathrm{min} \text {, and } \\
\text { maintained this flow overnight. }\end{array}$ & \\
\hline $12 / 18 / 00$ & $18: 30$ & Heater power interrupted. & $\begin{array}{l}\text { Inspection of latching relay } \\
\text { system. }\end{array}$ \\
\hline $12 / 18 / 00$ & $18: 45$ & $\begin{array}{l}\text { Column heater re-energized to nominal } 400 \\
\text { watts. }\end{array}$ & Completed above inspection \\
\hline $12 / 19 / 00$ & $09: 35$ & $\begin{array}{l}\text { 80cc liquid sample taken from saturated zone } \\
\text { for cation, anion, and } \mathrm{pH} \text { analysis. }\end{array}$ & \\
\hline $12 / 19 / 00$ & $09: 40$ & Gas sample collected & $\begin{array}{l}\text { Approx. } 100 \mathrm{cc} \text { water collected in } \\
\text { trap. }\end{array}$ \\
\hline $12 / 19 / 00$ & $11: 54$ & Returned air flow rate to nominal $16 \mathrm{cc} / \mathrm{min}$. & End overpressure test. \\
\hline $12 / 22 / 00$ & $12: 00$ & Time Stamp & \\
\hline $1 / 4 / 01$ & $08: 30$ & $\begin{array}{l}\text { During sampling event, found sampling valve } \\
\text { closed. Column water was not being } \\
\text { replenished and the level was well below } \\
\text { sampling port \#1. }\end{array}$ & $\begin{array}{l}\text { Sampling valve was opened to } \\
\text { allow column water to refill before } \\
\text { drawing a liquid sample. }\end{array}$ \\
\hline $1 / 4 / 01$ & 13:15 & $\begin{array}{l}60 \mathrm{cc} \text { liquid sample taken from saturated zone } \\
\text { for cation, anion, and } \mathrm{pH} \text { analysis. }\end{array}$ & \\
\hline $1 / 5 / 01$ & $10: 26$ & $\begin{array}{l}\text { Column bottom temperature (Channel 4) was } \\
\text { rising near the set point of } 205^{\circ} \mathrm{C} \text {. Changed } \\
\text { setting to } 210^{\circ} \mathrm{C} \text { to maintain heat energy } \\
\text { through cooling cap test. }\end{array}$ & \\
\hline $1 / 8 / 01$ & $05: 13$ & Gas sample collected. & $\begin{array}{l}\text { Approx. 440cc water collected in } \\
\text { trap }\end{array}$ \\
\hline $1 / 8 / 01$ & 08:30 & $\begin{array}{l}60 \mathrm{cc} \text { liquid sample taken from saturated zone } \\
\text { for cation, anion, and } \mathrm{pH} \text { analysis. }\end{array}$ & \\
\hline $1 / 8 / 01$ & 09:47 & Adjusted chiller bath temperature to $25^{\circ} \mathrm{C}$. & $\begin{array}{l}\text { Begin cooling cap temperature } \\
\text { test, see pages 148-152 (Lowry } \\
2001 \mathrm{c} \text { ). }\end{array}$ \\
\hline $1 / 9 / 01$ & 07:04 & Gas sample collected. & $\begin{array}{l}\text { Approx. } 175 \mathrm{cc} \text { water collected in } \\
\text { trap }\end{array}$ \\
\hline $1 / 9 / 00$ & $11: 19$ & Adjusted chiller bath temperature to $40^{\circ} \mathrm{C}$. & \\
\hline $1 / 10 / 01$ & $06: 57$ & Gas sample collected. & $\begin{array}{l}\text { Approx. } 225 \mathrm{cc} \text { water collected in } \\
\text { trap }\end{array}$ \\
\hline $1 / 10 / 01$ & $12: 59$ & $\begin{array}{l}\text { Adjusted chiller bath temperature to nominal } \\
10^{\circ} \mathrm{C} \text {. }\end{array}$ & $\begin{array}{l}\text { End cooling cap temperature } \\
\text { test. }\end{array}$ \\
\hline $1 / 12 / 01$ & $11: 40$ & Column heater power turned off. & Channel 4 temperature at $108^{\circ} \mathrm{C}$ \\
\hline $1 / 16 / 01$ & $08: 47$ & $\begin{array}{l}120 c c \text { liquid sample taken from saturated zone } \\
\text { for cation, anion, and } \mathrm{pH} \text { analysis. }\end{array}$ & \\
\hline $1 / 16 / 01$ & 09:00 & $\begin{array}{l}\text { Turned of chiller and all external devices. } \\
\text { Drained column water. }\end{array}$ & $\begin{array}{l}\text { Collected } 684.4 \mathrm{cc} \text { water from } \\
\text { column. }\end{array}$ \\
\hline $1 / 16 / 01$ & $12: 15$ & Start column drying with ambient air. & $\begin{array}{l}\text { Drying air flow rate approximately } \\
20 \text { sipm. }\end{array}$ \\
\hline
\end{tabular}


Table 1. Column Test 3 Chronology (Continued)

\begin{tabular}{|c|c|l|l|}
\hline Date & Time & \multicolumn{1}{|c|}{ Event } & Comments \\
\hline $1 / 25 / 01$ & $\begin{array}{l}\text { Before } \\
12: 00\end{array}$ & $\begin{array}{l}\text { Performed post-test air permeability } \\
\text { measurements. }\end{array}$ & \\
\hline $1 / 25 / 01$ & $\begin{array}{l}\text { After } \\
12: 00\end{array}$ & $\begin{array}{l}\text { Unloaded column tuff and identified lift } \\
\text { samples. }\end{array}$ & \\
\hline
\end{tabular}

Source: Lowry 2001c, pp. 7-11. 
Table 2. EBS Column Test 3 Instrument Specifications

\begin{tabular}{|c|c|c|c|c|c|}
\hline $\begin{array}{c}\text { Data } \\
\text { System } \\
\text { Identifier }\end{array}$ & Description & $\begin{array}{c}\text { Sensor } \\
\text { Serial } \\
\text { Number }\end{array}$ & Sensor Model & $\begin{array}{l}\text { Recorded } \\
\text { Units }(x)\end{array}$ & $\begin{array}{c}\text { Converted } \\
\text { Units (y) }\end{array}$ \\
\hline CT1-SCA1 & Supply water & $\begin{array}{c}20018-2 / \\
321686\end{array}$ & GSE-4456 & Volts & Kilograms \\
\hline CT1-SCA2 & $\begin{array}{c}\text { Vent } \\
\text { Condensate }\end{array}$ & $\begin{array}{c}20018-1 / \\
321687\end{array}$ & GSE-4456 & Volts & Kilograms \\
\hline CT1-PWR1 & Input power & 9100320 & Ohio Scientific W-001X5Y52T & Volts & Watts \\
\hline CT1-EN1 & Input energy & 9100320 & Ohio Scientific \#W-001X5Y52T & Pulses & Watt-hours \\
\hline CT1-FLO1 & $\begin{array}{l}\text { Cooling cap } \\
\text { water flow }\end{array}$ & & Cole Parmer \#P-32250-00 & Pulses & Liters \\
\hline CT1-FLO2 & Inj. Air flow rate & 3252 & Cole Parmer \#P-32915-58 & Volts & Stand. $\mathrm{ml} / \mathrm{min}$ \\
\hline CT1-RTD1 & Column temp. & 367 & Omega $1 \mathrm{PT} 100 \mathrm{~K} 2515$ & Ohms & Degrees C \\
\hline CT1-RTD2 & Column temp. & 363 & Omega 1 PT 100 K2515 & Ohms & Degrees C \\
\hline CT1-RTD3 & Column temp. & 358 & Omega $1 \mathrm{PT} 100 \mathrm{~K} 2515$ & Ohms & Degrees C \\
\hline CT1-RTD4 & Column temp. & 360 & Omega $1 \mathrm{PT} 100 \mathrm{~K} 2515$ & Ohms & Degrees C \\
\hline CT1-RTD5 & Column temp. & 354 & Omega 1 PT $100 \mathrm{~K} 2515$ & Ohms & Degrees C \\
\hline CT1-RTD6 & Column temp. & 352 & Omega $1 \mathrm{PT} 100 \mathrm{~K} 2515$ & Ohms & Degrees C \\
\hline CT1-RTD7 & Column temp. & 353 & Omega $1 \mathrm{PT} 100 \mathrm{~K} 2515$ & Onms & Degrees C \\
\hline CT1-RTD8 & Column temp. & 351 & Omega 1 PT 100 K2515 & Ohms & Degrees C \\
\hline CT1-RTD9 & Column temp. & 361 & Omega $1 \mathrm{PT} 100 \mathrm{~K} 2515$ & Ohms & Degrees C \\
\hline $\begin{array}{c}\text { CT1- } \\
\text { RTD10 }\end{array}$ & Column temp. & 350 & Omega $1 \mathrm{PT} 100 \mathrm{~K} 2515$ & Ohms & Degrees C \\
\hline $\begin{array}{c}\text { CT1- } \\
\text { RTD11 }\end{array}$ & $\begin{array}{l}\text { Cooling cap } \\
\text { temp. }\end{array}$ & 349 & Omega $1 \mathrm{PT} 100 \mathrm{~K} 2515$ & Ohms & Degrees C \\
\hline $\begin{array}{c}\text { CT1- } \\
\text { RTD12 } \\
\end{array}$ & Column temp. & 348 & Omega 1 PT 100 K2515 & Ohms & Degrees C \\
\hline $\begin{array}{c}\text { CT1- } \\
\text { RTD13 }\end{array}$ & Column temp. & 355 & Omega $1 \mathrm{PT} 100 \mathrm{~K} 2515$ & Ohms & Degrees C \\
\hline $\begin{array}{c}\text { CT1- } \\
\text { RTD15 } \\
\end{array}$ & Column temp. & 356 & Omega 1 PT 100 K2515 & Ohms & Degrees C \\
\hline $\begin{array}{c}\text { CT1- } \\
\text { RTD16 } \\
\end{array}$ & $\begin{array}{l}\text { Cooling cap } \\
\text { inlet temp. }\end{array}$ & 364 & Omega $1 \mathrm{PT} 100 \mathrm{~K} 2515$ & Ohms & Degrees C \\
\hline $\begin{array}{c}\text { CT1- } \\
\text { RTD17 }\end{array}$ & $\begin{array}{l}\text { Cooling cap } \\
\text { outlet temp. }\end{array}$ & 365 & Omega 1 PT 100 K2515 & Ohms & Degrees C \\
\hline
\end{tabular}

Source: Lowry 2001b, p. 2. 
Table 3. Samples Provided for Petrographic Analysis

\begin{tabular}{|c|c|l|}
\hline SMF Number & USGS Number & \multicolumn{1}{|c|}{ Sample Description } \\
\hline 00573024 & KYF10 & Indurated tuff from Lift 1 \\
\hline 00573024 & KYF11 & Indurated tuff from Lift 1 \\
\hline 00573027 & KYF1 & Granular tuff from Lift 10 \\
\hline 00573029 & KYF2 & Granular tuff from Lift 8 \\
\hline 00573032 & KYF3 & Granular tuff from Lift 5 \\
\hline 00573035 & KYF4 & Granular tuff from Lift 2 \\
\hline 00573036 & KYF5 & Granular tuff from Lift 1 \\
\hline 00573036 & KYF6 & Granular tuff from Lift 1 \\
\hline 00573037 & KYF7 & Granular tuff from Lift 1 \\
\hline 00573037 & KYF8 & Granular tuff from Lift 1 \\
\hline 00573040 & KYF9 & $\begin{array}{l}\text { Pre-test crushed Topopah Spring middle } \\
\text { nonlithophysal tuff (unwashed) }\end{array}$ \\
\hline 00573041 & KYF12 & Cermenting material from column bottom (Lift 1) \\
\hline
\end{tabular}

Source: Peterman 2001, p. 2; Lowry 2001c, p. 69.

Table 4. Mineralogic Analysis Sample Descriptions

\begin{tabular}{|l|l|l|}
\hline \multicolumn{1}{|c|}{ SMF Number } & LANL Number & \multicolumn{1}{|c|}{ Sample Description } \\
\hline SPC 00562011 & LANL 3720 & $\begin{array}{l}\text { Pre-test crushed Topopah Spring middle } \\
\text { nonlithophysal tuff (washed) }\end{array}$ \\
\hline SPC 573047 & LANL 3633p1 & $\begin{array}{l}\text { Pre-test crushed Topopah Spring middle } \\
\text { nonlithophysal tuff (unwashed) }\end{array}$ \\
\hline SPC 573047 & LANL 3633p2 & $\begin{array}{l}\text { Pre-test crushed Topopah Spring middle } \\
\text { nonlithophysal tuff (unwashed) }\end{array}$ \\
\hline SPC 573047 & LANL 3633p3 & $\begin{array}{l}\text { Pre-test crushed Topopah Spring middle } \\
\text { nonlithophysal tuff (unwashed) }\end{array}$ \\
\hline SPC 57304 & LANL 3633p4 & $\begin{array}{l}\text { Pre-test crushed Topopah Spring middle } \\
\text { nonlithophysal tuff (unwashed) }\end{array}$ \\
\hline SPC 573047 & LANL 3633p5 & $\begin{array}{l}\text { Pre-test crushed Topopah Spring middle } \\
\text { nonlithophysal tuff (unwashed) }\end{array}$ \\
\hline SPC 573042 & LANL 3628p1 & Post-test crushed tuff from lift 10 \\
\hline SPC 573042 & LANL 3628p2 & Post-test crushed tuff from lift 10 \\
\hline SPC 573042 & LANL 3628p3 & Post-test crushed tuff from lift 10 \\
\hline SPC 573042 & LANL 3628p4 & Post-test crushed tuff from lift 10 \\
\hline SPC 573042 & LANL 3628p5: & Post-test crushed tuff from lift 10 \\
\hline SPC 573026 & LANL 3626p1 & Cementing material from lift 1 \\
\hline SPC 573039 & LANL 3627p1 & Cementing material from lift 1 \\
\hline SOur L0w7 2001C,p. 69 & &
\end{tabular}

Source: Lowry 2001c, p. 69. 
Table 5. EBS Column Test No. 3 Permeability Pretest Performed on 5/10/00

\begin{tabular}{|c|c|c|}
\hline $\begin{array}{c}\text { Distance from } \\
\text { top heater disk } \\
(\mathbf{m})\end{array}$ & $\begin{array}{c}\text { Air } \\
\text { Permeability } \\
\left(\mathbf{m}^{\wedge} \mathbf{2}\right)\end{array}$ & $\begin{array}{c}\text { Air Permeability } \\
\text { (Darcies) }\end{array}$ \\
\hline 0.09715 & $7.234 \mathrm{E}-09$ & 7381 \\
\hline 0.18985 & $5.229 \mathrm{E}-09$ & 5336 \\
\hline 0.28255 & $4.585 \mathrm{E}-09$ & 4678 \\
\hline 0.37525 & $6.101 \mathrm{E}-09$ & 6226 \\
\hline 0.46795 & $5.219 \mathrm{E}-09$ & 5326 \\
\hline 0.56065 & $5.230 \mathrm{E}-09$ & 5336 \\
\hline 0.65335 & $7.293 \mathrm{E}-09$ & 7441 \\
\hline 0.74605 & $6.089 \mathrm{E}-09$ & 6214 \\
\hline 0.83875 & $1.218 \mathrm{E}-08$ & 12427 \\
\hline Mean & $6.573 \mathrm{E}-09$ & 6707 \\
\hline
\end{tabular}

Source: Lowry 2001b, pp. 27, 159; DTN\#MO0106EBSCT3AP.004.

Table 6. EBS Column Test No. 3 Permeability Post Test Performed on 1/25/01

\begin{tabular}{|c|c|c|}
\hline $\begin{array}{c}\text { Distance from top } \\
\text { heater disk }(\mathbf{m})\end{array}$ & $\begin{array}{c}\text { Air Permeability } \\
\left(\mathbf{m}^{\wedge} \mathbf{2}\right)\end{array}$ & $\begin{array}{c}\text { Air Permeability } \\
\text { (Darcies) }\end{array}$ \\
\hline 0.09715 & $4.005 \mathrm{E}-09$ & 4086 \\
\hline 0.18985 & $4.506 \mathrm{E}-09$ & 4598 \\
\hline 0.28255 & $4.505 \mathrm{E}-09$ & 4597 \\
\hline 0.37525 & $6.007 \mathrm{E}-09$ & 6130 \\
\hline 0.46795 & $4.506 \mathrm{E}-09$ & 4598 \\
\hline 0.56065 & $5.149 \mathrm{E}-09$ & 5254 \\
\hline 0.65335 & $6.008 \mathrm{E}-09$ & 6130 \\
\hline 0.74605 & $6.008 \mathrm{E}-09$ & 6130 \\
\hline 0.83875 & $9.012 \mathrm{E}-09$ & 9196 \\
\hline Mean & $5.523 \mathrm{E}-09$ & 5636 \\
\hline
\end{tabular}

Source: Lowry 2001b, pp. 158-159; DTN\#MO0106EBSCT3AP.004. 
Table 7. Cation Analysis of Column Fluid

\begin{tabular}{|c|c|c|c|c|c|c|c|c|c|c|c|}
\hline \multirow[b]{2}{*}{$\begin{array}{c}\text { Sample } \\
\text { Description }\end{array}$} & \multirow[b]{2}{*}{$\begin{array}{l}\text { Sample } \\
\text { Date }\end{array}$} & \multirow[b]{2}{*}{$\begin{array}{l}\text { Sample } \\
\text { Time }\end{array}$} & \multirow[b]{2}{*}{ SMA ID } & \multicolumn{8}{|c|}{ Cation Analysis Results (mg/L) Column Fluid Basis } \\
\hline & & & & $\frac{E}{\frac{E}{D}}$ & $\begin{array}{l}\text { 을 } \\
\frac{\bar{B}}{5}\end{array}$ & 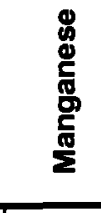 & $\underline{\text { 은 }}$ & 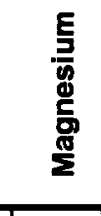 & $\begin{array}{l}\text { E } \\
\\
8 \\
8\end{array}$ & $\frac{E}{\frac{E}{3}}$ & 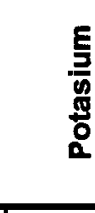 \\
\hline $\begin{array}{l}\text { Const. Head Supply, } \\
\text { Cation Aliquot }\end{array}$ & $12 / 23 / 99$ & N/A & $\begin{array}{l}\text { SPCO05 } \\
29269\end{array}$ & 2.47 & $<0.51$ & $<0.01$ & $<0.2$ & 0.77 & 0.6 & $<0.01$ & $<0.51$ \\
\hline $\begin{array}{l}\text { Const. Head Supply, } \\
\text { Cation Aliquot }\end{array}$ & $1 / 7 / 00$ & N/A & $\begin{array}{l}\text { SPC005 } \\
29277\end{array}$ & $<0.51$ & $<0.51$ & $<0.01$ & $<0.2$ & $<0.51$ & $<0.51$ & $<0.01$ & $<0.51$ \\
\hline $\begin{array}{l}\text { CT3, Port\#1, Cation } \\
\text { Aliquot }\end{array}$ & $9 / 18 / 00$ & $8: 36: 00$ PM & $\begin{array}{l}\text { SPCO05 } \\
60873\end{array}$ & 5.27 & 86.37 & $<0.08$ & $<0.81$ & $<0.81$ & 53.83 & 1.85 & 3.25 \\
\hline $\begin{array}{l}\text { CT3, Port\#1, Cation } \\
\text { Aliquot }\end{array}$ & $9 / 19 / 00$ & 3:20:00 PM & \begin{tabular}{|l|}
$\mathrm{SPC} 005$ \\
60876
\end{tabular} & 51.22 & 279.77 & 0.13 & 0.10 & 5.97 & 217.75 & 4.99 & 14.35 \\
\hline $\begin{array}{l}\text { CT3, Port\#1, Cation } \\
\text { Aliquot }\end{array}$ & $9 / 25 / 00$ & 3:40:00 PM & \begin{tabular}{|l|}
$\mathrm{SPC} 005$ \\
60878
\end{tabular} & 21.87 & 286.06 & $<4.31$ & $<0.86$ & $<0.86$ & 329.60 & 5.98 & 14.41 \\
\hline $\begin{array}{l}\text { CT3, Port\#1, Cation } \\
\text { Aliquot }\end{array}$ & $10 / 2 / 00$ & 1:25:00 PM & \begin{tabular}{|l|}
$\mathrm{SPC} 005$ \\
60882 \\
\end{tabular} & 1.57 & 228.50 & $<4.29$ & $<0.86$ & $<0.86$ & 190.77 & 0.99 & 4.14 \\
\hline $\begin{array}{l}\text { CT3, Port\#1, Cation } \\
\text { Aliquot }\end{array}$ & $10 / 5 / 00$ & 5:45:00 PM & \begin{tabular}{|l|}
$\mathrm{SPC} 005$ \\
60885
\end{tabular} & 25.66 & 349.91 & $<4.32$ & $<0.86$ & $<0.86$ & 282.19 & 13.32 & 14.54 \\
\hline $\begin{array}{l}\text { CT3, Port\#1, Cation } \\
\text { Aliquot }\end{array}$ & $10 / 6 / 00$ & 10:00:00 AM & \begin{tabular}{|l|} 
SPC005 \\
60890
\end{tabular} & 1.26 & 361.63 & $<4.33$ & $<0.87$ & $<0.87$ & 229.68 & 0.98 & 10.09 \\
\hline $\begin{array}{l}\text { CT3, Port\#1, Cation } \\
\text { Aliquot }\end{array}$ & $10 / 11 / 00$ & 2:30:00 PM & $\begin{array}{l}\text { SPC005 } \\
60898 \\
\end{array}$ & 15.48 & 293.98 & $<0.82$ & $<0.82$ & 0.18 & 203.75 & 20.86 & 18.73 \\
\hline $\begin{array}{l}\text { CT3, Port\#1, Cation } \\
\text { Aliquot }\end{array}$ & $10 / 18 / 00$ & 3:09:00 PM & \begin{tabular}{|l|}
$\mathrm{SPC} C 05$ \\
42887 \\
\end{tabular} & 1.62 & 174.53 & $<0.82$ & $<0.82$ & 0.29 & 67.45 & 2.17 & 4.69 \\
\hline $\begin{array}{l}\text { CT3, Port\#1, Cation } \\
\text { Aliquot }\end{array}$ & $10 / 25 / 00$ & 12:48:00 PM & $\begin{array}{l}\text { SPC005 } \\
60872 \\
\end{array}$ & 16.32 & 627.69 & $<0.82$ & $<0.82$ & 0.13 & 149.75 & 23.22 & 16.11 \\
\hline $\begin{array}{l}\text { CT3, Port\#1, Cation } \\
\text { Aliquot }\end{array}$ & $11 / 1 / 00$ & 2:50:00 PM & \begin{tabular}{|l|}
$\mathrm{SPC} 005$ \\
60869
\end{tabular} & 48.39 & 723.78 & $<0.83$ & $<0.83$ & 0.24 & 185.02 & 53.15 & 21.47 \\
\hline $\begin{array}{l}\text { CT3, Port\#1, Cation } \\
\text { Aliquot }\end{array}$ & $11 / 8 / 00$ & 1:00:00 PM & \begin{tabular}{|l|}
$\mathrm{SPC} C 05$ \\
60894
\end{tabular} & 59.05 & N/A & $<0.82$ & $<0.82$ & 0.29 & 235.83 & 97.87 & 32.74 \\
\hline
\end{tabular}

N/A: Not Analyzed 
Table 7. Cation Analysis of Column Fluid (Continued)

\begin{tabular}{|c|c|c|c|c|c|c|c|c|c|c|c|}
\hline \multirow[b]{2}{*}{$\begin{array}{c}\text { Sample } \\
\text { Description }\end{array}$} & \multirow[b]{2}{*}{$\begin{array}{c}\text { Sample } \\
\text { Date }\end{array}$} & \multirow[b]{2}{*}{$\begin{array}{c}\text { Sample } \\
\text { Time }\end{array}$} & \multirow[b]{2}{*}{ SMA ID } & \multicolumn{8}{|c|}{ Cation Analysis Results (mg/L) Column Fluid Basis } \\
\hline & & & & $\frac{\underline{\xi}}{\frac{5}{0}}$ & 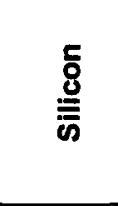 & 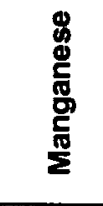 & 은 & 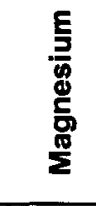 & $\begin{array}{l}\text { E } \\
\text { 韋 } \\
\text { 员 }\end{array}$ & $\begin{array}{l}\frac{E}{E} \\
\frac{E}{E} \\
\frac{E}{\alpha}\end{array}$ & 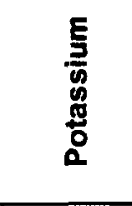 \\
\hline $\begin{array}{l}\text { CT3, Port\#1, Cation } \\
\text { Aliquot }\end{array}$ & $11 / 15 / 00$ & 2:07:00 PM & $\begin{array}{l}\text { SPC005 } \\
42890\end{array}$ & 21.63 & 315.90 & $<0.82$ & $<0.82$ & 0.18 & 174.52 & 23.75 & 10.89 \\
\hline $\begin{array}{l}\text { CT3, Port\#1, Cation } \\
\text { Aliquot }\end{array}$ & $11 / 20 / 00$ & 9:25:00 AM & $\begin{array}{l}\text { SPC005 } \\
42894\end{array}$ & 4.34 & 354.19 & $<0.82$ & $<0.82$ & $<0.08$ & 301.62 & 5.86 & 4.82 \\
\hline $\begin{array}{l}\text { CT3, Port\#1, Cation } \\
\text { Aliquot }\end{array}$ & $11 / 21 / 00$ & 2:30:00 PM & $\begin{array}{l}\text { SPC005 } \\
60857\end{array}$ & 2.79 & 165.54 & $<0.83$ & $<0.83$ & 0.08 & 131.77 & 4.14 & 7.01 \\
\hline $\begin{array}{l}\text { CT3, Por\#\#1, Cation } \\
\text { Aliquot }\end{array}$ & $12 / 6 / 00$ & 12:30:00 PM & $\begin{array}{l}\text { SPC005 } \\
42897\end{array}$ & 5.42 & 447.31 & $<0.83$ & $<0.83$ & $<0.08$ & 409.13 & 5.34 & 17.24 \\
\hline $\begin{array}{l}\text { CT3, Port\#1, Cation } \\
\text { Aliquot }\end{array}$ & $12 / 18 / 00$ & 9:20:00 AM & $\begin{array}{l}\text { SPC005 } \\
60865\end{array}$ & 7.80 & 373.22 & $<0.08$ & $<0.41$ & $\mid<0.41$ & 235.12 & 14.67 & 12.96 \\
\hline $\begin{array}{l}\text { CT3, Port\#1, Cation } \\
\text { Aliquot }\end{array}$ & $12 / 19 / 00$ & 9:35:00 AM & $\begin{array}{l}\text { SPC005 } \\
60861\end{array}$ & 2.27 & 322.06 & $<0.08$ & $<0.41$ & $<0.41$ & 238.73 & 3.83 & 6.82 \\
\hline $\begin{array}{l}\text { CT3, Port\#1, Cation } \\
\text { Aliquot }\end{array}$ & 1/4/01 & 1:15:00 PM & $\begin{array}{l}\text { SPC005 } \\
73001\end{array}$ & $<0.82$ & 200.89 & $<0.08$ & $<0.41$ & 0.43 & 120.53 & 0.82 & 6.37 \\
\hline $\begin{array}{l}\text { CT3, Port\#1, Cation } \\
\text { Aliquot }\end{array}$ & $1 / 8 / 01$ & 8:30:00 AM & $\begin{array}{l}\text { SPC005 } \\
73004\end{array}$ & $<0.83$ & 111.89 & $<0.08$ & $<0.41$ & $<0.41$ & 50.89 & 1.09 & N/A \\
\hline $\begin{array}{l}\text { CT3, Port\#1, Cation } \\
\text { Aliquot }\end{array}$ & 1/16/01 & 8:47:00 AM & $\begin{array}{l}\text { SPC005 } \\
73007\end{array}$ & 2.21 & 171.91 & $<0.08$ & $<0.41$ & $<0.41$ & 150.41 & 5.56 & 0.02 \\
\hline $\begin{array}{l}\text { CT3, Port\#1, Cation } \\
\text { Dup. }\end{array}$ & $1 / 16 / 01$ & 8:47:00 AM & $\begin{array}{l}\text { SPCO05 } \\
73010\end{array}$ & 2.45 & 200.17 & $<0.08$ & $<0.41$ & $<0.41$ & 153.18 & 5.50 & 1.96 \\
\hline
\end{tabular}

N/A: Not Analyzed

Source: LOWTy 2001c, p. 61; DTN\#LA0106ZW831234.002; DTN\#LA0106ZW831234.003; DTN\#MO0104EBSCTEGC.000. 


\begin{tabular}{|c|c|c|c|c|c|c|c|c|c|c|}
\hline \multirow[b]{2}{*}{$\begin{array}{c}\text { Sample } \\
\text { Description }\end{array}$} & \multirow[b]{2}{*}{$\begin{array}{c}\text { Sample } \\
\text { Date }\end{array}$} & \multirow[b]{2}{*}{$\begin{array}{c}\text { Sample } \\
\text { Time }\end{array}$} & \multirow[b]{2}{*}{ SMA ID } & \multicolumn{7}{|c|}{ Anion Analysis Results (mg/L) Column Fluid Basis } \\
\hline & & & & $\begin{array}{l}\text { 은 } \\
\text { 흔 }\end{array}$ & $\frac{\frac{\pi}{0}}{\frac{0}{5}}$ & 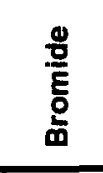 & 荳 & 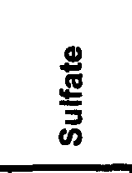 & $\begin{array}{l}\frac{g}{0} \\
\frac{2}{8} \\
\frac{8}{0} \\
\frac{c}{0}\end{array}$ & 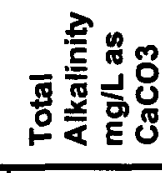 \\
\hline $\begin{array}{l}\text { Const. Head Supply, Anion } \\
\text { Aliquot }\end{array}$ & $12 / 23 / 99$ & N/A & $\begin{array}{l}\text { SPC005 } \\
29268\end{array}$ & $<0.1$ & $<0.1$ & $<0.06$ & $<0.06$ & 1.20 & N/A & $\mathrm{N} / \mathrm{A}$ \\
\hline $\begin{array}{l}\text { Const. Head Supply, Anion } \\
\text { Aliquot }\end{array}$ & $1 / 7 / 00$ & N/A & $\begin{array}{l}\text { SPC005 } \\
29276\end{array}$ & $<0.1$ & $<0.1$ & $<0.06$ & $<0.06$ & 0.50 & N/A & $\mathrm{N} / \mathrm{A}$ \\
\hline $\begin{array}{l}\text { CT3, Port\#1, Anion/Alkalinity } \\
\text { Aliquot }\end{array}$ & $9 / 18 / 00$ & 8:36:00 PM & $\begin{array}{l}\text { SPC005 } \\
60874\end{array}$ & 2.14 & $\begin{array}{l}26.959 \\
3\end{array}$ & 4.3514 & 3.2292 & 44.2281 & 0.0922 & 16 \\
\hline $\begin{array}{l}\text { CT3, Port\#1, Anion/Alkalinity } \\
\text { Aliquot }\end{array}$ & 9/19/00 & 3:20:00 PM & $\begin{array}{l}\text { SPC005 } \\
60875\end{array}$ & 11.7 & $\begin{array}{l}115.06 \\
3\end{array}$ & $\begin{array}{l}25.816 \\
6\end{array}$ & 17.0944 & 284.490 & 0.0356 & N/A \\
\hline $\begin{array}{l}\text { CT3, Port\#1, Anion/Alkalinity } \\
\text { Aliquot }\end{array}$ & 9/25/00 & 3:40:00 PM & $\begin{array}{l}\text { SPC005 } \\
60877\end{array}$ & 25.8541 & 123.01 & 27.1 & 14.3573 & $\begin{array}{l}293.844 \\
9\end{array}$ & $<0.2$ & N/A \\
\hline $\begin{array}{l}\text { CT3, Port\#1, Anion/Alkalinity } \\
\text { Aliquot }\end{array}$ & $10 / 2 / 00$ & 1:25:00 PM & $\begin{array}{l}\text { SPC005 } \\
60881\end{array}$ & 13.3746 & 44.06 & 10.76 & $<0.18$ & 99.5256 & 0.2108 & 87 \\
\hline $\begin{array}{l}\text { CT3, Port\#1, Anion/Alkalinity } \\
\text { Aliquot }\end{array}$ & $10 / 5 / 00$ & 5:45:00 PM & $\begin{array}{l}\text { SPCO05 } \\
60884\end{array}$ & 23.8375 & 106.14 & 22 & 10.1832 & $\begin{array}{l}244.568 \\
9\end{array}$ & $<0.2$ & 79 \\
\hline $\begin{array}{l}\text { CT3, Port\#1, Anion/Alkalinity } \\
\text { Aliquot }\end{array}$ & $10 / 6 / 00$ & 10:00:00 AM & $\begin{array}{l}\text { SPC005 } \\
60889\end{array}$ & 16.542 & 65.66 & 13.61 & 6.0989 & $\begin{array}{l}148.718 \\
6\end{array}$ & $<0.2$ & 86 \\
\hline $\begin{array}{l}\text { CT3, Port\#1, Anion/Alkalinity } \\
\text { Aliquot }\end{array}$ & $10 / 11 / 00$ & 2:30:00 PM & $\begin{array}{l}\text { SPC005 } \\
60897\end{array}$ & 17.5153 & 47.12 & 8.97 & 3.9711 & $\begin{array}{l}93.6964 \\
5\end{array}$ & $<0.2$ & 199 \\
\hline $\begin{array}{l}\text { CT3, Port\#1, Anion/Alkalinity } \\
\text { Aliquot }\end{array}$ & $10 / 18 / 00$ & 3:09:00 PM & $\begin{array}{l}\text { SPCO05 } \\
42886\end{array}$ & 5.3412 & 20.59 & 1.15 & 0.7868 & 12.4775 & 0.2616 & 76 \\
\hline $\begin{array}{l}\text { CT3, Port\#1, Anion/Alkalinity } \\
\text { Aliquot }\end{array}$ & $10 / 25 / 00$ & 12:48:00 PM & $\begin{array}{l}\text { SPC005 } \\
60871 \\
\end{array}$ & N/A & N/A & N/A & N/A & $\mathrm{N} / \mathrm{A}$ & N/A & 160 \\
\hline $\begin{array}{l}\text { CT3, Port\#1, Anion/Alkalinity } \\
\text { Aliquot }\end{array}$ & $11 / 1 / 00$ & 2:50:00 PM & $\begin{array}{l}\text { SPCO05 } \\
60868\end{array}$ & N/A & N/A & N/A & N/A & $\mathrm{N} / \mathrm{A}$ & N/A & 253 \\
\hline
\end{tabular}

N/A: Not Analyzed 
Table 8. Anion Analysis of Column Fluid (Continued)

\begin{tabular}{|c|c|c|c|c|c|c|c|c|c|c|}
\hline \multirow[b]{2}{*}{$\begin{array}{l}\text { Sample } \\
\text { Description }\end{array}$} & \multirow[b]{2}{*}{$\begin{array}{c}\text { Sample } \\
\text { Date }\end{array}$} & \multirow[b]{2}{*}{$\begin{array}{c}\text { Sample } \\
\text { Time }\end{array}$} & \multirow[b]{2}{*}{ SMA ID } & \multicolumn{7}{|c|}{ Anion Analysis Results (mg/L) Column Fluid Basis } \\
\hline & & & & $\begin{array}{l}\text { 은 } \\
\frac{0}{0}\end{array}$ & $\frac{\frac{0}{0}}{\frac{0}{0}}$ & 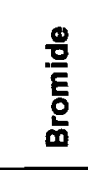 & 畩 & 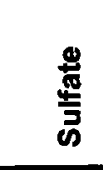 & $\begin{array}{l}\frac{8}{\pi} \\
\frac{0}{8} \\
\frac{0}{0} \\
\frac{0}{2}\end{array}$ & 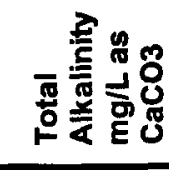 \\
\hline $\begin{array}{l}\text { CT3, Port\#1, Anion/Alkalinity } \\
\text { Aliquot }\end{array}$ & $11 / 8 / 00$ & 1:00:00 PM & $\begin{array}{l}\text { SPC005 } \\
60893\end{array}$ & 6.39 & 50.42 & 1.85 & 0.71 & 22.44 & 1.28 & 304 \\
\hline $\begin{array}{l}\text { CT3, Port\#1, Anion/Alkalinity } \\
\text { Aliquot }\end{array}$ & $11 / 15 / 00$ & 2:07:00 PM & $\begin{array}{l}\text { SPC005 } \\
42889\end{array}$ & 4.61 & 33.31 & 1.15 & 0.75 & 12.93 & 0.95 & 251 \\
\hline $\begin{array}{l}\text { CT3, Port\#1, Anion/Alkalinity } \\
\text { Aliquot }\end{array}$ & $11 / 20 / 00$ & 9:25:00 AM & $\begin{array}{l}\text { SPC005 } \\
42892\end{array}$ & 5.41 & 30.92 & 1.13 & 0.31 & 12.26 & 0.77 & 274 \\
\hline $\begin{array}{l}\text { CT3, Port\#1, Anion/Alkalinity } \\
\text { Aliquot }\end{array}$ & $11 / 21 / 00$ & 2:30:00 PM & \begin{tabular}{|l|} 
SPC005 \\
60855
\end{tabular} & 4.46 & 50.65 & 1.9 & 2.25 & 26.12 & 0.35 & 163 \\
\hline $\begin{array}{l}\text { CT3, Port\#1, Anion/Alkalinity } \\
\text { Aliquot }\end{array}$ & $12 / 6 / 00$ & 12:30:00 PM & $\begin{array}{l}\text { SPC005 } \\
42896\end{array}$ & 9.65 & 89.82 & 3.35 & 2.57 & 47.18 & 1.18 & 646 \\
\hline $\begin{array}{l}\text { CT3, Port\#1, Anion/Alkalinity } \\
\text { Aliquot }\end{array}$ & $12 / 18 / 00$ & 9:20:00 AM & \begin{tabular}{|l|} 
SPC005 \\
60863
\end{tabular} & 6.76 & 46.68 & 1.79 & 5.07 & 16.84 & 0.91 & 391 \\
\hline $\begin{array}{l}\text { CT3, Port\#1, Anion/Alkalinity } \\
\text { Aliquot }\end{array}$ & $12 / 19 / 00$ & 9:35:00 AM & $\begin{array}{l}\text { SPC005 } \\
60860\end{array}$ & 5.41 & 39.03 & 1.21 & 3.4 & 13.65 & 0.94 & 403 \\
\hline $\begin{array}{l}\text { CT3, Port\#1, Anion/Alkalinity } \\
\text { Aliquot }\end{array}$ & $1 / 4 / 01$ & 1:15:00 PM & $\begin{array}{l}\text { SPCO05 } \\
73000\end{array}$ & 6.25 & 26.03 & 0.62 & 2.27 & 6.09 & 0.87 & 185 \\
\hline $\begin{array}{l}\text { CT3, Port\#1, Anion/Alkalinity } \\
\text { Aliquot }\end{array}$ & $1 / 8 / 01$ & 8:30:00 AM & $\begin{array}{l}\text { SPCO05 } \\
73003\end{array}$ & 3.83 & 16.81 & 0.4 & 1.2 & 3.67 & 0.19 & 80 \\
\hline $\begin{array}{l}\text { CT3, Port\#1, Anion/Alkalinity } \\
\text { Aliquot }\end{array}$ & $1 / 16 / 01$ & 8:47:00 AM & $\begin{array}{l}\text { SPC005 } \\
73008\end{array}$ & N/A & N/A & N/A & N/A & N/A & N/A & 261 \\
\hline $\begin{array}{l}\text { CT3, Port\#1, Anion/Alkalinity } \\
\text { Dup. }\end{array}$ & $1 / 16 / 01$ & $8: 47: 00 \mathrm{AM}$ & $\begin{array}{l}\text { SPC005 } \\
73009\end{array}$ & N/A & N/A & N/A & N/A & N/A & $\mathrm{N} / \mathrm{A}$ & 264 \\
\hline
\end{tabular}

N/A: Not Analyzed

Source: DTN\#LA0106ZW831234.001; ; DTN\#LA0106ZW831234.004; DTN\#LA0106ZW831234.005; DTN\#LA0106ZW831234.006; DTN\#LA0106ZW831234.007; DTN\#LA0106ZW831234.008; DTN\#LA0106ZW831234.009; DTN\#MO0104EBSCTEGC.000; Lowry 2001 c, p. 61. 
Table 9. pH Measurement Results from Column Test No. 3 Taken at Room Temperature

\begin{tabular}{|c|c|c|c|c|c|}
\hline $\begin{array}{l}\text { Data } \\
\text { Time }\end{array}$ & SEA Sample ID & $\begin{array}{c}\mathbf{p H} \\
\text { Measurement } \\
\text { Result }\end{array}$ & $\begin{array}{c}\text { Measurement } \\
\text { Temperature } \\
{ }^{\circ} \mathrm{C} \\
\end{array}$ & $\begin{array}{c}\text { Column } \\
\text { Temperature }{ }^{\circ} \mathrm{C} \\
\text { I Time Temp. } \\
\text { Recorded }\end{array}$ & Sample Description \\
\hline 9/18/00 20:36 & CT3-pH-091800-001 & 8.70 & 25.0 & $89.9642 / 20: 37$ & $\begin{array}{l}\text { Syringe Sample, Port } \\
\# 1\end{array}$ \\
\hline 9/18/00 20:36 & CT3-pH-091800-002 & 7.99 & 24.5 & N/A & $\begin{array}{l}\text { Syringe Sample, } \\
\text { Column Supply Water }\end{array}$ \\
\hline 9/19/00 15:20 & СТ3-pH-091900-001 & 6.58 & 27.0 & $93.1159 / 15: 22$ & $\begin{array}{l}\text { Syringe Sample, Port } \\
\# 1\end{array}$ \\
\hline 9/19/00 15:20 & СТ3-pH-091900-002 & 7.36 & 26.4 & N/A & $\begin{array}{l}\text { Syringe Sample, } \\
\text { Column Supply Water }\end{array}$ \\
\hline $9 / 25 / 0015: 40$ & CT3-pH-092500-001 & 9.04 & 23.8 & $91.8 / 16: 02$ & $\begin{array}{l}\text { Syringe Sample, Port } \\
\# 1\end{array}$ \\
\hline $10 / 2 / 0013: 25$ & CT3-pH-100200-001 & 9.37 & 25.2 & $23.2471 / 13: 02$ & $\begin{array}{l}\text { Syringe Sample, Port } \\
\# 1 \text {; Column at room } \\
\text { temperature after } \\
\text { heater fail }\end{array}$ \\
\hline $10 / 5 / 0017: 45$ & CT3-pH-100500-001 & 7.96 & 24.7 & $93.8267 / 17: 47$ & $\begin{array}{l}\text { Syringe Sample, Port } \\
\# 1 \text {; Sample four } \\
\text { hours after restart }\end{array}$ \\
\hline $10 / 6 / 0010: 00$ & CT3-pH-100600-001 & 8.86 & 23.9 & $94.4501 / 10: 02$ & $\begin{array}{l}\text { Syringe Sample, Port } \\
\# 1\end{array}$ \\
\hline $10 / 6 / 0012: 30$ & CT3-pH-100600-002 & 9.08 & 25.1 & $93.8969 / 12: 32$ & $\begin{array}{l}\text { Syringe Sample, Port } \\
\# 1\end{array}$ \\
\hline 10/11/00 14:30 & СТ3-pH-101100-001 & 9.71 & 21.6 & $93.0266 / 14: 02$ & $\begin{array}{l}\text { Syringe Sample, Port } \\
\# 1\end{array}$ \\
\hline 10/18/00 15:09 & CT3-pH-101800-001 & 9.41 & 21.7 & $94.132 / 15: 02$ & $\begin{array}{l}\text { Syringe Sample, Port } \\
\# 1\end{array}$ \\
\hline $10 / 25 / 0012: 48$ & CT3-pH-102500-001 & 9.75 & 22.6 & $94.7533 / 13: 02$ & $\begin{array}{l}\text { Syringe Sample, Port } \\
\# 1\end{array}$ \\
\hline $11 / 1 / 0014: 50$ & CT3-pH-110100-001 & 9.96 & 19.1 & $94.4308 / 15: 02$ & $\begin{array}{l}\text { Syringe Sample, Port } \\
\# 1\end{array}$ \\
\hline $11 / 15 / 0014: 07$ & CT3-pH-111500-001 & 9.98 & 21.1 & $93.9801 / 14: 02$ & $\begin{array}{l}\text { Syringe Sample, Port } \\
\# 1\end{array}$ \\
\hline $11 / 21 / 0014: 30$ & СТ3-pH-112100-001 & 9.88 & 22.6 & 93.0512 / 14:32 & $\begin{array}{l}\text { Syringe Sample, Port } \\
\# 1 ; 6.5 \text { hours after } \\
\text { power restart } \\
\end{array}$ \\
\hline 1/4/01 13:15 & СT3-pH-010401-001 & 9.89 & 23.5 & $93.7646 / 13: 17$ & $\begin{array}{l}\text { Syringe Sample, Port } \\
\# 1 \text {; Baseline data } \\
\text { before cooling cap } \\
\text { temp test }\end{array}$ \\
\hline 1/8/01 8:30 & СТ3-pH-010801-001 & 9.60 & 21.9 & 92.1022 / 8:02 & $\begin{array}{l}\text { Syringe Sample, Port } \\
\# 1\end{array}$ \\
\hline
\end{tabular}

Note: Column temperatures/times were obtained from RTD02 except for the column temperature/time for CT3-pH-092500-001, which was obtained from RTD04.

Source: DTN\#MO0106EBSCT3PH.005 for pH measurement data; DTN\#MO0107EBSTHCT3.007 for column temps/times. 
Table 10. pH Measurement Results from Column Test No. 3 (To be Used Non-Q Data Only Because Measured Values Fell Above Calibration Curve of Instrument)

\begin{tabular}{|c|c|c|c|c|c|}
\hline $\begin{array}{l}\text { Data } \\
\text { Time }\end{array}$ & SEA Sample ID & \begin{tabular}{|c|} 
pH \\
$\begin{array}{c}\text { Measurement } \\
\text { Result }\end{array}$
\end{tabular} & $\begin{array}{c}\text { Measurement } \\
\text { Temperature } \\
{ }^{\circ} \mathrm{C}\end{array}$ & $\begin{array}{c}\text { Column } \\
\text { Temperature }{ }^{\circ} \mathrm{C} \text { / } \\
\text { Time Temp. } \\
\text { Recorded }\end{array}$ & Sample Description \\
\hline $11 / 8 / 0013: 00$ & СТ3-pH-110800-001 & 10.08 & 21.4 & $94.8129 / 13: 02$ & Syringe Sample, Port \# 1 \\
\hline $11 / 20 / 009: 25$ & CT3-pH-112000-001 & 10.23 & 21.7 & $22.6224 / 9: 27$ & $\begin{array}{l}\text { Syringe Sample, Port \# 1; } \\
\text { Following controlled power } \\
\text { shutdown }\end{array}$ \\
\hline $12 / 6 / 0012: 30$ & CT3-pH-120600-001 & 10.35 & 22.5 & $93.8947 / 12: 02$ & Syringe Sample, Port \# 1 \\
\hline 12/18/00 9:20 & CT3-pH-121800-001 & 10.25 & 22.4 & $94.7108 / 9: 02$ & $\begin{array}{l}\text { Syringe Sample, Port \# 1; } \\
\text { Air flow test? }\end{array}$ \\
\hline 12/19/00 9:35 & CT3-pH-121900-001 & 10.26 & 22.0 & $92.4837 / 9: 37$ & Syringe Sample, Port \# 1 \\
\hline
\end{tabular}

Note: Column temperatures/times were obtained from RTD02.

Source: DTN\#MO0106EBSCT3PH.006 (for pH measurement data), DTN\#MO0107EBSTHCT3.007 (for column temps/times) 
Table 11. Quantitative XRD Mineralogy of EBS Thermal/Hydraulic/Chemical Column Test No. 3 Samples (Weight Percent)

\begin{tabular}{|c|c|c|c|c|c|c|c|c|c|c|}
\hline Sample Identifier & Smectite & Mica & Tridymite & Cristobalite & Quartz & Feldspar & Hematite & Amorphous" & Opal-CT & Total \\
\hline \multicolumn{11}{|l|}{$\begin{array}{c}\text { Pre-test crushed } \\
\text { tuff }\end{array}$} \\
\hline LANL 3633p1 & $2 \pm 1$ & trace & $4 \pm 1$ & $28 \pm 2$ & $8 \pm 1$ & $54 \pm 8$ & $1 \pm 1$ & - & - & $97 \pm 8$ \\
\hline LANL 3633p2 & $2 \pm 1$ & trace & $5 \pm 1$ & $28 \pm 2$ & $7 \pm 1$ & $53 \pm 7$ & $1 \pm 1$ & - & - & $96 \pm 8$ \\
\hline LANL 3633p3 & $3 \pm 1$ & trace & $4 \pm 1$ & $26 \pm 2$ & $7 \pm 1$ & $54 \pm 8$ & $1 \pm 1$ & $\overline{-}$ & - & $95 \pm 8$ \\
\hline LANL 3633p4 & $2 \pm 1$ & trace & $4 \pm 1$ & $29 \pm 2$ & $8 \pm 1$ & $55 \pm 8$ & $1 \pm 1$ & $=$ & - & $99 \pm 8$ \\
\hline LANL 3633p5 & $3 \pm 1$ & trace & $4 \pm 1$ & $28 \pm 2$ & $8 \pm 1$ & $56 \pm 8$ & $1 \pm 1$ & $=$ & - & $100 \pm 8$ \\
\hline \multicolumn{11}{|l|}{ Post-test, lift 10} \\
\hline LANL 3628p1 & $2 \pm 1$ & trace & $5 \pm 1$ & $27 \pm 2$ & $7 \pm 1$ & $55 \pm 8$ & $1 \pm 1$ & - & - & $97 \pm 8$ \\
\hline LANL 3628p2 & $2 \pm 1$ & trace & $5 \pm 1$ & $27 \pm 2$ & $8 \pm 1$ & $55 \pm 8$ & $1 \pm 1$ & $=$ & $\overline{-}$ & $98 \pm 8$ \\
\hline LANL 3628p3 & $3 \pm 1$ & trace & $4 \pm 1$ & $28 \pm 2$ & $9 \pm 1$ & $56 \pm 8$ & $1 \pm 1$ & $=$ & - & $101 \pm 8$ \\
\hline LANL 3628p4 & $3 \pm 1$ & trace & $4 \pm 1$ & $28 \pm 2$ & $8 \pm 1$ & $54 \pm 8$ & $1 \pm 1$ & $\overline{-}$ & - & $98 \pm 8$ \\
\hline LANL 3628p5 & $4 \pm 1$ & trace & $5 \pm 1$ & $27 \pm 2$ & $7 \pm 1$ & $55 \pm 8$ & $1 \pm 1$ & - & $=$ & $99 \pm 8$ \\
\hline \multicolumn{11}{|l|}{ Post-test, cement } \\
\hline LANL 3626p1 & - & - & 二 & - & trace & $3 \pm 1$ & $=$ & $92 \pm 1$ & $5 \pm 1$ & $100 \pm 1$ \\
\hline LANL 3627p1 & $\overline{-}$ & $=$ & - & - & trace & $2 \pm 1$ & $=$ & $96 \pm 1$ & $2 \pm 1$ & $100 \pm 1$ \\
\hline
\end{tabular}

Source: LA0110SL831225.001 and Lowry 2001c, p. 70

Notes:

Errors are conservative estimated 2-sigma values for error of analysis.

trace" signifies a phase present at a level below 0.5 weight\%.

- signifies that a phase was not detected.

"Identified on the basis of $\mathrm{x}$-ray diffraction and energy-dispersive $\mathrm{x}$-ray spectroscopy as opal-A. 
Table 12. Tuff Loading for Column Test No. 3

\begin{tabular}{|c|c|c|c|c|c|c|c|c|c|c|}
\hline Lift No. & $\begin{array}{l}\text { Distance to } \\
\text { Top of Lift } \\
(\mathrm{cm})\end{array}$ & Height $(\mathrm{cm})$ & $\begin{array}{l}\text { Lift Volume } \\
\quad\left(\mathrm{cm}^{3}\right)\end{array}$ & $\begin{array}{l}\text { Actual Mass } \\
\text { Loaded (Kg) }\end{array}$ & $\begin{array}{c}\text { Loading } \\
\text { Balance } \\
\text { Uncertainty } \\
\text { (Kg) }\end{array}$ & $\begin{array}{c}\text { Calculated } \\
\text { Bulk Density } \\
\left(\mathrm{g} / \mathrm{cm}^{3}\right)\end{array}$ & $\begin{array}{c}\text { Post } \\
\text { Experiment } \\
\text { Mass }(\mathrm{Kg})\end{array}$ & $\begin{array}{c}\text { Unloading } \\
\text { Balance } \\
\text { Uncertainty } \\
\text { (kg) }\end{array}$ & $\begin{array}{l}\text { Net Change } \\
\text { in Mass (Kg) }\end{array}$ & $\begin{array}{c}\text { Percent } \\
\text { Difference }\end{array}$ \\
\hline 1 & 86.7 & 7.1 & 1199 & 1.6321 & $+/-0.0005$ & 1.361 & 1.73208 & $+1-0.00006$ & 0.1000 & $5.944 \%$ \\
\hline 2 & 77.4 & 9.3 & 1575 & 1.9986 & $+1-0.0005$ & 1.269 & 1.98596 & $+1-0.00006$ & -0.0126 & $-0.634 \%$ \\
\hline 3 & 68.5 & 8.9 & 1508 & 1.9240 & $+1-0.0005$ & 1.276 & 1.9123 & $+/-0.00006$ & -0.0117 & $-0.610 \%$ \\
\hline 4 & 60 & 8.5 & 1440 & 1.8107 & $+/-0.0005$ & 1.258 & 1.80045 & $+1-0.00006$ & -0.0102 & $-0.568 \%$ \\
\hline 5 & 50.7 & 9.3 & 1575 & 1.9504 & $+/-0.0005$ & 1.238 & 1.93958 & $+1-0.00006$ & -0.0108 & $-0.556 \%$ \\
\hline 6 & 41.7 & 9.0 & 1525 & 1.8830 & $+1-0.0005$ & 1.235 & 1.87167 & $+1-0.00006$ & -0.0113 & $-0.604 \%$ \\
\hline 7 & 32.6 & 9.1 & 1542 & 1.8965 & $+/ .0 .0005$ & 1.230 & 1.88481 & $+/-0.00006$ & -0.0117 & $-0.618 \%$ \\
\hline 8 & 23.5 & 9.1 & 1542 & 1.9351 & $+1-0.0005$ & 1.255 & 1.92599 & $+1-0.00006$ & -0.0091 & $-0.472 \%$ \\
\hline 9 & 14.5 & 9.0 & 1525 & 1.8784 & $+/-0.0005$ & 1.232 & 1.8585 & $+/-0.00006$ & -0.0199 & $-1.065 \%$ \\
\hline 10 & 6.6 & 7.9 & 1338 & 1.6312 & $+/-0.0005$ & 1.219 & 1.6016 & $+1-0.00006$ & -0.0296 & $-1.831 \%$ \\
\hline \multicolumn{3}{|c|}{ Totals (Lifts 1-10) } & 14768.3 & 18.54 & & - & \multirow[t]{3}{*}{18.513} & \multirow[b]{4}{*}{$\begin{array}{c}\text { SUM of } \\
\text { Differences } \\
\text { Total } \\
\text { Percent } \\
\text { Difference }\end{array}$} & \multirow[b]{4}{*}{$\begin{array}{l}-0.0271 \\
-0.146 \%\end{array}$} & \\
\hline Aver & ad Values (Lift & s-10) & 1508 & 1.879 & & 1.246 & & & & \\
\hline \multicolumn{3}{|c|}{ Standard Deviation (Lifts 2-10) } & 75 & 0.107 & & 0.019 & & & & \\
\hline & & & & & & & & & & \\
\hline \multirow{2}{*}{\multicolumn{3}{|c|}{ Balance Specifications }} & & & & & & & & \\
\hline & & & Capacity & Readability & Uncertainty & & & & & \\
\hline \multicolumn{2}{|c|}{ Loading Balance : } & $\begin{array}{l}\text { Mettler } \\
\text { PM16-k }\end{array}$ & $16 \mathrm{~kg}$ & $0.1 \mathrm{~g}$ & $+1-0.5 \mathrm{~g}$ & & & & & \\
\hline \multicolumn{2}{|c|}{ Unloading Balance: } & $\begin{array}{l}\text { Mettler } \\
\text { PM4000 }\end{array}$ & $4000 \mathrm{~g}$ & $0.01 \mathrm{~g}$ & $+/-0.06 \mathrm{~g}$ & & & & & \\
\hline
\end{tabular}

Source: Lowry 2001b, p. 25; Lowry 2001c, p. 41. 
Table 13. Column Test $3 \mathrm{CO}_{2}$ Analysis

\begin{tabular}{|c|c|c|c|c|c|c|c|c|c|c|}
\hline Date & $\begin{array}{c}\text { Column } \\
\text { Pressure } \\
\text { CT1-PRES1 }\end{array}$ & \begin{tabular}{|c|} 
Column \\
Temperature \\
CT1-RTD09
\end{tabular} & $\begin{array}{l}\text { Cooling Cap } \\
\text { Temperature } \\
\text { CT1-RTD11 }\end{array}$ & $\begin{array}{l}\text { Room } \\
\text { Temperature } \\
\text { CT1-TEMP }\end{array}$ & $\begin{array}{c}\text { Ambient } \\
\mathrm{CO}_{2}\end{array}$ & 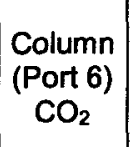 & $\begin{array}{c}\text { Estimated } \\
\text { Air Sample } \\
\text { Volume }\end{array}$ & $\begin{array}{l}\text { Steam } \\
\text { Vent } \\
\mathrm{CO}_{2}\end{array}$ & $\begin{array}{l}\text { Calculated } \\
\text { Water Loss }\end{array}$ & $\begin{array}{l}\text { Converted } \\
\text { Column (CT1- } \\
\text { RTD09) } \\
\text { Temperature }\end{array}$ \\
\hline & mbar & $\operatorname{deg} C$ & & $\operatorname{deg} C$ & $\% \mathrm{CO}_{2}$ & $\% \mathrm{CO}_{2}$ & $\mathrm{ml}$ & $\% \mathrm{CO}_{2}$ & g & $\mathbf{F}$ \\
\hline $9 / 25 / 00 \quad 14: 02$ & See note 1 & 93.0251 & See note 1 & See note 1 & 0.045 & 8.21 & 300 & 0.08 & See note 1 & 199.4 \\
\hline $12 / 6 / 00 \quad 17: 02$ & \begin{tabular}{|r|}
951.540 \\
\end{tabular} & 94.5951 & 22.3865 & 22.8915 & 0.051 & 14.73 & 400 & 0.17 & $\begin{array}{r}681.0 \\
\end{array}$ & 202.3 \\
\hline $12 / 18 / 0014: 20$ & 964.095 & 93.9463 & 23.8611 & 23.7921 & 0.052 & 8.89 & 500 & 0.05 & 1451.5 & 201.1 \\
\hline $12 / 19 / 00 \quad 10: 52$ & 957.920 & 94.3165 & 23.0979 & 24.3384 & 0.076 & 0.19 & 400 & 0.036 & 64.8 & 201.8 \\
\hline $1 / 8 / 015: 02$ & 946.422 & 96.3158 & 22.4045 & 20.4996 & 0.04 & 0.11 & 400 & 0.07 & 604.4 & 205.4 \\
\hline $1 / 9 / 018: 02$ & 945.115 & 90.9612 & 30.6201 & 21.9177 & 0.04 & 0.12 & 400 & 0.12 & 366.4 & 195.7 \\
\hline $1 / 10 / 0110: 02$ & 948.561 & 94.4133 & 44.5091 & 21.6501 & 0.04 & 1.32 & 500 & 0.06 & 396.9 & 201.9 \\
\hline
\end{tabular}

Source: DTN\#MO0109EBSCT3CD.010 for column temperature and pressures; DTN\#MO0107EBSTHCT3.007 for $\mathrm{CO}_{2}$ data.

Table 13. Column Test $3 \mathrm{CO}_{2}$ Analysis (Continued)

\begin{tabular}{|c|c|c|c|c|c|c|c|}
\hline Date & $\begin{array}{c}\text { Steam Sp. } \\
\text { Volume }\end{array}$ & $\begin{array}{c}\text { Converted } \\
\text { Steam Sp. } \\
\text { Volume }\end{array}$ & $\begin{array}{c}\text { Total Volume } \\
\text { of Steam }\end{array}$ & $\begin{array}{c}\text { Adjusted } \\
\text { Volume of Air } \\
\text { at Column } \\
\text { Temperature } \\
\text { (Non-Q) }\end{array}$ & $\begin{array}{c}\text { Air Fraction } \\
(\text { Non-Q) }\end{array}$ & $\begin{array}{c}\text { Air Partial } \\
\text { Pressure (Non } \\
\text { Q) }\end{array}$ & $\begin{array}{l}\text { CO2 Partial } \\
\text { Pressure } \\
\text { (Non-Q) }\end{array}$ \\
\hline & $\mathrm{Ft}^{3} / \mathrm{lbm}$ & $\mathrm{cc} / \mathrm{g}$ & cc & cc & & $\mathrm{Pa}$ & $\mathrm{Pa}$ \\
\hline 9/25/00 14:02 & 34.00 & $2.123 E+03$ & See note 1 & See note 1 & See note 1 & See note 1 & See note 1 \\
\hline $12 / 6 / 0017: 02$ & 32.20 & $2.010 E+03$ & $1.369 \mathrm{E}+06$ & 496.9 & $3.628 \mathrm{E}-04$ & $3.453 \mathrm{E}+01$ & $5.086 \mathrm{E}+00$ \\
\hline $12 / 18 / 0014: 20$ & 32.93 & $2.056 \mathrm{E}+03$ & $2.984 \mathrm{E}+06$ & 618.1 & $2.071 E-04$ & $1.997 \mathrm{E}+01$ & $1.775 \mathrm{E}+00$ \\
\hline $12 / 19 / 00 \quad 10: 52$ & 32.51 & $2.030 \mathrm{E}+03$ & $1.315 \mathrm{E}+05$ & 494.1 & $3.743 E-03$ & $3.585 E+02$ & $6.812 \mathrm{E}-01$ \\
\hline $1 / 8 / 015: 02$ & 30.35 & $1.895 \mathrm{E}+03$ & $1.145 E+06$ & 503.3 & 4.393E-04 & $4.157 E+01$ & 4.573E- 02 \\
\hline 1/9/01 8:02 & 36.56 & $2.282 E+03$ & $8.362 E+05$ & 493.6 & $5.899 \mathrm{E}-04$ & $5.575 E+01$ & $6.690 \mathrm{E}-02$ \\
\hline 1/10/01 10:02 & 32.40 & $2.023 E+03$ & $8.029 E+05$ & 623.4 & $7.759 E-04$ & $7.360 \mathrm{E}+01$ & $9.715 \mathrm{E}-01$ \\
\hline
\end{tabular}

Note: Samples collected on $9 / 25 / 00$ do not have a full set of temperature records due to recording problems with the data system, so not all parameters are calculated. 
Table 14. Operational Parameters and Methods used to Examine ExperimentalC of Compositional Variables for VTGE and Column Test 3

\begin{tabular}{|c|c|c|}
\hline $\begin{array}{l}\text { Operational } \\
\text { Parameter }\end{array}$ & VTGE Methods (Rimstidt and Williamson 1991) & Column Test 3 Methods \\
\hline Energy Balance & $\begin{array}{l}\text { Heater power input controlled at } 250 \text { watts (p. 5) } \\
\text { Heat removal determined at cooling cap (p. 8) } \\
68-75 \% \text { heat removal efficiency (p. 12) }\end{array}$ & $\begin{array}{l}\text { Heater power input controlled at } 400 \text { watts } \\
\text { Heat removal determined at cooling cap } \\
70 \% \text { average heat removal efficiency }\end{array}$ \\
\hline Water Balance & $\begin{array}{l}\text { Water input not measured } \\
\text { Water (steam) output not measured }\end{array}$ & $\begin{array}{l}\text { Water input measured gravimetrically } \\
\text { Water (steam) output measured gravimetrically } \\
\text { Water balance performed with water input matching } \\
\text { output to within } 0.24 \mathrm{~kg}(\mathrm{p} .20)\end{array}$ \\
\hline $\begin{array}{l}\text { Test Material } \\
\text { Classification }\end{array}$ & $\begin{array}{l}\text { Glassy and devitrified (nonlithophysal) Topopah Sring } \\
\text { Tuff (p. \&) }\end{array}$ & $\begin{array}{l}\text { Crystal-poor middle nonlithophysal zone of Topopah } \\
\text { Spring Tuff }\end{array}$ \\
\hline Water Chemistry & $\begin{array}{l}\text { Three water types in separate tests: } \\
\text { Distilled-deionized water (p.8-9) } \\
0.125 \mathrm{ppm} \mathrm{NaCl} \text { solution (p. 9) } \\
\text { Synthetic J13 well water (p. 9) }\end{array}$ & Distilled-deionized water \\
\hline $\begin{array}{l}\text { Geochemical } \\
\text { Analyses }\end{array}$ & $\begin{array}{l}\text { Fluid analysis for major cations, anions, and pH (p. 17) } \\
\text { SEM analysis of tuff surfaces (p. 12) } \\
\text { Geothermometer temperatures calculated (pp. 22-24) }\end{array}$ & $\begin{array}{l}\text { Fluid analysis for major cations, anions, and pH } \\
\text { SEM analysis of tuff surfaces } \\
\text { Quantitative XRD analysis of cement and tuff surfaces }\end{array}$ \\
\hline $\begin{array}{l}\text { Solids Mass } \\
\text { Movement }\end{array}$ & $\begin{array}{l}\text { No apparent solid material mass balance performed } \\
\text { between column sections } \\
\text { Air permeability measurements not performed }\end{array}$ & $\begin{array}{l}\text { Solid material mass balance performed, pre-test and } \\
\text { post-test for discrete lifts } \\
\text { Air permeability measurements performed over column } \\
\text { length, pre- and post-test }\end{array}$ \\
\hline $\begin{array}{l}\text { Temperature } \\
\text { Distribution }\end{array}$ & $\begin{array}{l}\text { Temperatures measured at three column positions, } 9.5 \text {, } \\
32.5 \text {, and } 56.0 \mathrm{~cm} \text { above the column bottom (p. } 8)\end{array}$ & $\begin{array}{l}\text { Temperatures measured at } 10 \text { column positions, } \\
\text { including locations in the plenum above the test } \\
\text { material and in the ball bearing layer above the heated } \\
\text { surface }\end{array}$ \\
\hline $\begin{array}{l}\text { Data Acquisition } \\
\text { and Collection } \\
\text { Frequency }\end{array}$ & Manual data acquisition of temperature (p. 6 and 9 ) & $\begin{array}{l}\text { All instruments were measured with electronic data } \\
\text { acquisition system, collection period was nominally } \\
1 \text { hour }\end{array}$ \\
\hline Operation Time & $\begin{array}{l}\text { Seven experimental runs with Yucca Mountain tuff, } \\
\text { average run time was } 507.9 \text { hours, the longest run was } \\
625 \text { hours }(p .10)\end{array}$ & $\begin{array}{l}\text { One experimental run with Yucca Mountain tuff, run } \\
\text { time was } 2357.8 \text { hours } \\
\text { Two previous tests performed with Yucca Mountain tuff } \\
\text { contaminated with asphalt and non-YMP materials }\end{array}$ \\
\hline
\end{tabular}




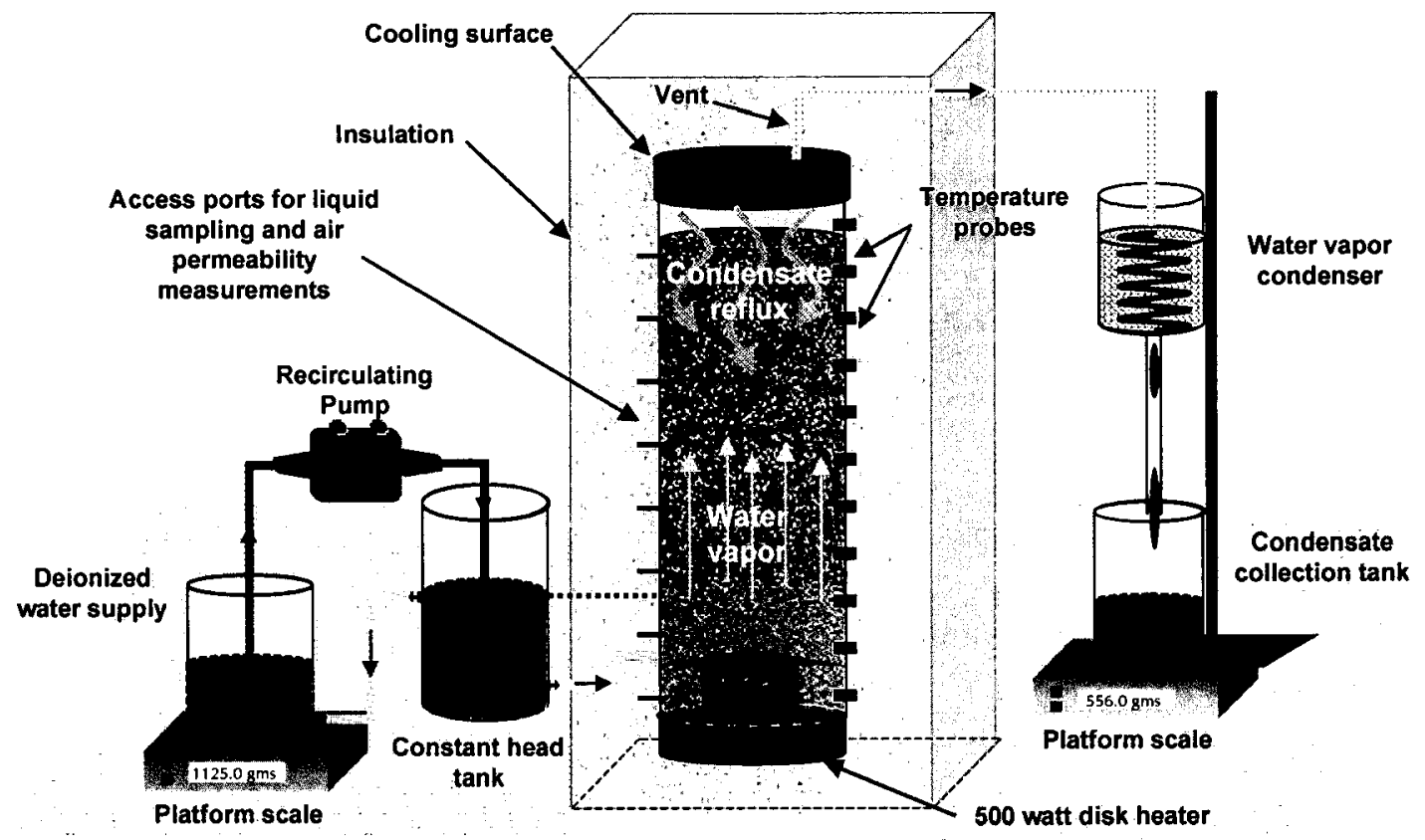

Source: Modified from CRWMS M\&O 2000, p. 8.

Figure 1. General THC Column Test Configuration 

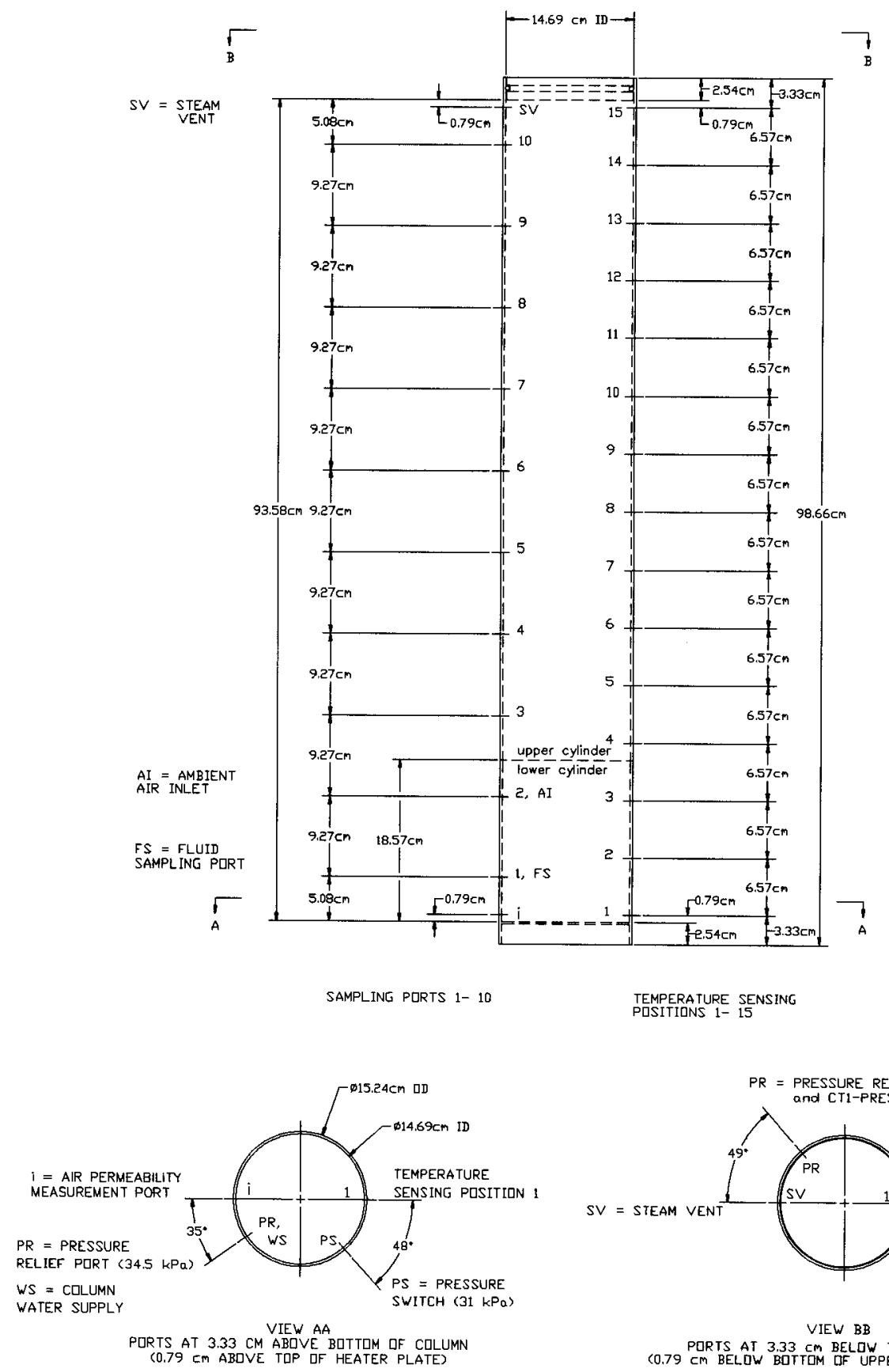

TEMPERATURE SENSING
PISITIONS $1-15$

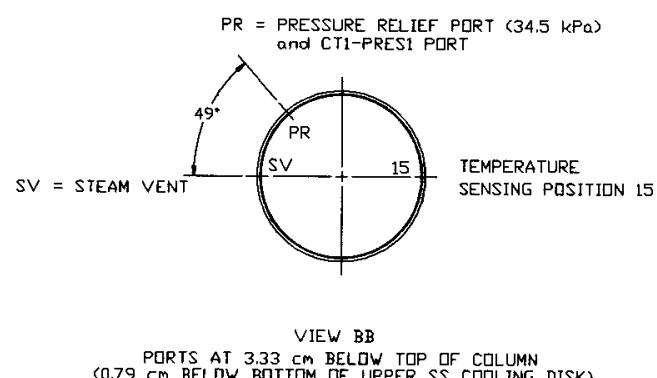

Source: Lowry 2001c, p. 62.

Figure 2. Column Construction Details 


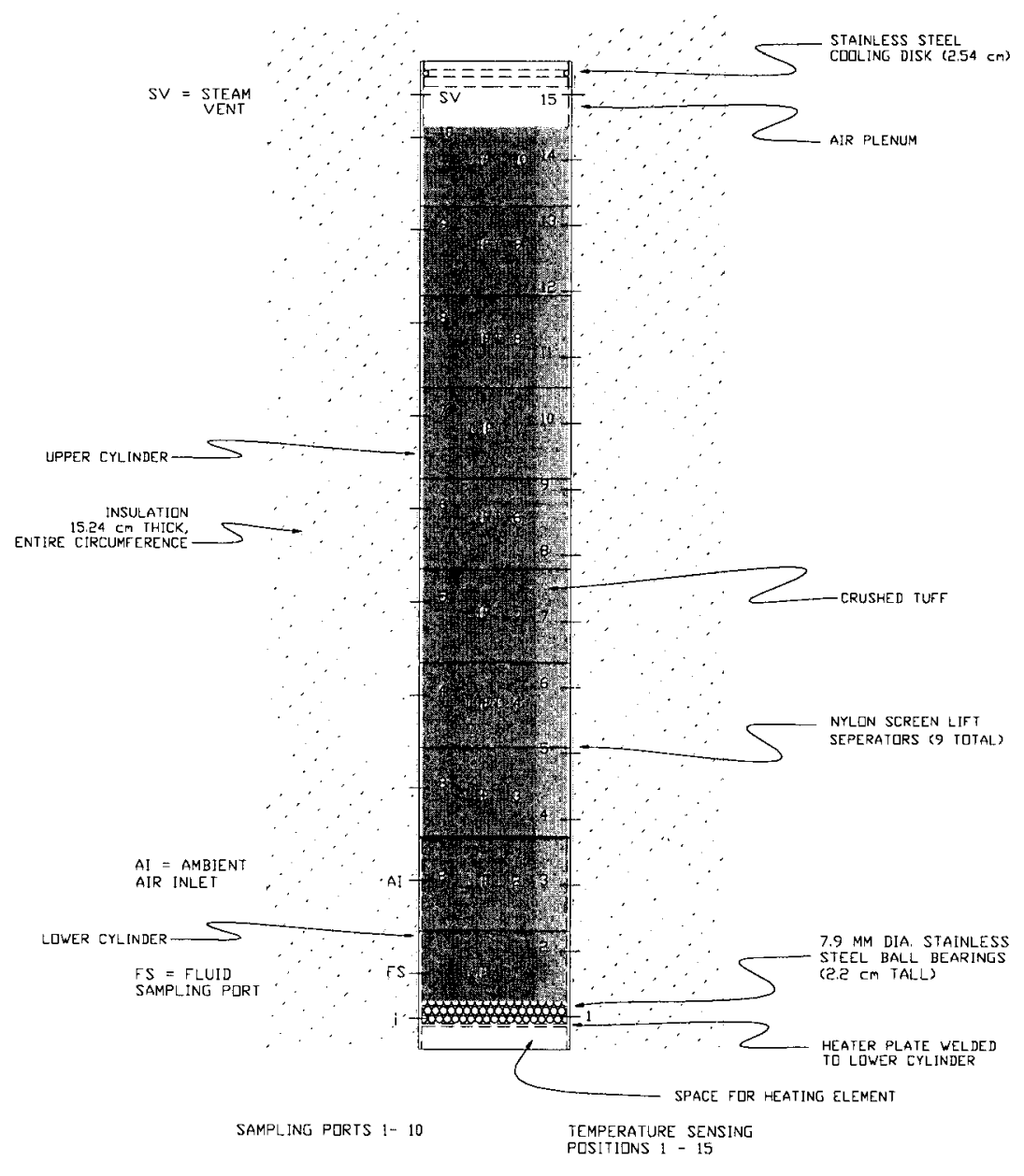

Source: Lowry 2001c, p. 63.

Figure 3. Column Assembly and Insulation Configuration 


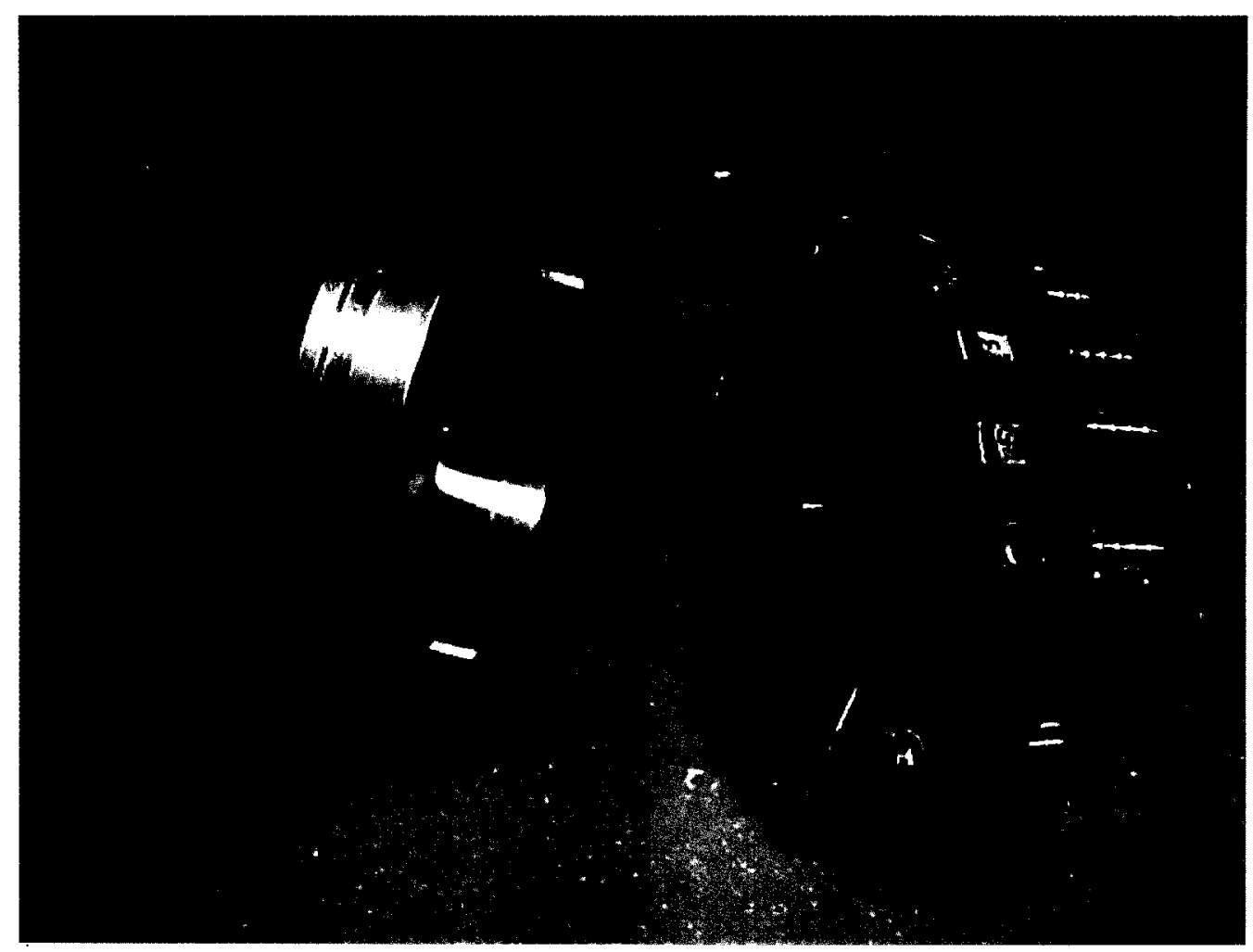

Source: Lowry 2001c, p. 64.

Figure 4. Cooling Disk 


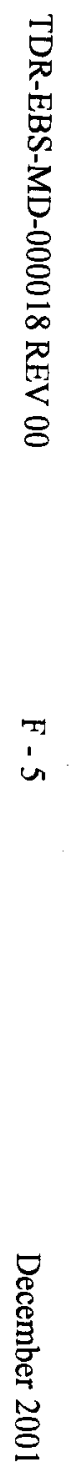

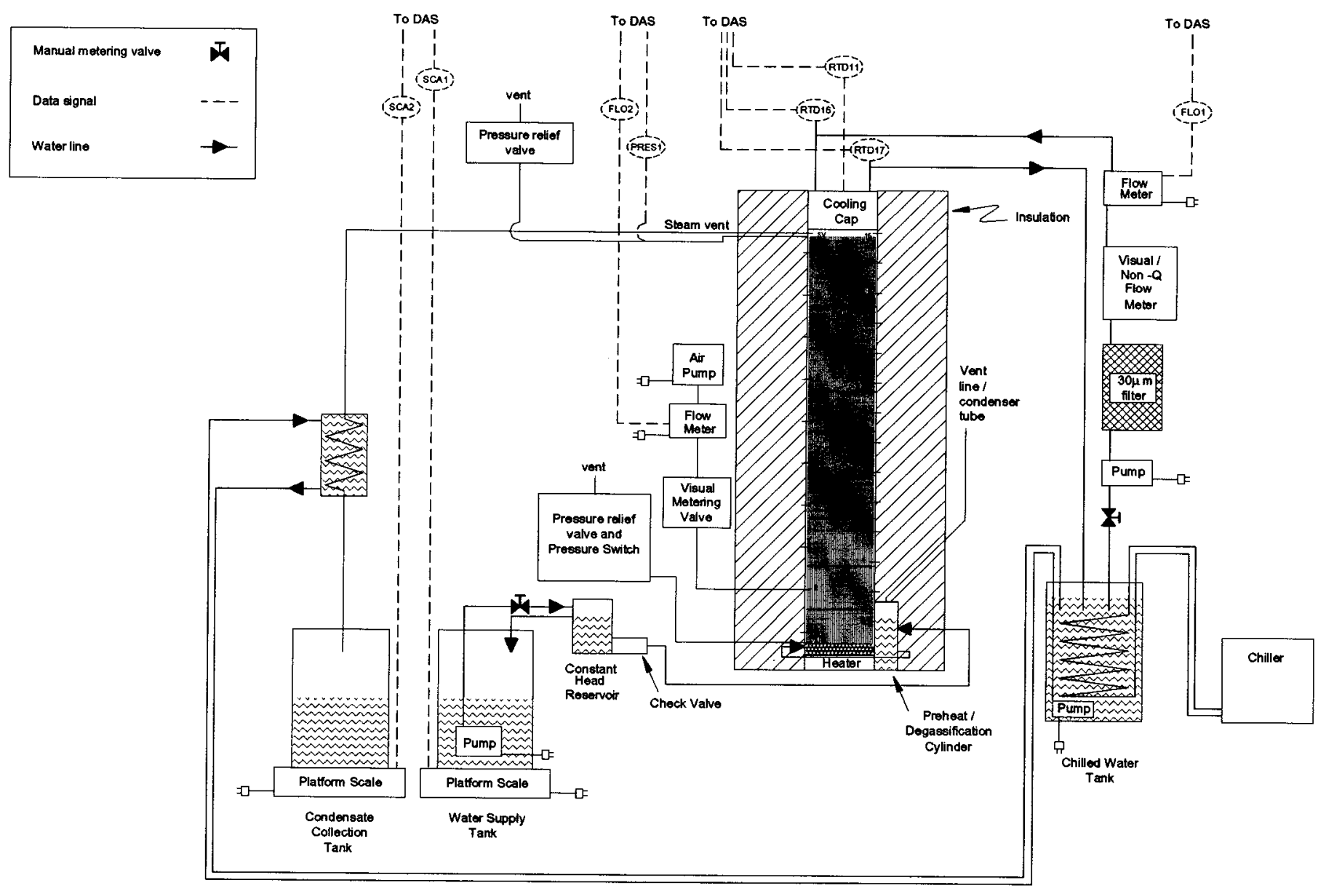

Source: Lowry 2001c, p. 5.

Figure 5. Column Process Flow Schematic 


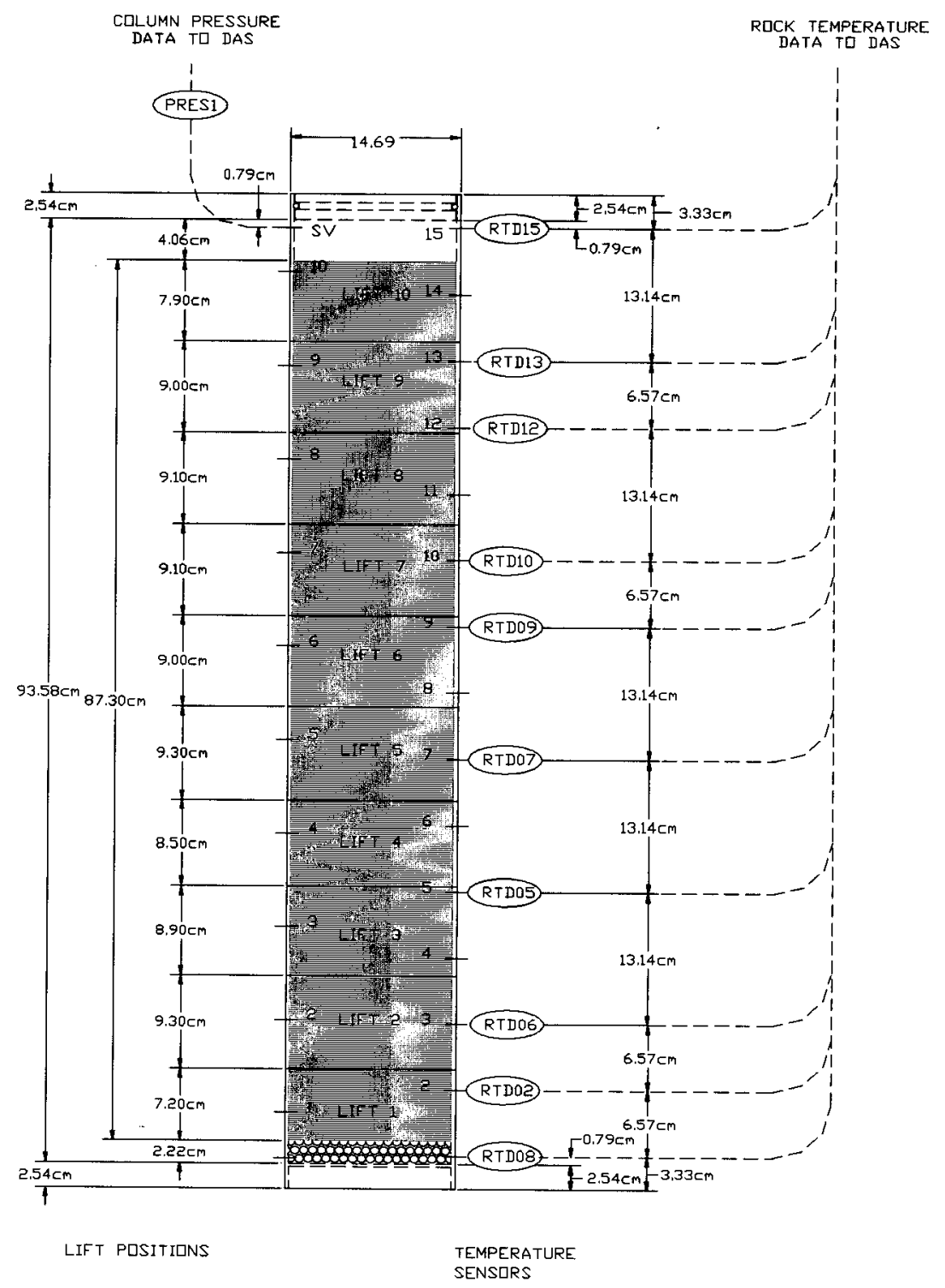

Source: Lowry 2001c, p. 4.

Figure 6. Column Test 3 RTD and Lift Locations 


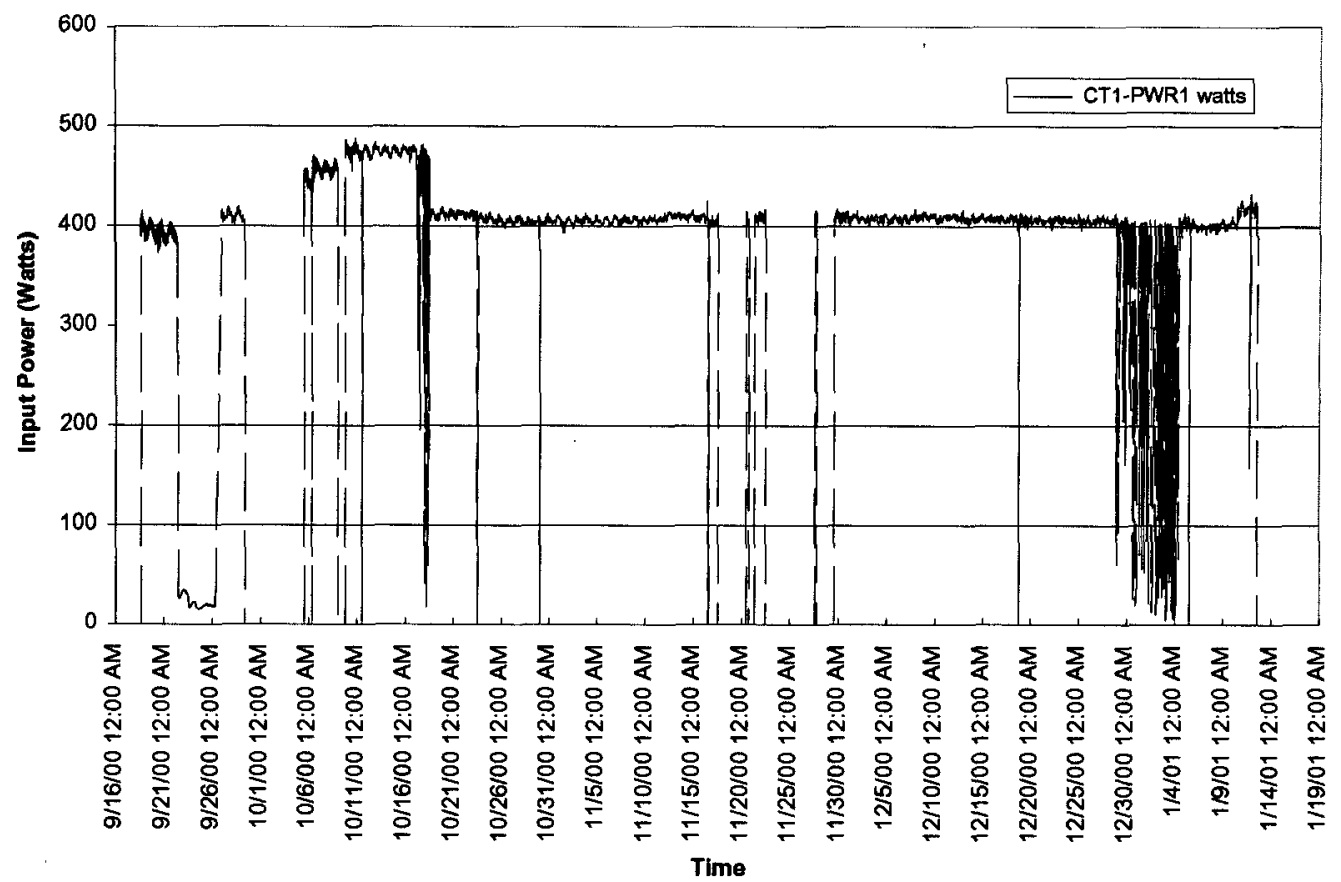

Source: Lowry 2001c, p. 16; DTN\#MO0107EBSTHCT3.007.

Figure 7. Column Test No. 3 Heater Input

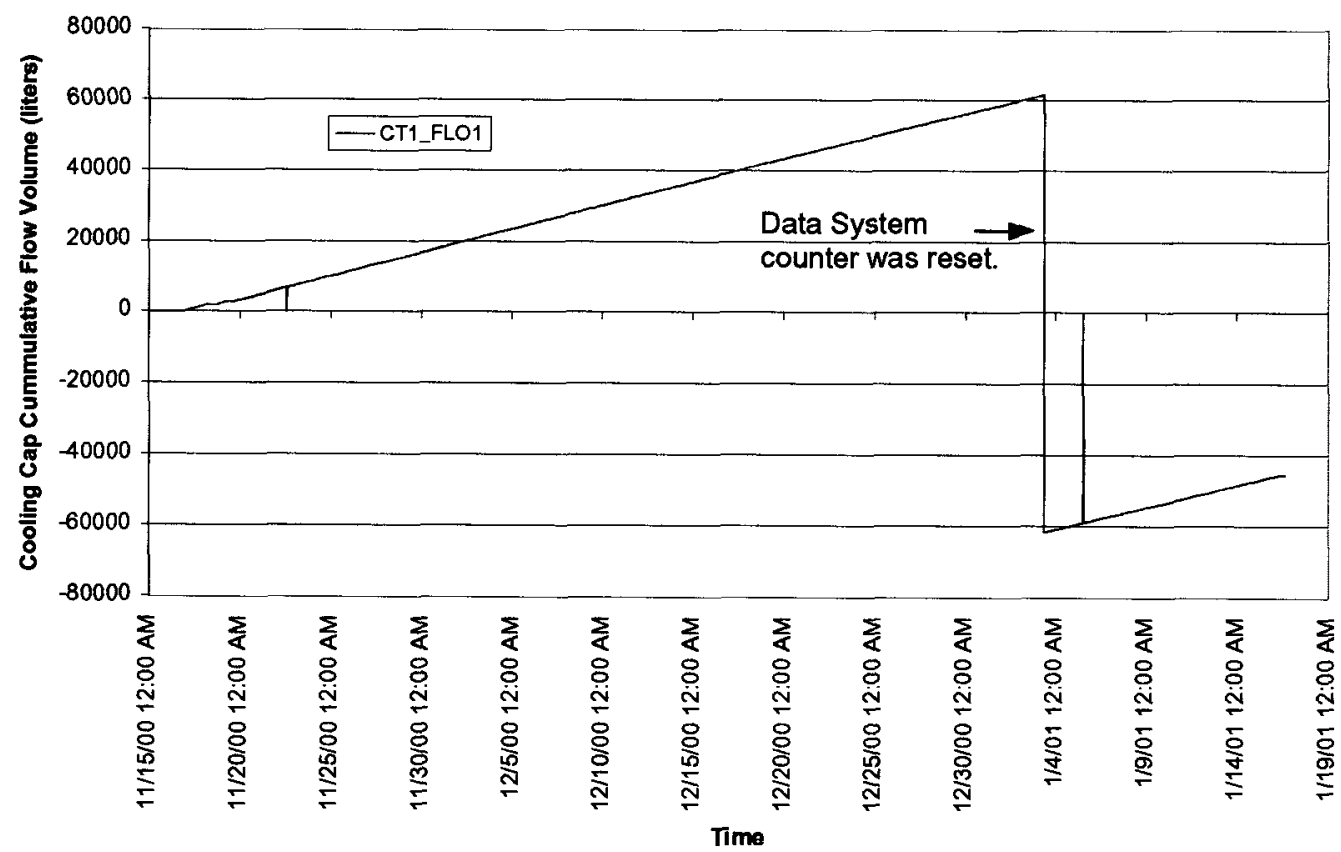

Source: Lowry 2001c, p. 13; DTN\#MO0107EBSTHCT3.007.

Figure 8. Column Test No. 3 Cooling Cap Flow Measured as Volume 


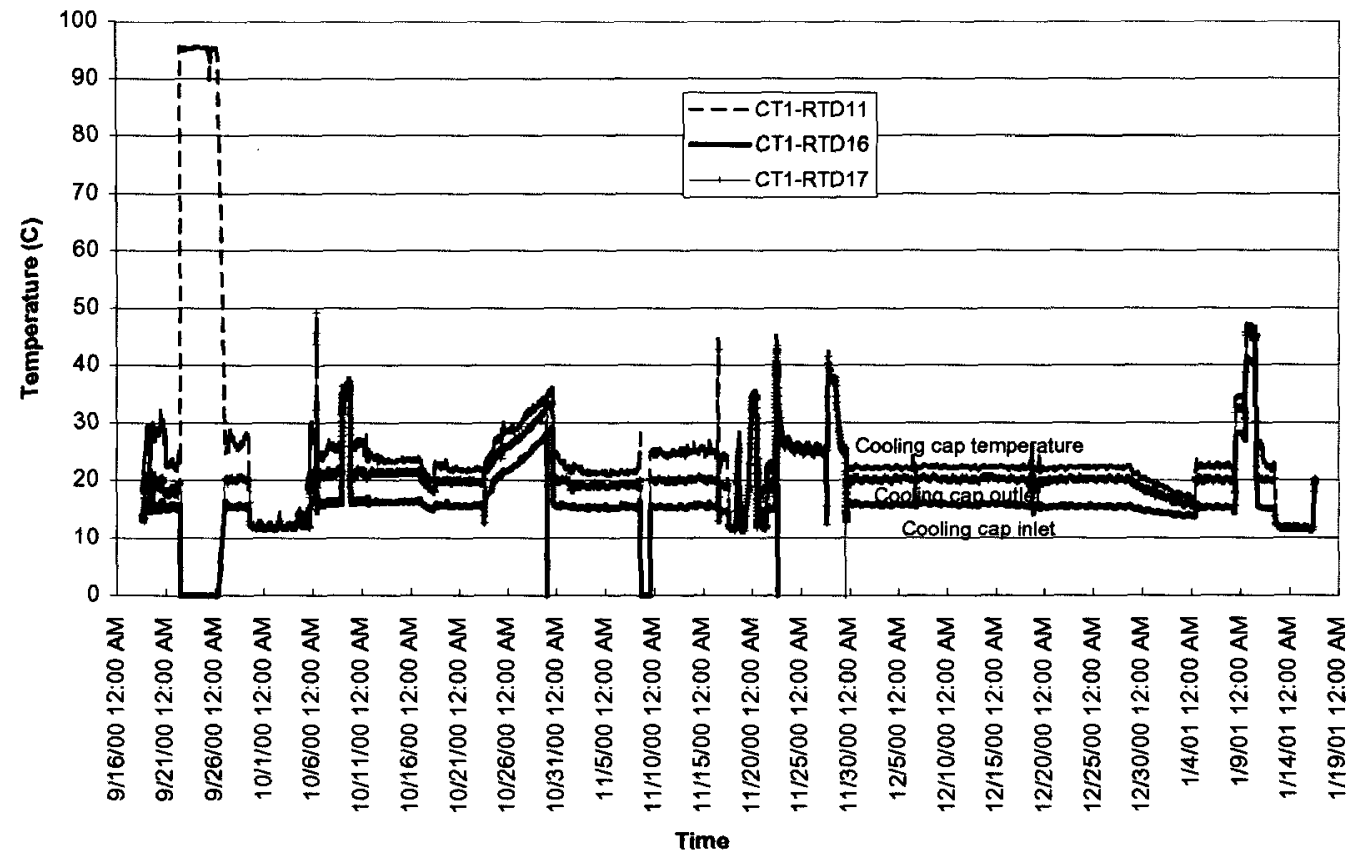

Source: Lowry 2001c, p. 13; DTN\#MO0107EBSTHCT3.007.

Figure 9. Column Test No. 3 Cooling Cap Temperature

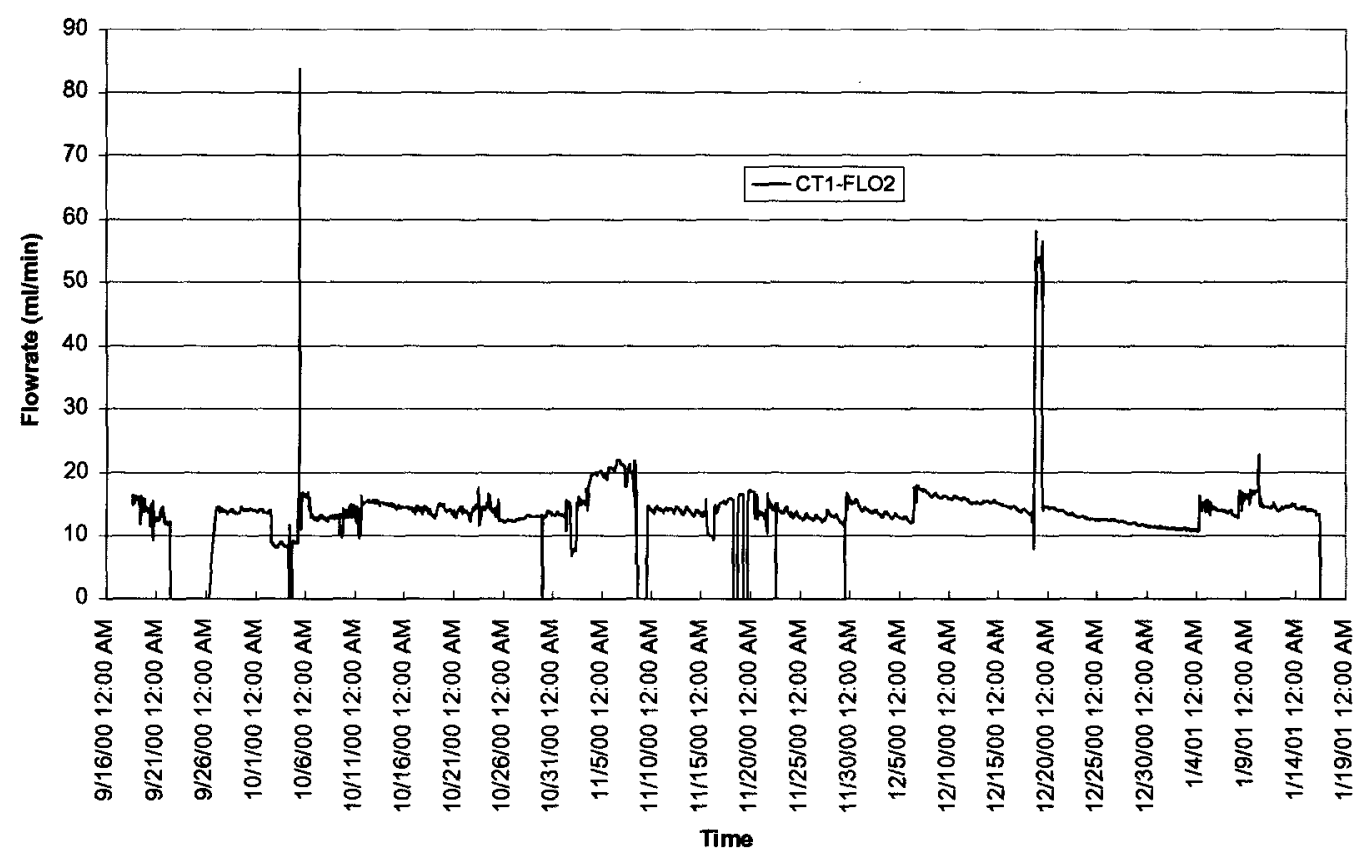

Source: Lowry 2001c, p. 14; DTN\#MO0107EBSTHCT3.007.

Figure 10. Column Test No. 3 Injection Air Flow 


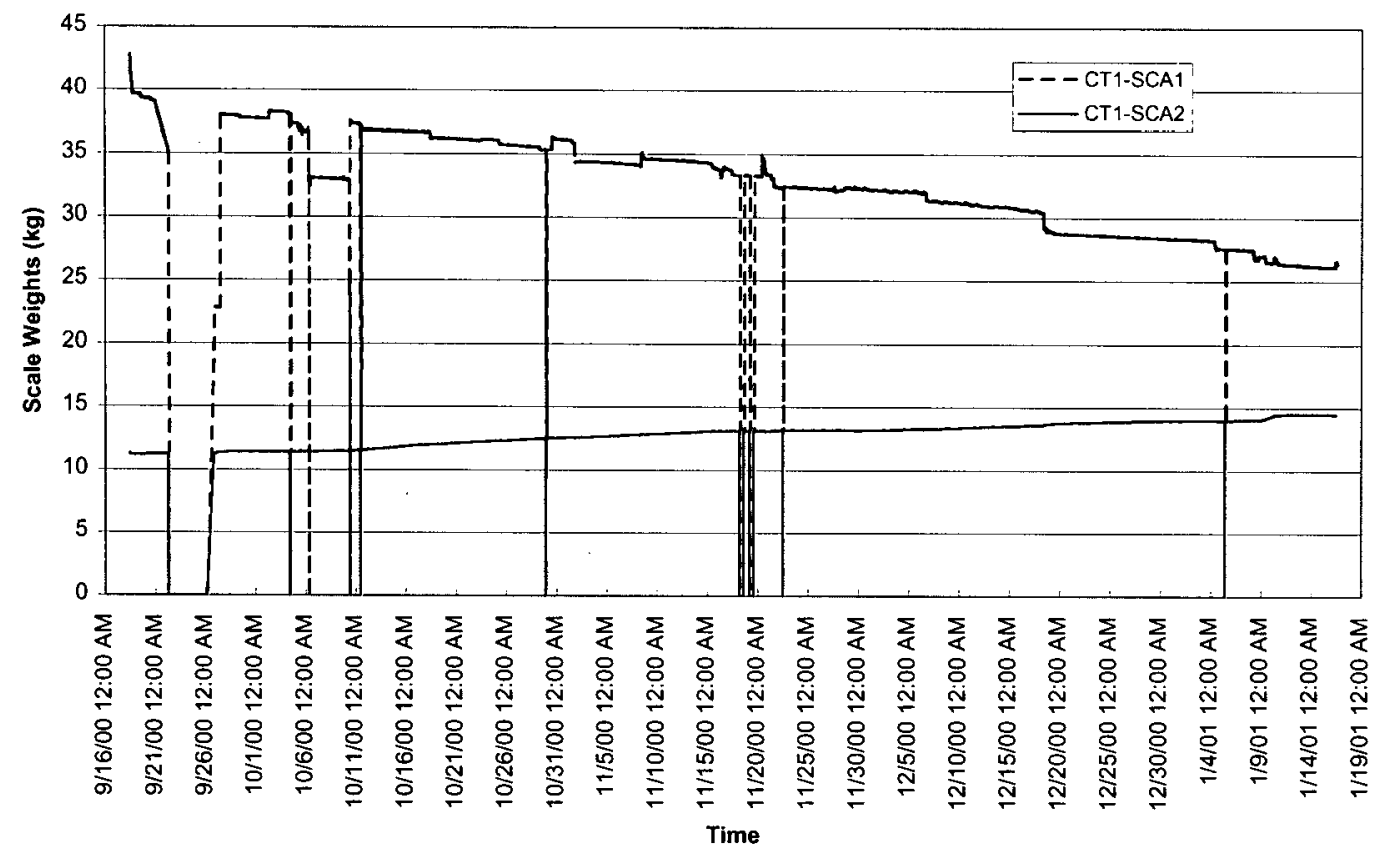

Source: Lowry 2001c, p. 14; DTN\#MO0107EBSTHCT3.007.

Figure 11. Column Test No. 3 Water Supply and Condensate Collection Scales

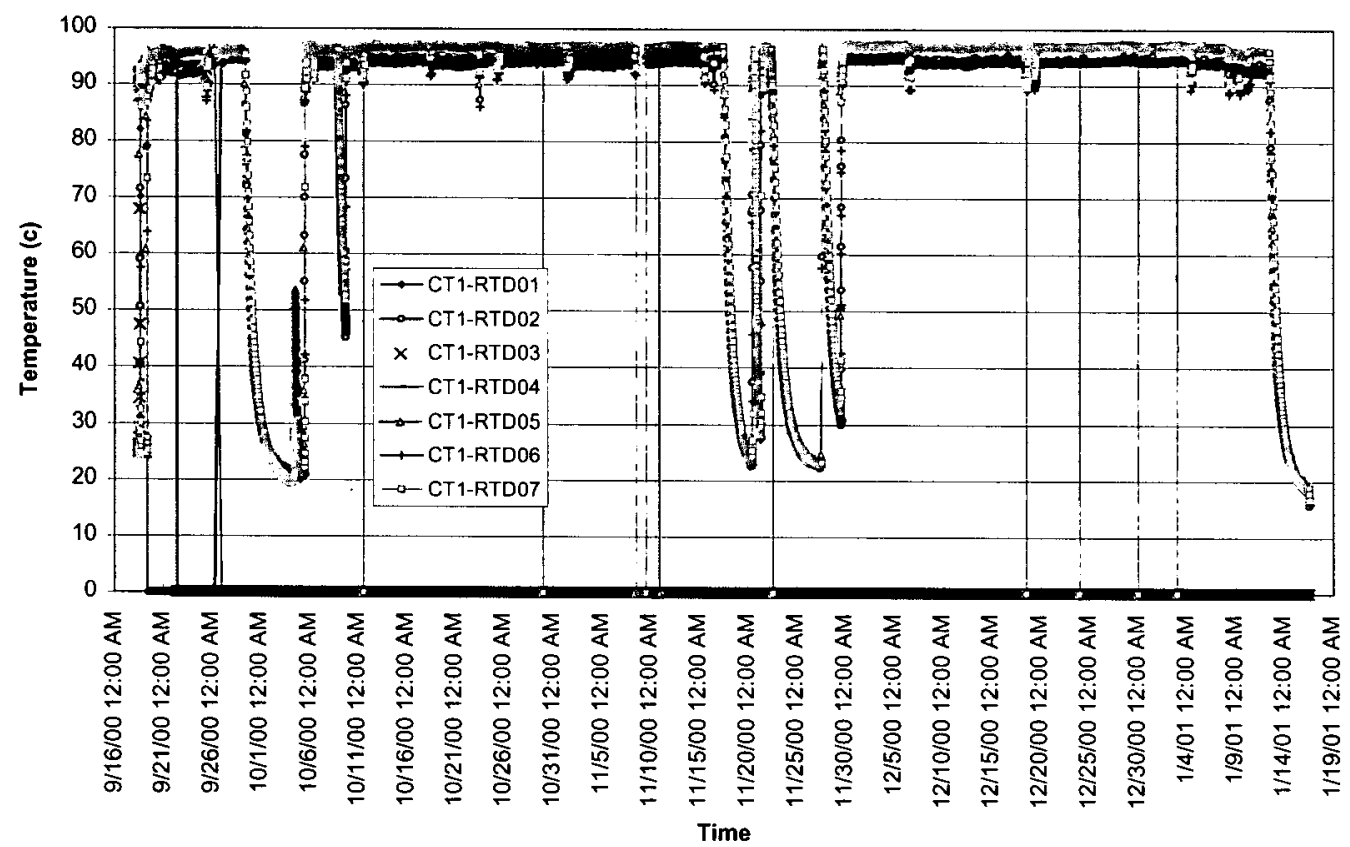

Source: Lowry 2001c, p. 15; DTN\#MO0107EBSTHCT3.007.

Figure 12. Column Test No. 3 Column Temperature (Bottom Half) 


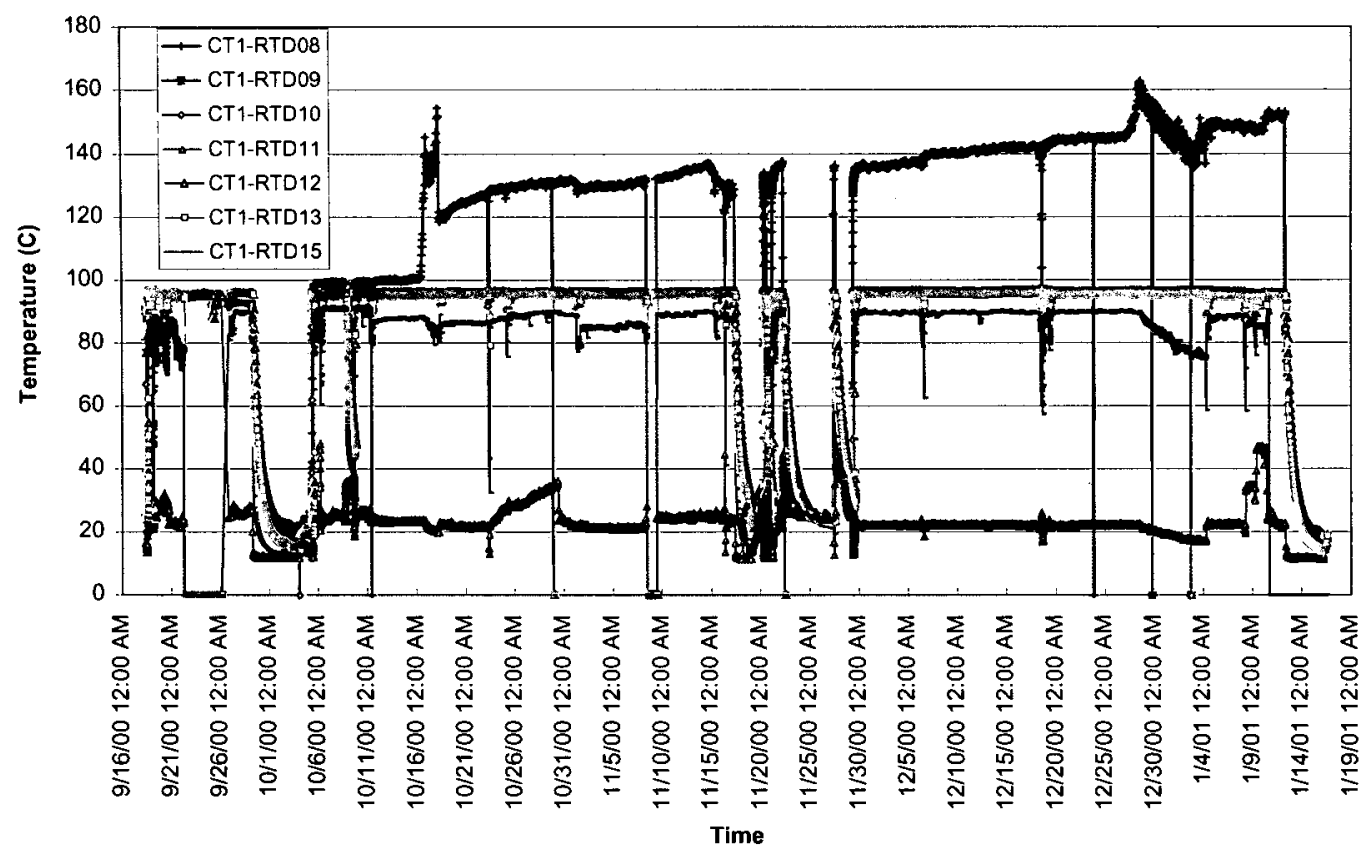

Source: Lowry 2001c, p. 15; DTN\#MO0107EBSTHCT3.007.

Figure 13. Column Test No. 3 Column Temperatures (Top Half) 


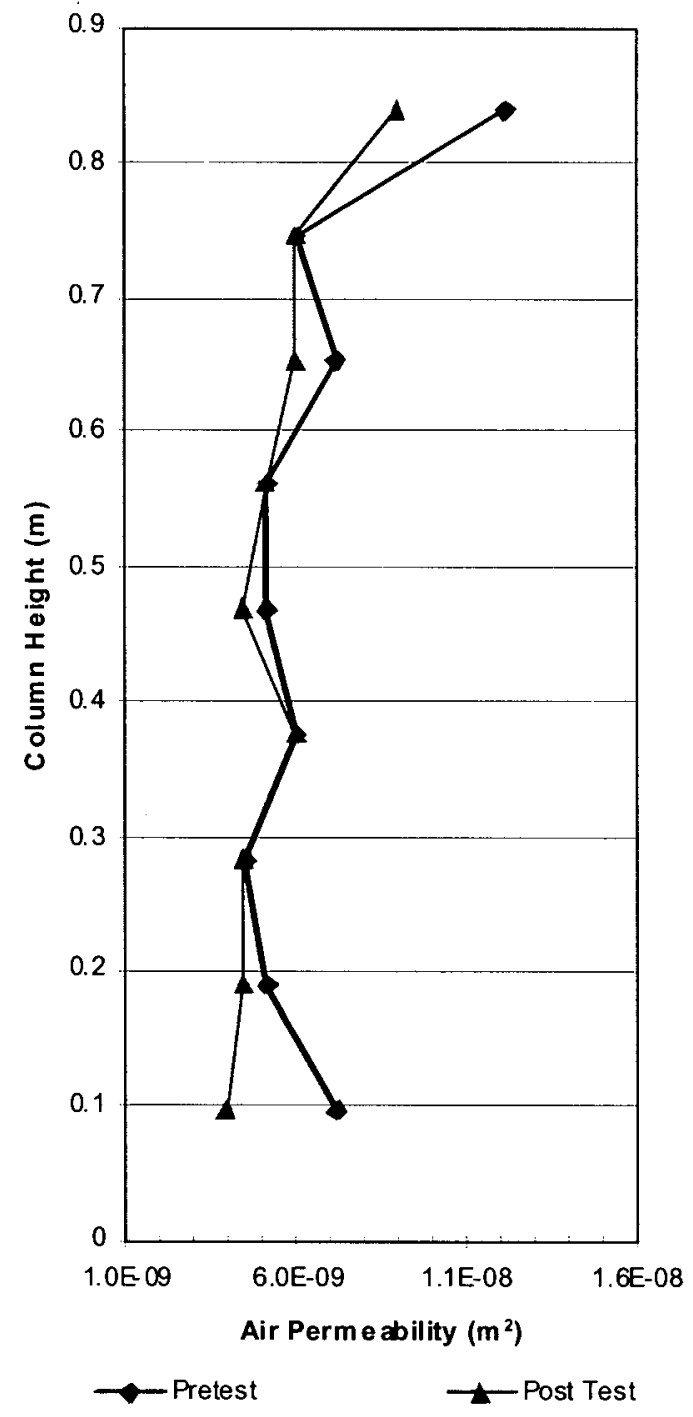

Source: Lowry 2001b, p. 159; DTN\#MO0106EBSCT3AP.004.

Figure 14. Air Permeability Measurements of Column Test No.3 


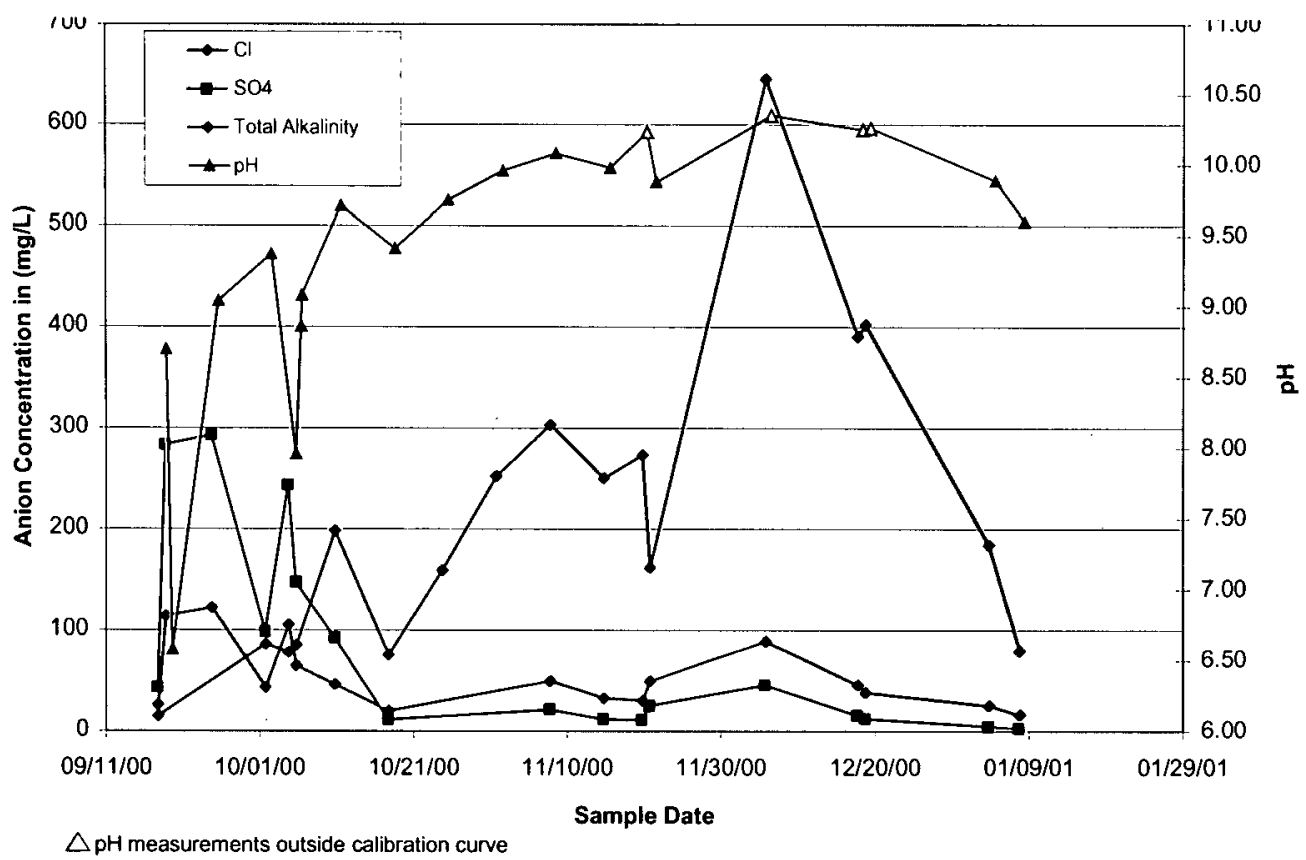

Source: Lowry 2001c, p. 39; DTN\#LA0106ZW831234.009; DTN\#LA0106ZW831234.005;

DTN\#MO0106EBSCT3PH.006; DTN\#LA0106ZW831234.001; DTN\#MO0106EBSCT3PH.005.

Figure 15. Column Test No. 3 Anion Concentration with Total Alkalinity and pH

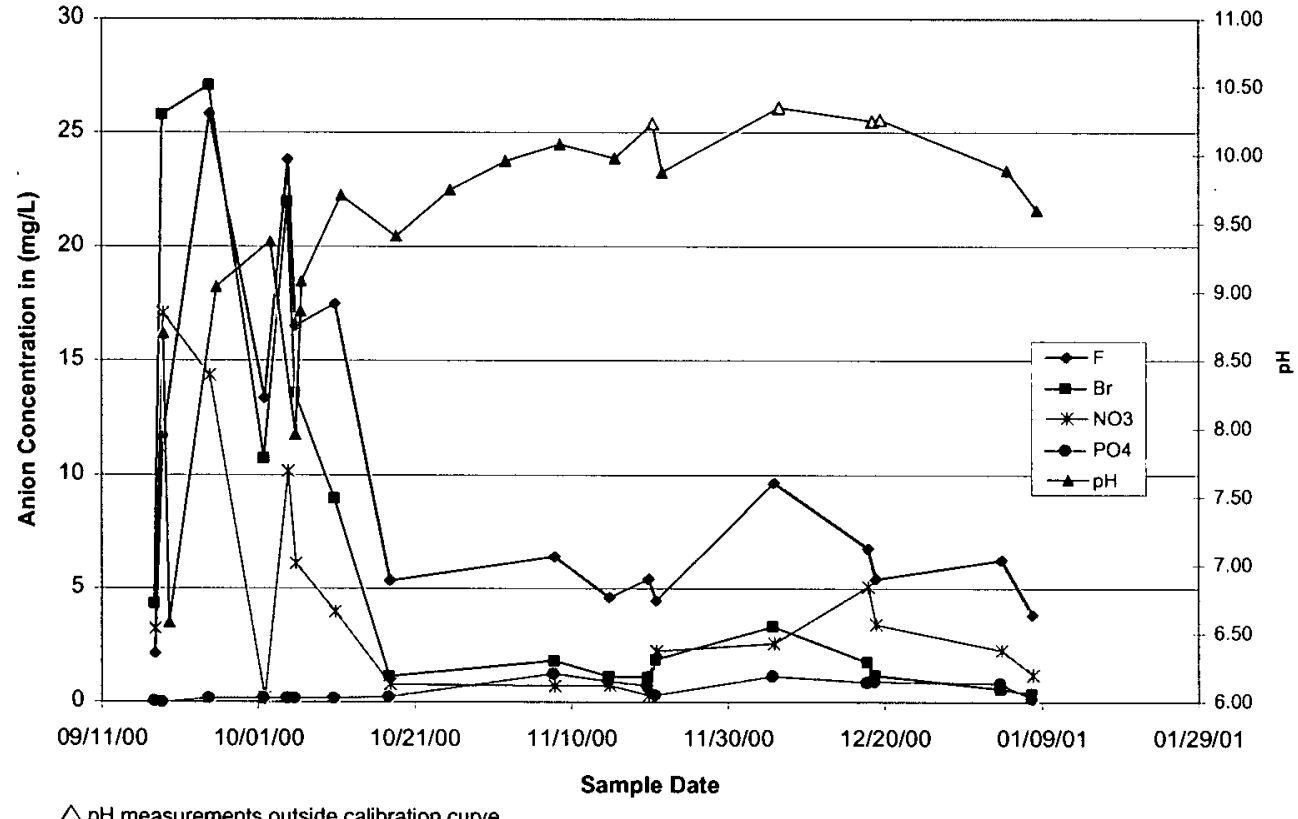

Source: Lowry 2001c, p. 40; DTN\#LA0106ZW831234.004; DTN\#LA0106ZW831234.007;

DTN\#LA0106ZW831234.006; DTN\#LA0106ZW831234.008; DTN\#MO0106EBSCT3PH.005;

DTN\#MO0106EBSCT3PH.006.

Figure 16. Column Test No. 3 Anion Concentration with $\mathrm{pH}$ 


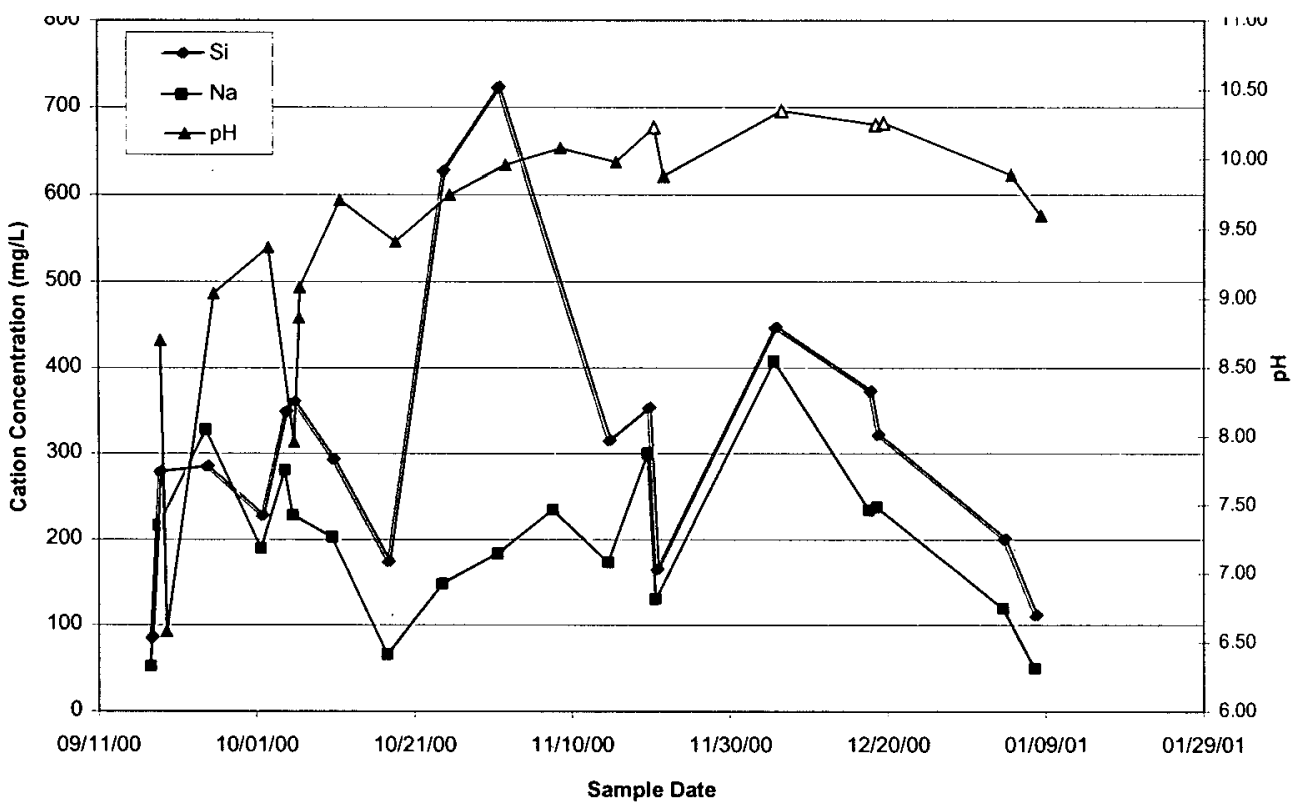

$\triangle \mathrm{pH}$ measurements outside calibration curve

Source: Lowry 2001c, p. 37 DTN\#LA0106ZW831234.002; DTN\#MO0106EBSCT3PH.005; DTN\#MO0106EBSCT3PH.006.

Figure 17. Column Test No. 3 Cation Concentration with pH

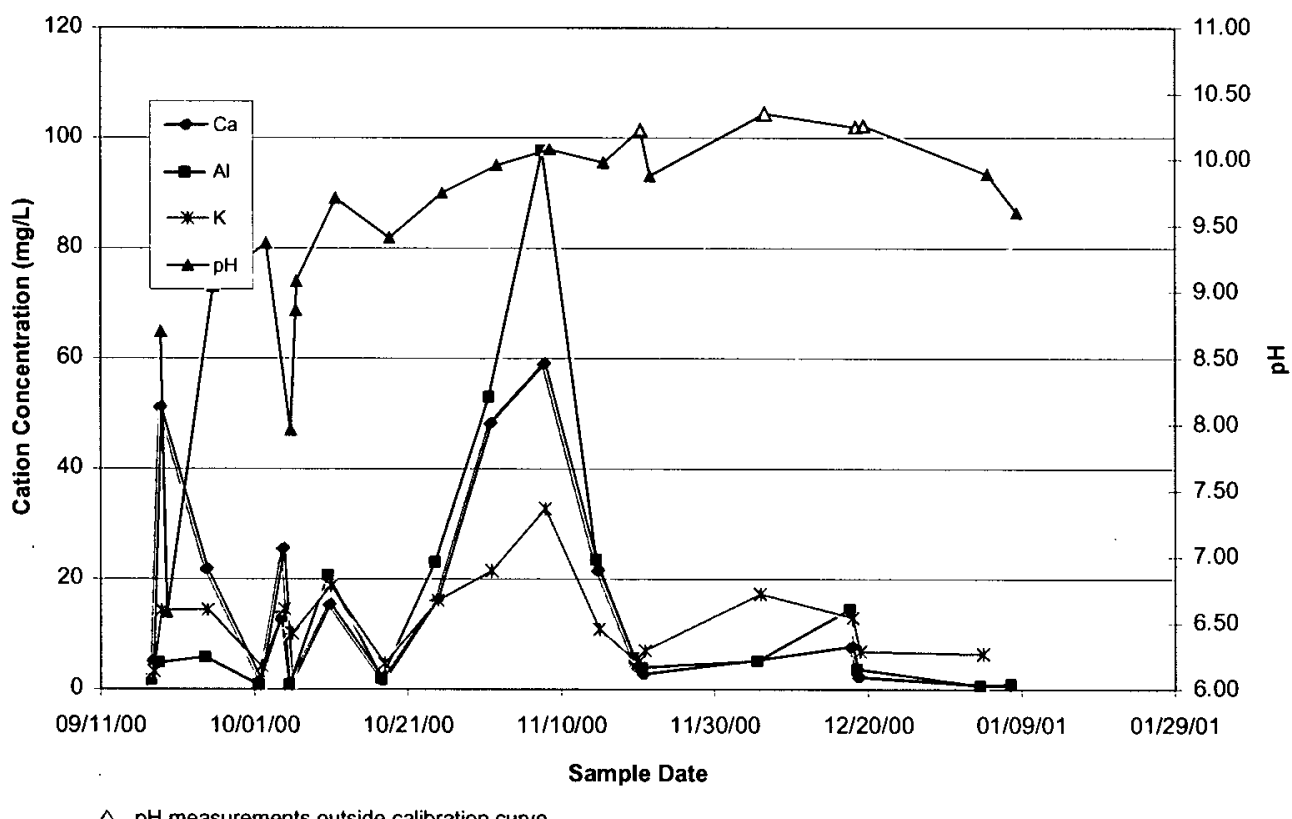

$\triangle \mathrm{pH}$ measurements outside calibration curve

Source: Lowry 2001c, p. 38; DTN\#LA0106ZW831234.002; DTN\#LA0106ZW831234.003;

DTN\#MO0106EBSCT3PH.005; DTN\#MO0106EBSCT3PH.006.

Figure 18. Column Test No. 3 Cation Concentration with $\mathrm{pH}$ 


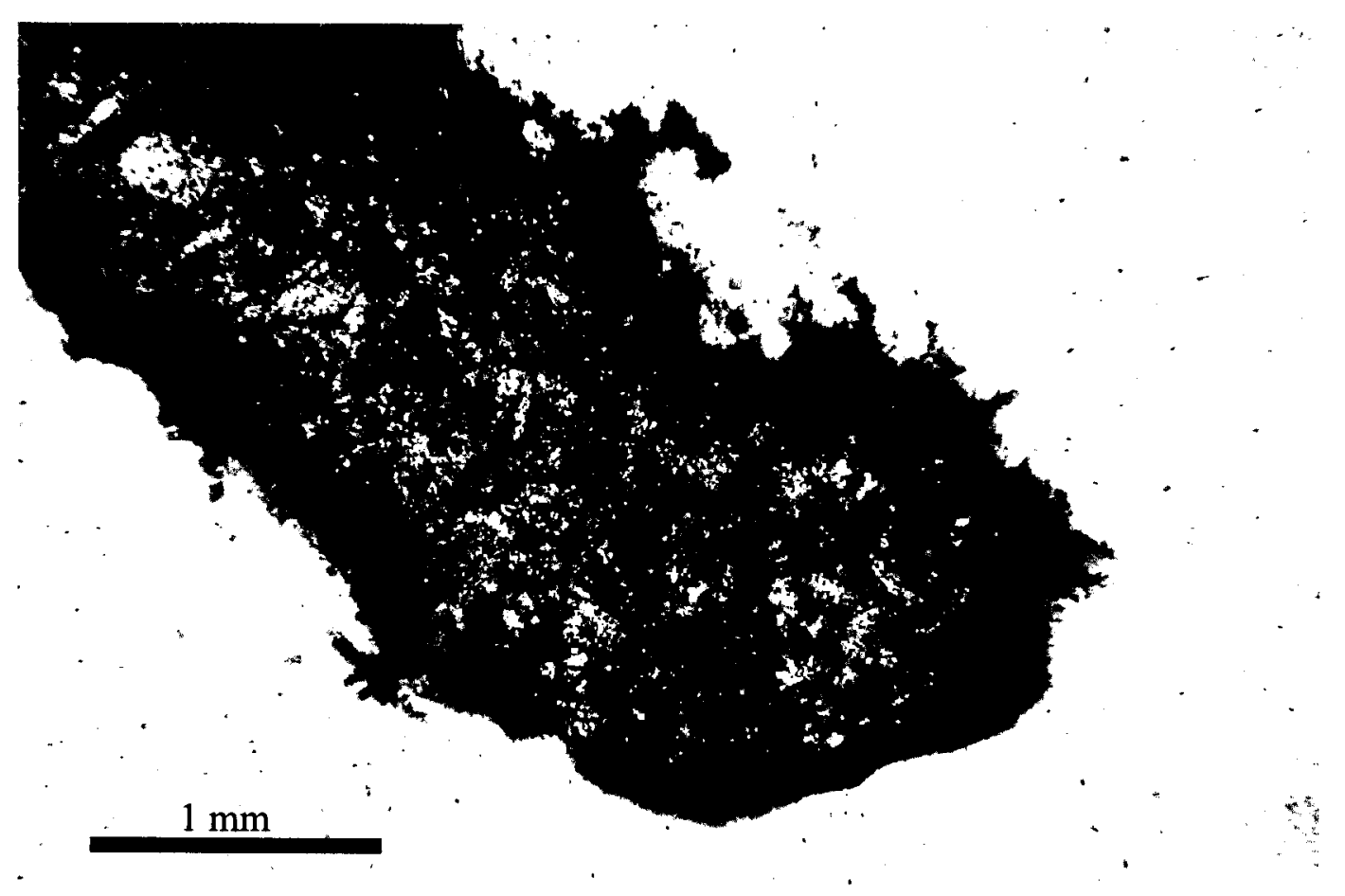

Source: Peterman 2001, p. 6; Lowry 2001c, p. 46.

Figure 19. Reaction Rims Along Grain Boundaries, Samples from Lift 1 (SMF\#00573024) 


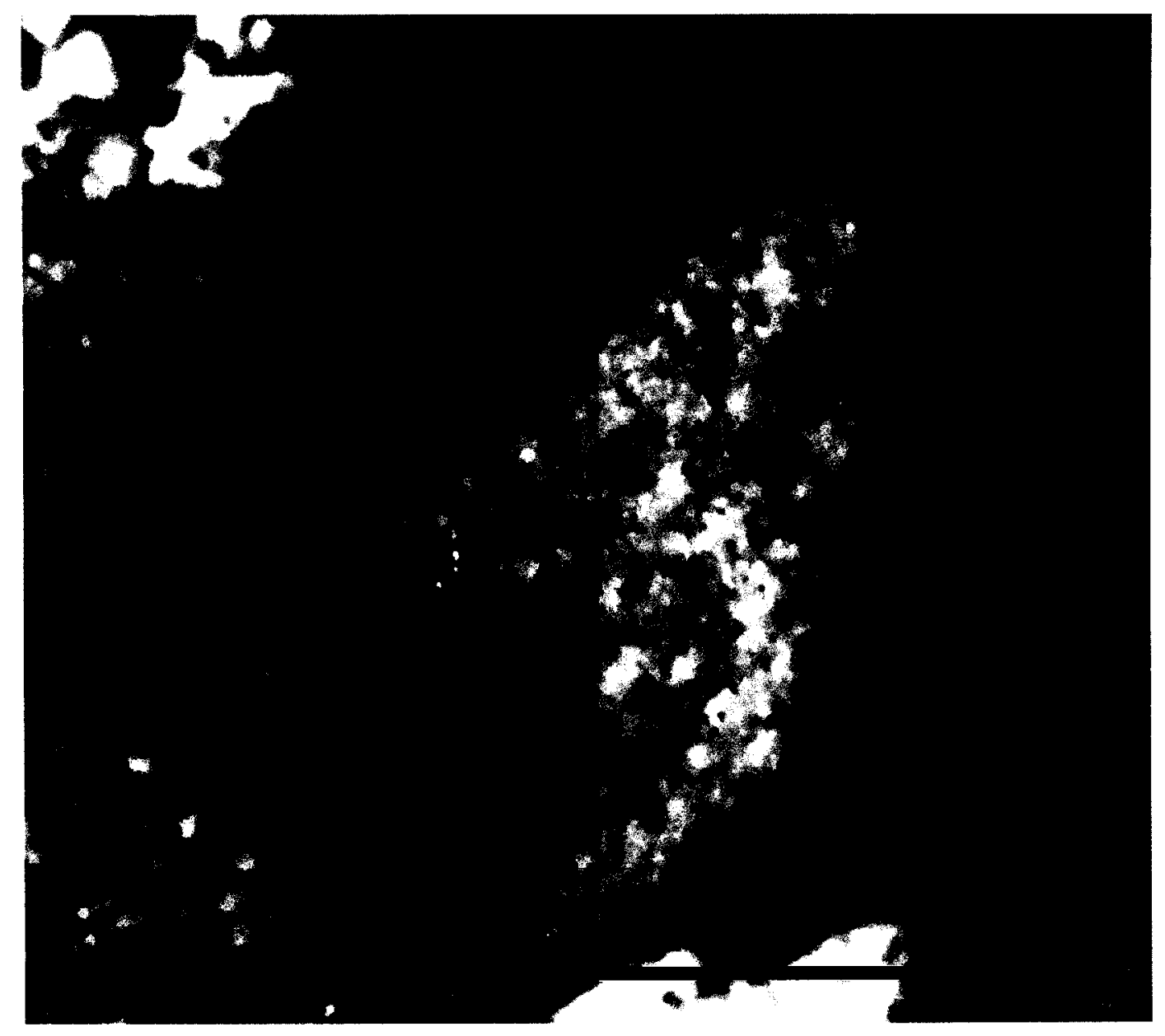

Source: Peterman 2001, p. 5; Lowry 2001c, p. 48.

Figure 20. Secondary-Minerals in Sample from Lift 1 (SMF\#00573024) 


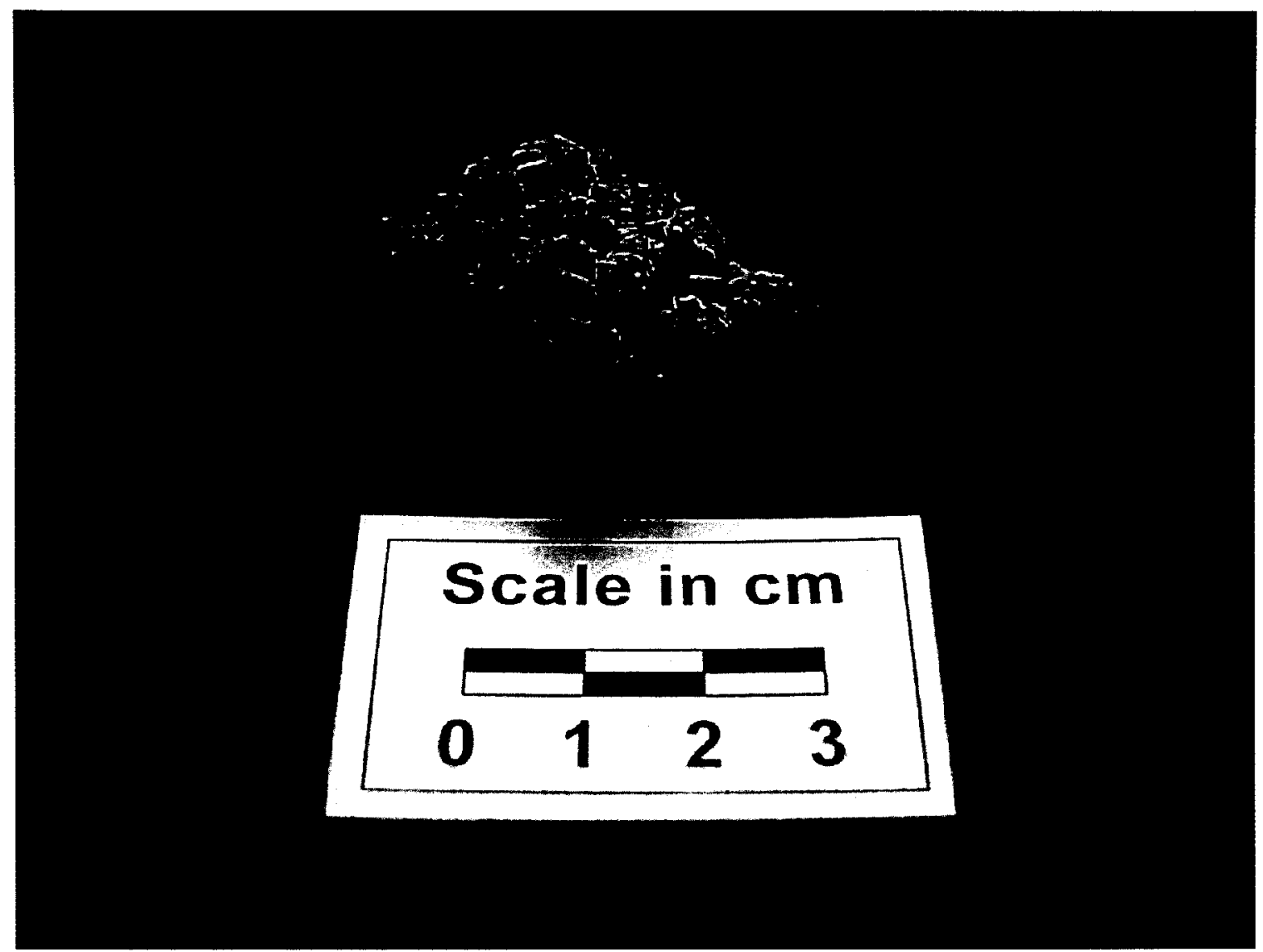

Source: Lowry 2001c, p. 51.

Figure 21. Cemented Rock Mass, Lift 1 


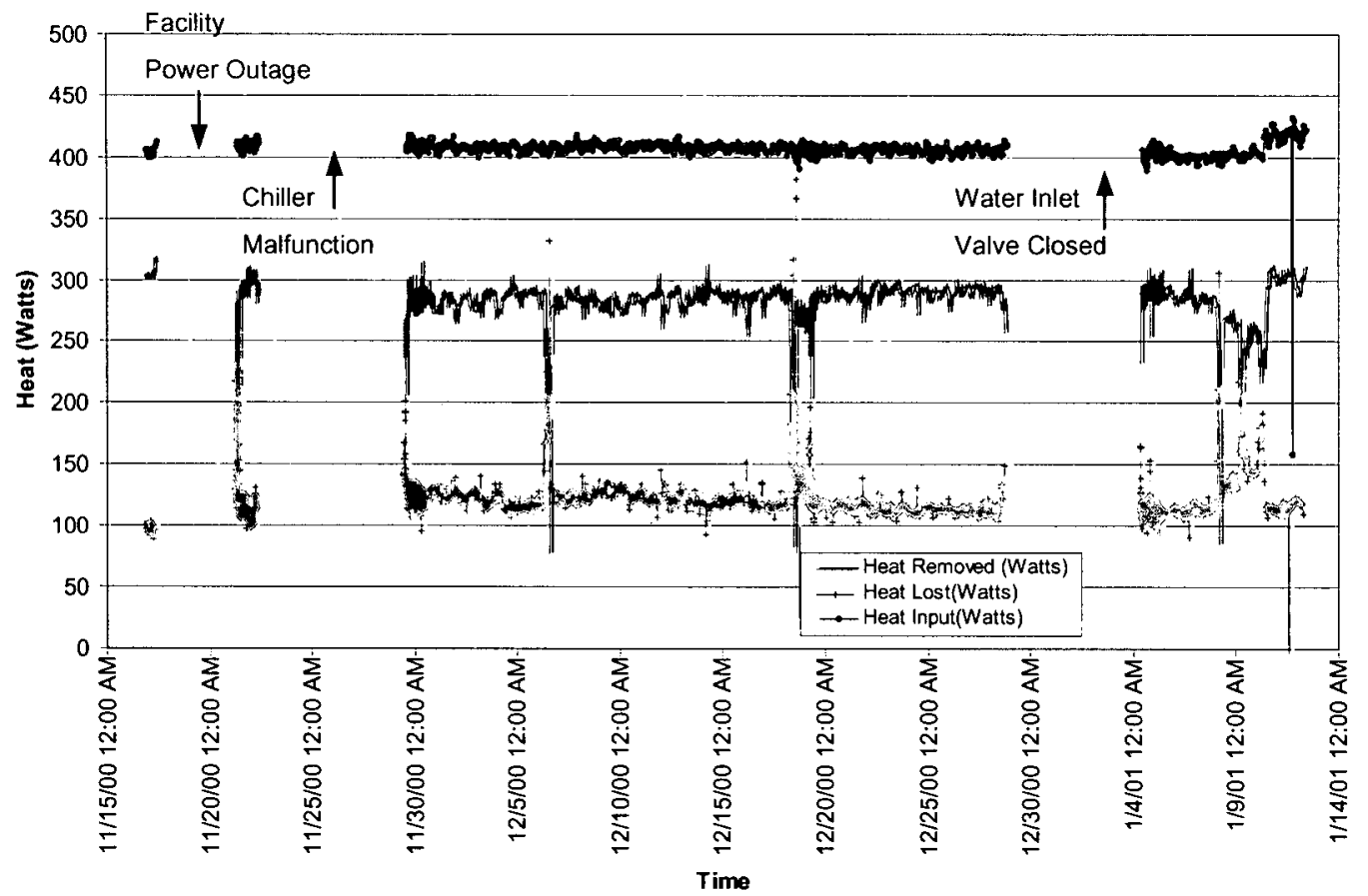

Source:.Lowry 2001c, p. 65; DTN\#M00109EBSCT3HD.008.

Figure 22. Column Test 3 Cooling Cap Heat Removal

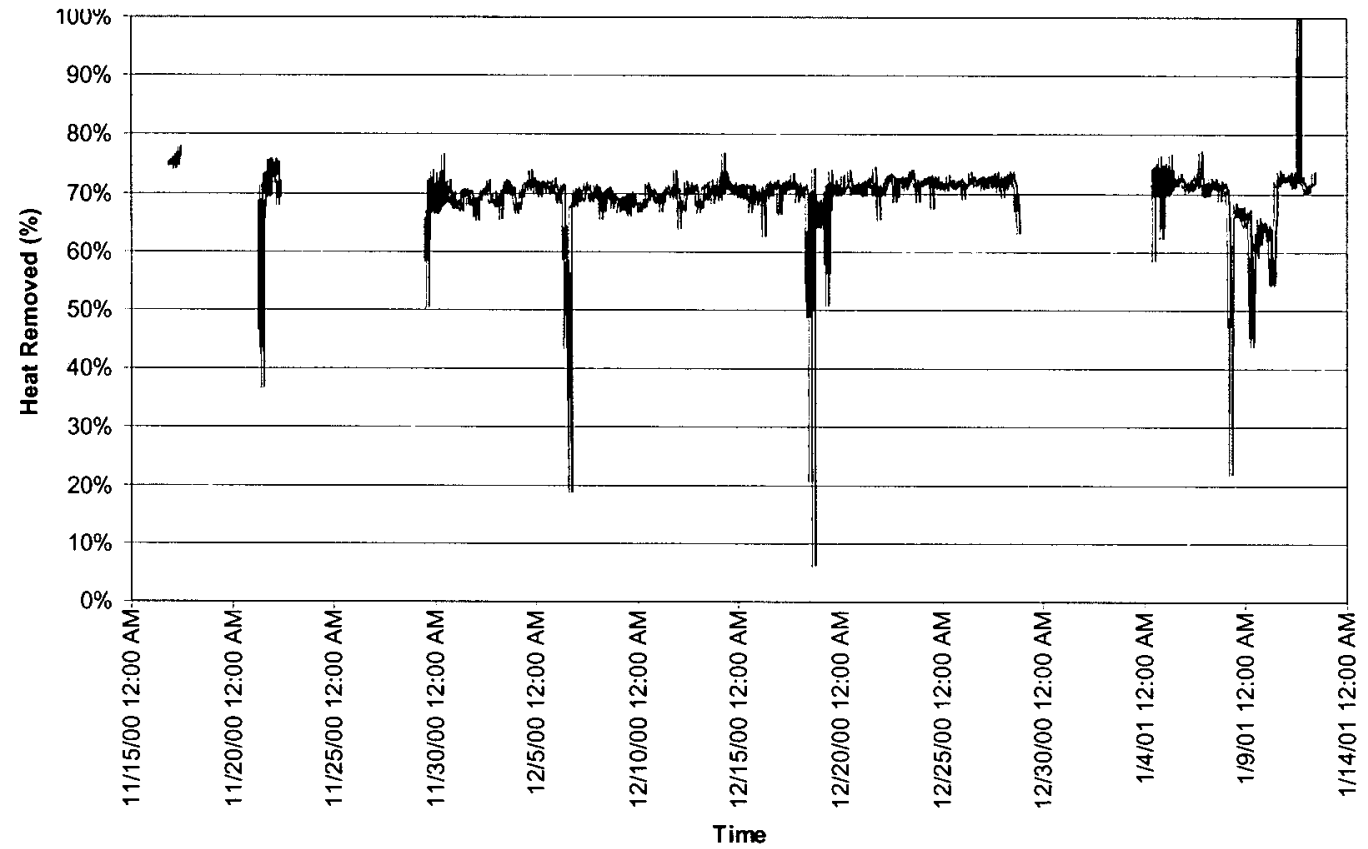

Source: Lowry 2001c, p. 65; DTN\#MO0109EBSCT3HD.008.

Figure 23. Column Test 3 Percent Heat Removal 


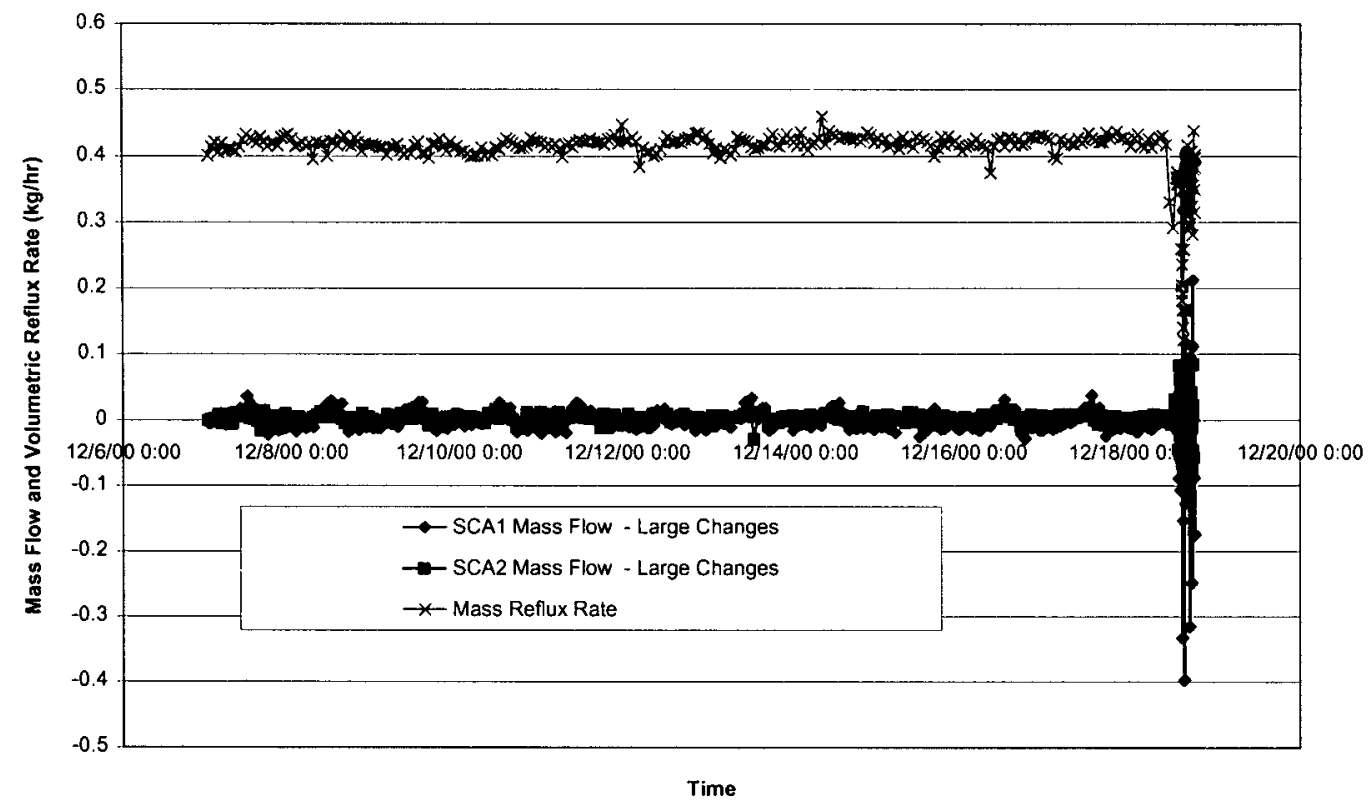

Source: Lowry 2001c, p. 66; DTN\#MO0109EBSCT3HD.008.

Figure 24. Column Water Mass Flow Rates and Estimated Mass Reflux Rate 


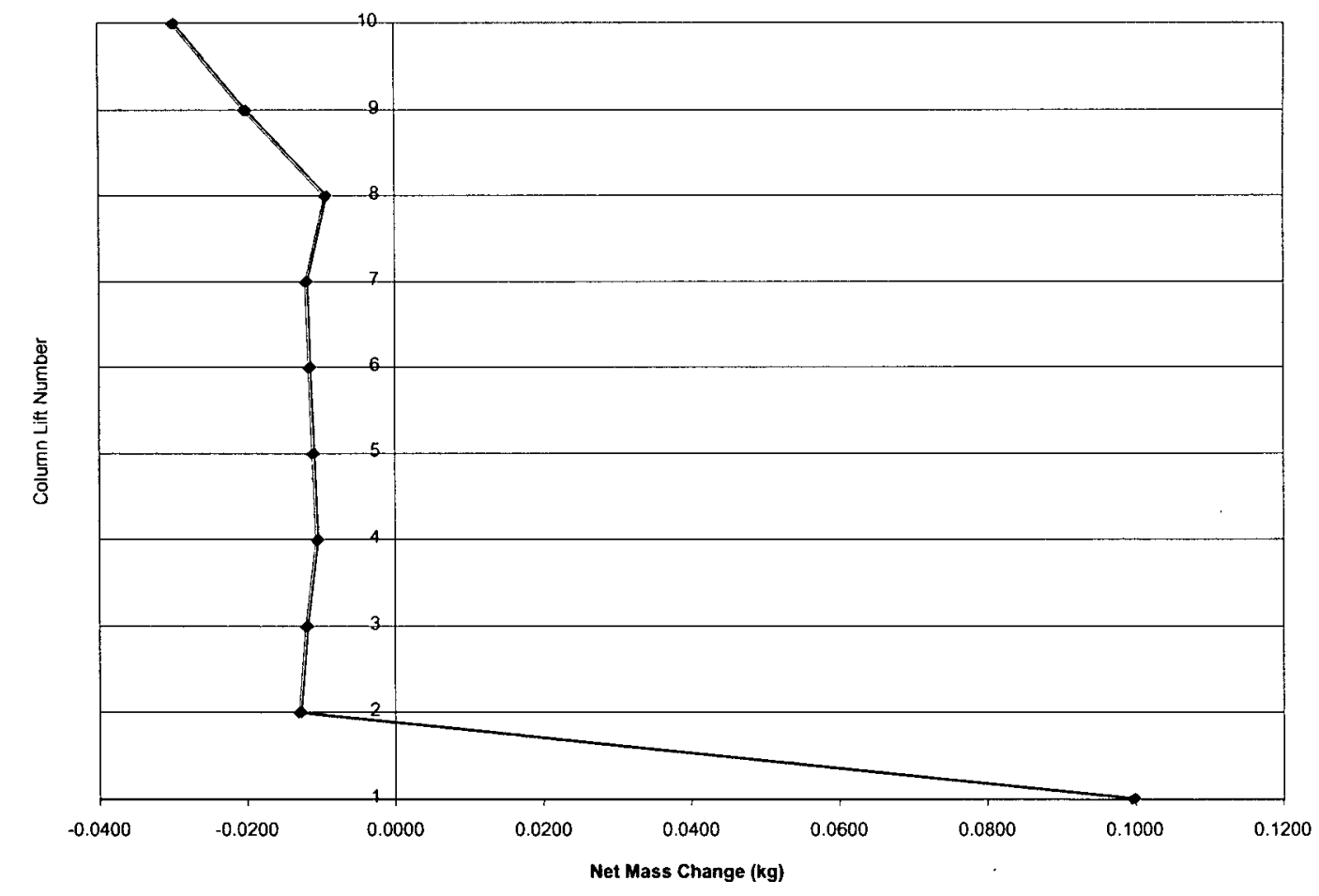

Source: Lowry 2001c, p. 66.

Figure 25. Net Change in Lift Masses 


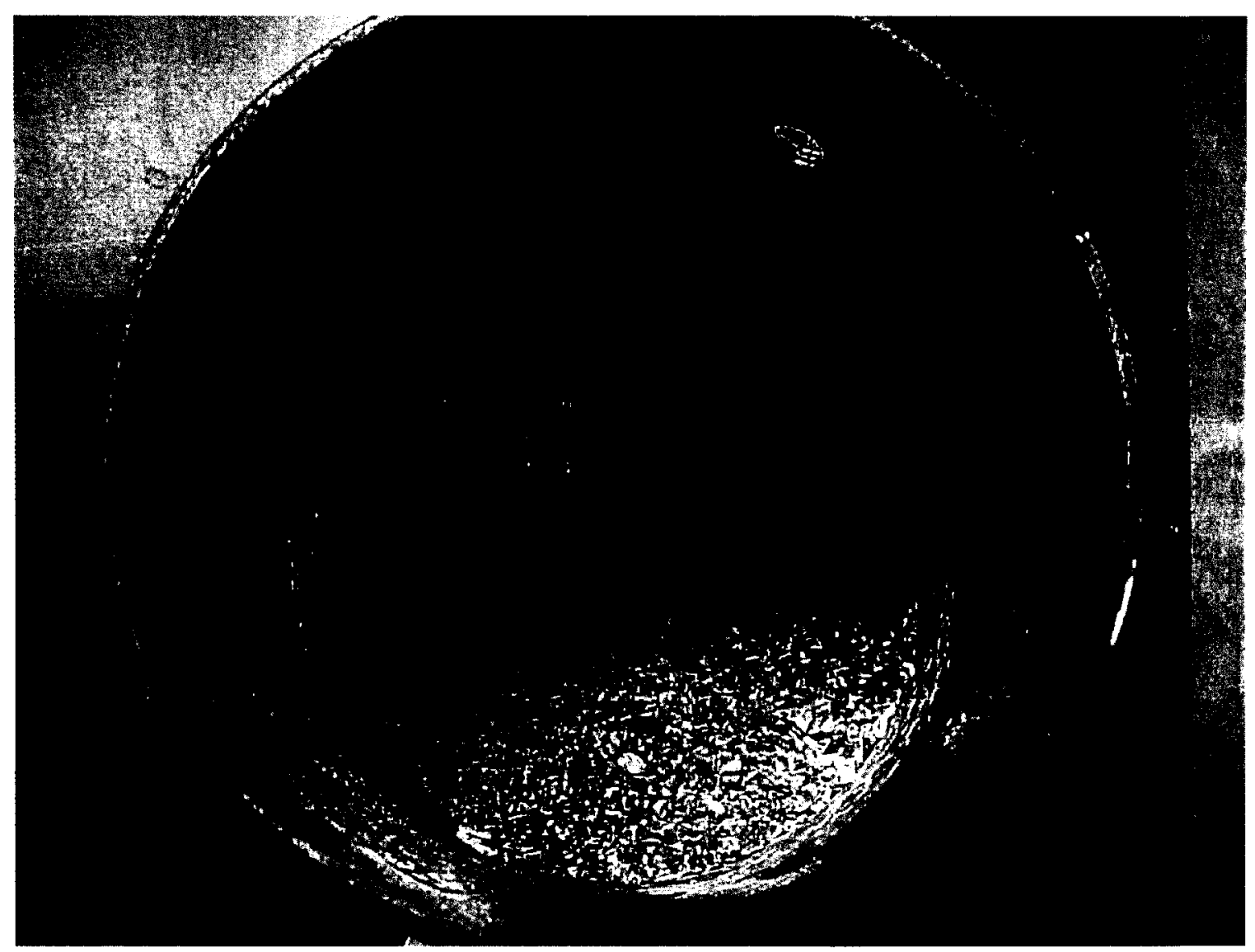

Source: Lowry 2001c, p. 49.

Figure 26. Column Bottom with Cemented Tuff 


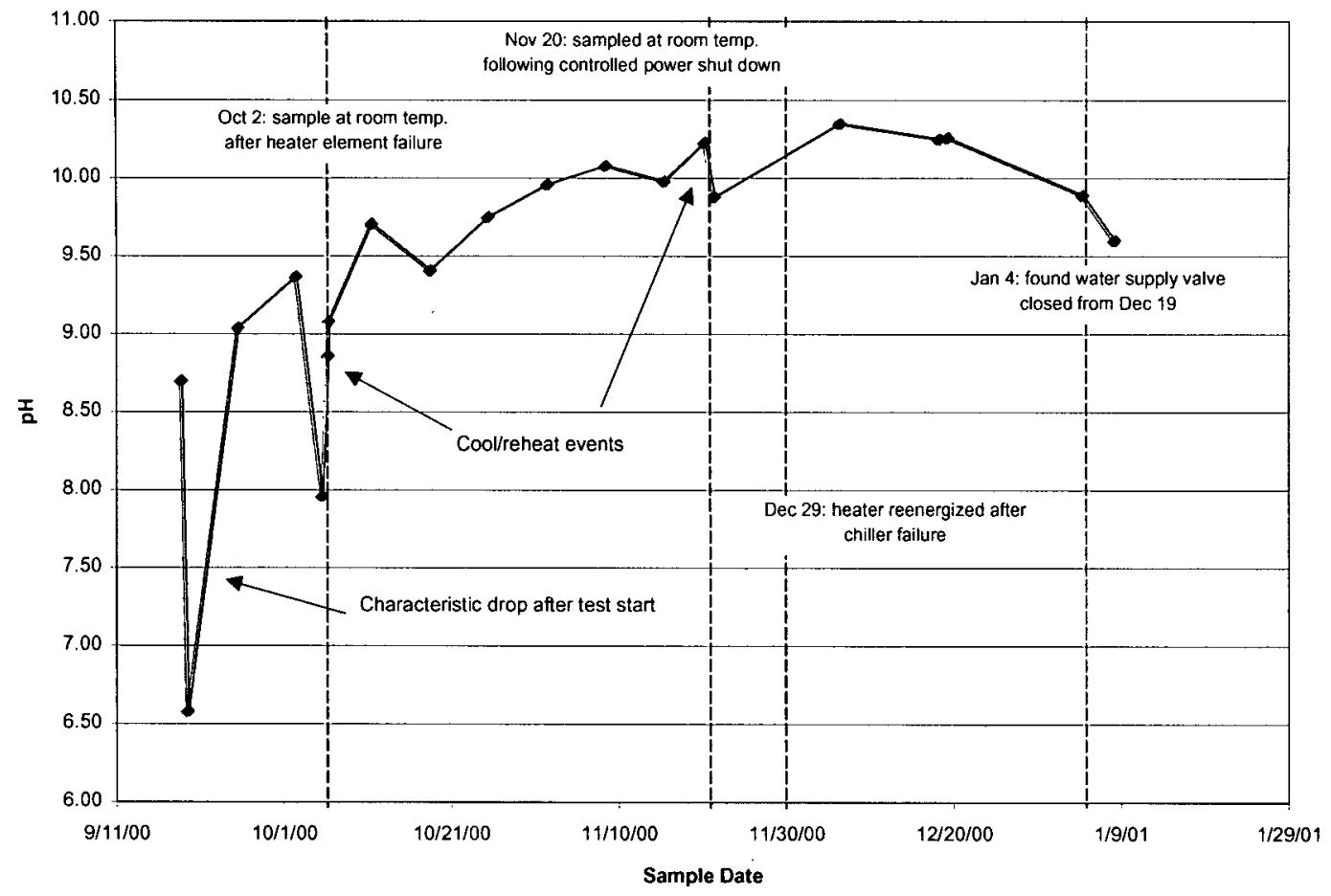

Source: Lowry 2001c, p. 67; DTN\#MO0106EBSCT3PH.005; DTN\#MO0106EBSCT3PH.006.

Figure 27. Column Solution pH Correlated with Process Events 


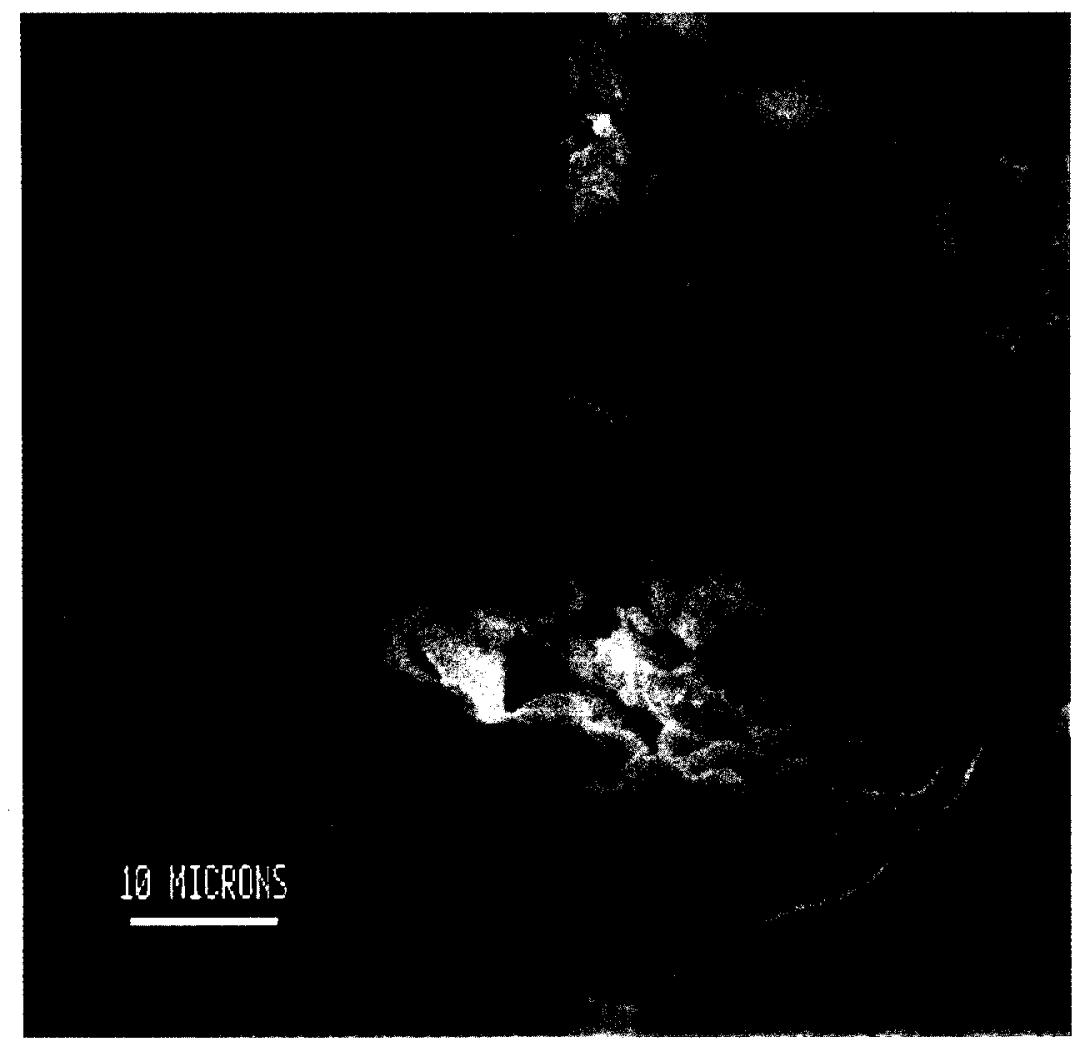

Source: DTN\#LA0108SL831225.001; Lowry 2001c, p. 63.

Figure 28. Secondary-Electron Image of Amorphous Silica Deposited in Ball-Bearing Layer Near Base of Column 


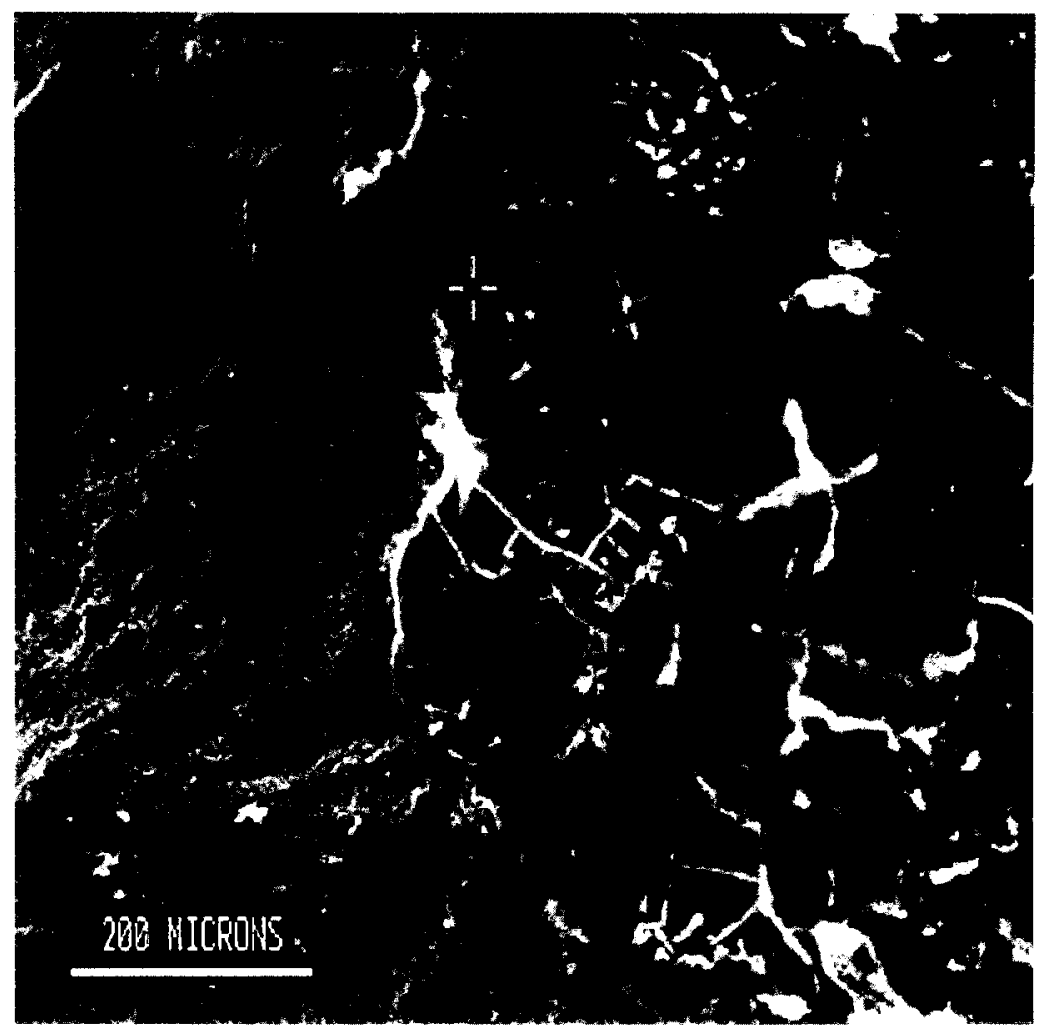

Source: DTN\#LA0108SL831225.001; Lowry 2001c, p. 68.

Figure 29. Secondary-Electron Image of Vitreous Amorphous Silica Coating on Crushed-Tuff Particle 
ATTACHMENT I

COLUMN TEST 3 CHRONOLOGY 
TABLE I.1 COLUMN TEST 3 CHRONOLOGY

\begin{tabular}{|c|c|c|c|c|}
\hline Date & $\begin{array}{l}\text { Time } \\
\text { (Pacific } \\
\text { Standard) }\end{array}$ & Event & Comments & $\begin{array}{l}\text { Cum. heated } \\
\text { operation (hrs) }\end{array}$ \\
\hline $5 / 10 / 00$ & & $\begin{array}{l}\text { Column filled with crushed } \\
\text { tuff. }\end{array}$ & SPC 562011 & \\
\hline $5 / 10 / 00$ & & $\begin{array}{ll}\text { Air } & \text { permeability } \\
\text { measurement performed. }\end{array}$ & & \\
\hline $7 / 5 / 00$ & & $\begin{array}{l}\text { Line conditioner installed on } \\
\text { chiller. }\end{array}$ & & \\
\hline $9 / 18 / 00$ & 16:35 & $\begin{array}{l}\text { Column heater energized to } \\
\text { nominal } 400 \text { watts. }\end{array}$ & CT3 start date & 0 \\
\hline 9/18/00 & $20: 30$ & $\begin{array}{l}60 \mathrm{cc} \text { liquid sample taken } \\
\text { from saturated zone for } \\
\text { cation, anion, and pH } \\
\text { analysis. } 60 \mathrm{cc} \text { liquid sample } \\
\text { taken from supply water } \\
\text { reservoir. }\end{array}$ & & \\
\hline $9 / 19 / 00$ & & $\begin{array}{l}\text { Insulation blanket installed. } \\
\text { Gas samples collected. }\end{array}$ & & \\
\hline $9 / 19 / 00$ & $15: 20$ & $\begin{array}{l}60 \mathrm{cc} \text { liquid sample taken } \\
\text { from saturated zone for } \\
\text { cation, anion, and pH } \\
\text { analysis. } 60 \mathrm{cc} \text { liquid sample } \\
\text { taken from supply water } \\
\text { reservoir. }\end{array}$ & & \\
\hline $9 / 19 / 00$ & $10: 56$ & RTD01 failed. & $\begin{array}{l}\text { Replaced with } \\
\text { RTD04. }\end{array}$ & \\
\hline $9 / 20 / 00$ & & Gas samples collected. & & \\
\hline $9 / 25 / 00$ & & $\begin{array}{l}\text { Preheat cylinder leak repair. } \\
\text { Gas samples collected. }\end{array}$ & & \\
\hline $9 / 25 / 00$ & $15: 40$ & $\begin{array}{l}60 \mathrm{cc} \text { liquid sample taken } \\
\text { from saturated zone for } \\
\text { cation, anion, and } \mathrm{pH} \\
\text { analysis. }\end{array}$ & & \\
\hline $9 / 26 / 00$ & 07:02 & $\begin{array}{l}\text { DAS offline - no data logged } \\
\text { from this time until } 9 / 27 / 00 \\
00: 02 \text {. }\end{array}$ & & \\
\hline $9 / 26 / 00$ & $08: 20$ & $\begin{array}{l}\text { Heat input readjusted to } 400 \\
\text { watts }\end{array}$ & & \\
\hline $9 / 26 / 00$ & & Preheat cylinder replaced. & & \\
\hline $9 / 26 / 00$ & 19:21 & RTD04 failed. & $\begin{array}{l}\text { Replaced with } \\
\text { RTD08. }\end{array}$ & \\
\hline 9/26/00 & 19:30 & RTD03 failed. & $\begin{array}{l}\text { Replaced with } \\
\text { RTD06 }\end{array}$ & \\
\hline 9/27/00 & 00:02 & $\begin{array}{l}\text { DAS online }- \text { begin } \\
\text { collecting data. }\end{array}$ & & \\
\hline
\end{tabular}


TABLE I.1 COLUMN TEST 3 CHRONOLOGY (CONTINUED)

\begin{tabular}{|c|c|c|c|c|}
\hline Date & $\begin{array}{l}\text { Time } \\
\text { (Pacific } \\
\text { Standard) }\end{array}$ & Event & Comments & $\begin{array}{l}\text { Cum. heated } \\
\text { operation (hrs) }\end{array}$ \\
\hline $9 / 27 / 00$ & $09: 20$ & $\begin{array}{l}\text { Heat input adjusted to } 400 \\
\text { watts }\end{array}$ & & \\
\hline $9 / 27 / 00$ & $14: 10$ & $\begin{array}{l}\text { Added DI water to supply } \\
\text { water tank (SCA1) }\end{array}$ & & \\
\hline 9/29/00 & 12:02 & $\begin{array}{l}\text { Heater element malfunction, } \\
\text { column heater de-energized }\end{array}$ & $\begin{array}{l}\text { Failed heater } \\
\text { power } \\
\text { connection }\end{array}$ & 259.5 \\
\hline $10 / 02 / 00$ & 13:25 & $\begin{array}{l}\text { 60cc liquid sample taken } \\
\text { from saturated zone, column } \\
\text { in non-heated condition }\end{array}$ & & \\
\hline $10 / 05 / 00$ & $14: 00$ & Collected gas sample & & \\
\hline $10 / 5 / 00$ & $14: 05$ & $\begin{array}{l}\text { Column heater re-energized } \\
\text { to nominal } 450 \text { watts }\end{array}$ & $\begin{array}{l}\text { New heater } \\
\text { element installed }\end{array}$ & 259.5 \\
\hline $10 / 5 / 00$ & 17:17 & $\begin{array}{l}\text { 60cc liquid sample collected } \\
\text { from supply water tank }\end{array}$ & & \\
\hline
\end{tabular}

\begin{tabular}{|c|c|c|c|c|}
\hline $10 / 5 / 00$ & $17: 50$ & $\begin{array}{l}120 \text { cc liquid sample taken } \\
\text { from saturated zone for } \\
\text { cation, anion, and pH } \\
\text { analysis. }\end{array}$ & & \\
\hline $10 / 6 / 00$ & & $\begin{array}{l}\text { Increasing SCA1 weight and } \\
\text { biological matter found in } \\
\text { supply water tank. }\end{array}$ & $\begin{array}{lr}\text { Filter system } \\
\text { installed } & \text { in } \\
\text { supply water } \\
\text { tank to filter out } \\
\text { biological matter. }\end{array}$ & \\
\hline $10 / 6 / 00$ & $10: 00$ & $\begin{array}{l}30 \text { cc liquid sample taken } \\
\text { from saturated zone for } \mathrm{pH} \\
\text { analysis }\end{array}$ & & \\
\hline $10 / 9 / 00$ & $00: 17$ & $\begin{array}{l}\text { Chiller malfunction, column } \\
\text { heater de-energized }\end{array}$ & $\begin{array}{ll}\text { Bad } & \text { fuse } \\
\text { connection } & \\
\end{array}$ & 341.5 \\
\hline $10 / 9 / 00$ & 19:48 & $\begin{array}{l}\text { Chiller repaired, column } \\
\text { heater re-energized to } \\
\text { nominal } 475 \text { watts }\end{array}$ & $\begin{array}{l}\text { Heater reached } \\
475 \text { watts } \\
\text { naturally, did not } \\
\text { adjust power } \\
\text { input, only re- } \\
\text { energized it }\end{array}$ & 341.5 \\
\hline $10 / 10 / 00$ & $11: 33$ & $\begin{array}{l}\text { Drained, rinsed, and } \\
\text { replaced DI water in supply } \\
\text { water tank. }\end{array}$ & $\begin{array}{l}\text { Completed at } \\
11: 33 \text {. }\end{array}$ & \\
\hline $10 / 11 / 00$ & $14: 30$ & $\begin{array}{l}60 \mathrm{cc} \text { liquid sample taken } \\
\text { from saturated zone for } \\
\text { cation, anion, and pH } \\
\text { analysis. }\end{array}$ & & \\
\hline
\end{tabular}


TABLE I.1 COLUMN TEST 3 CHRONOLOGY (CONTINUED)

\begin{tabular}{|c|c|c|c|c|}
\hline Date & $\begin{array}{l}\text { Time } \\
\text { (Pacific } \\
\text { Standard) }\end{array}$ & Event & Comments & $\begin{array}{l}\text { Cum. heated } \\
\text { operation (hrs) }\end{array}$ \\
\hline $10 / 11 / 00$ & $16: 00$ & Collected gas sample. & & \\
\hline $10 / 18 / 00$ & $12: 10$ & Collected gas sample. & & \\
\hline $10 / 18 / 00$ & 15:09 & $\begin{array}{l}60 \mathrm{cc} \text { liquid sample taken } \\
\text { from saturated zone for } \\
\text { cation, anion, and } \mathrm{pH} \\
\text { analysis. }\end{array}$ & & \\
\hline $10 / 23 / 00$ & 12:02 & Heater power interrupted. & $\begin{array}{lr}\text { Due to } & \text { rough } \\
\text { handling } & \text { of } \\
\text { latching } & \text { relay } \\
\text { box. } & \\
\end{array}$ & 669.9 \\
\hline $10 / 23 / 00$ & $14: 20$ & $\begin{array}{l}\text { Column heater re-energized } \\
\text { to nominal } 400 \text { Watts. }\end{array}$ & $\begin{array}{l}\text { Fuse replaced in } \\
\text { temperature } \\
\text { controller. }\end{array}$ & 669.9 \\
\hline $10 / 25 / 00$ & $09: 42$ & Gas sample collected. & & \\
\hline $10 / 25 / 00$ & $12: 48$ & $\begin{array}{l}60 \mathrm{cc} \text { liquid sample taken } \\
\text { from saturated zone for } \\
\text { cation, anion, and } \mathrm{pH} \\
\text { analysis. }\end{array}$ & & \\
\hline $11 / 1 / 00$ & $13: 40$ & $\begin{array}{l}60 \mathrm{cc} \text { liquid sample taken } \\
\text { from saturated zone for } \\
\text { cation, anion, and } \mathrm{pH} \\
\text { analysis. }\end{array}$ & & \\
\hline $11 / 1 / 00$ & $14: 50$ & $\begin{array}{l}60 \mathrm{cc} \text { liquid sample taken } \\
\text { from saturated zone for } \\
\text { cation, anion, and } \mathrm{pH} \\
\text { analysis. }\end{array}$ & & \\
\hline $11 / 8 / 00$ & $12: 57$ & $\begin{array}{l}60 \mathrm{cc} \text { liquid sample taken } \\
\text { from saturated zone for } \\
\text { cation, anion, and } \mathrm{pH} \\
\text { anaysis. }\end{array}$ & & \\
\hline $11 / 15 / 00$ & $11: 35$ & Collected gas sample. & & \\
\hline
\end{tabular}

\begin{tabular}{|l|l|l|l|l|}
\hline $11 / 16 / 00$ & $12: 00$ & $\begin{array}{l}\text { Disconnected CT1-FLO1 to } \\
\text { check calibration }\end{array}$ & & \\
& & & & \\
\hline
\end{tabular}


TABLE I.1 COLUMN TEST 3 CHRONOLOGY (CONTINUED)

\begin{tabular}{|c|c|c|c|c|}
\hline Date & $\begin{array}{l}\text { Time } \\
\text { (Pacific } \\
\text { Standard) }\end{array}$ & Event & Comments & $\begin{array}{l}\text { Cum. heated } \\
\text { operation (hrs) }\end{array}$ \\
\hline $11 / 16 / 00$ & $11: 00$ & Heater power interrupted. & $\begin{array}{l}\text { Cooling cap } \\
\text { temperature rose } \\
\text { while removing } \\
\text { cooling water } \\
\text { flow - meter for } \\
\text { calibration } \\
\text { check. Did not } \\
\text { immediately } \\
\text { notice it } \\
\text { interrupted } \\
\text { heater power. }\end{array}$ & 1242.6 \\
\hline $11 / 16 / 00$ & $13: 00$ & $\begin{array}{l}\text { Column heater re-energized } \\
\text { to nominal } 400 \text { Watts. }\end{array}$ & $\begin{array}{l}\text { Realized heater } \\
\text { was off and } \\
\text { reinitiated power. }\end{array}$ & 1242.6 \\
\hline $11 / 16 / 00$ & $21: 15$ & $\begin{array}{l}\text { Verified correct calibration of } \\
\text { CT1-FLO1 and discovered } \\
\text { DAS was responsible for } \\
\text { erroneous flow data. }\end{array}$ & $\begin{array}{l}\text { Adjusted DAS } \\
\text { and reconnected } \\
\text { flowmeter - flow } \\
\text { data accurate } \\
\text { now. }\end{array}$ & \\
\hline $11 / 17 / 00$ & $12: 00$ & Heater power interrupted. & $\begin{array}{l}\text { Planned } \\
\text { weekend } \\
\text { shutdown to } \\
\text { accommodate } \\
\text { planned power } \\
\text { outages. }\end{array}$ & 1265.6 \\
\hline $11 / 20 / 00$ & 08:43 & Gas sample collected. & & \\
\hline $11 / 20 / 00$ & $09: 25$ & $\begin{array}{l}120 \mathrm{cc} \text { liquid sample taken } \\
\text { from saturated zone for } \\
\text { cation, anion, and } \mathrm{pH} \\
\text { anaysis. }\end{array}$ & & \\
\hline $11 / 20 / 00$ & $11: 02$ & $\begin{array}{l}\text { Column heater re-energized } \\
\text { to nominal } 400 \text { Watts. }\end{array}$ & $\begin{array}{l}\text { Restart after } \\
\text { planned } \\
\text { interruption. } \\
\end{array}$ & 1265.6 \\
\hline $11 / 20 / 00$ & $18: 37$ & Heater power interrupted. & $\begin{array}{l}\text { Chiller } \\
\text { malfunction. }\end{array}$ & 1273.1 \\
\hline $11 / 21 / 00$ & $08: 17$ & $\begin{array}{l}\text { Column heater re-energized } \\
\text { to nominal } 400 \text { watts. }\end{array}$ & $\begin{array}{l}\text { Fuse replaced in } \\
\text { chiller. }\end{array}$ & 1273.1 \\
\hline $11 / 21 / 00$ & $14: 30$ & $\begin{array}{l}120 \mathrm{cc} \text { liquid sample taken } \\
\text { from saturated zone for } \\
\text { cation, anion, and } \mathrm{pH} \\
\text { anaysis. }\end{array}$ & & \\
\hline $11 / 22 / 00$ & $11: 07$ & Heater power interrupted. & $\begin{array}{l}\text { Chiller } \\
\text { malfunction. }\end{array}$ & 1300.0 \\
\hline
\end{tabular}


TABLE I.1 COLUMN TEST 3 CHRONOLOGY (CONTINUED)

\begin{tabular}{|l|l|l|l|l|}
\hline Date & $\begin{array}{l}\text { Time } \\
\text { (Pacific } \\
\text { Standard) }\end{array}$ & Event & Comments & $\begin{array}{l}\text { Cum. heated } \\
\text { operation (hrs) }\end{array}$ \\
\hline $11 / 27 / 00$ & $14: 02$ & $\begin{array}{l}\text { Column heater re-energized } \\
\text { to nominal 400 watts. }\end{array}$ & $\begin{array}{l}\text { Fuse replaced in } \\
\text { chiller. }\end{array}$ & 1300.0 \\
\hline $11 / 27 / 00$ & $18: 02$ & Heater power interrupted. & $\begin{array}{l}\text { Chiller } \\
\text { malfunction. }\end{array}$ & 1304.0 \\
\hline $11 / 29 / 00$ & $13: 37$ & $\begin{array}{l}\text { Column heater re-energized } \\
\text { to nominal 400 watts. }\end{array}$ & $\begin{array}{l}\text { Circuit board } \\
\text { replaced in } \\
\text { chiller. }\end{array}$ & 1304.0 \\
\hline $12 / 6 / 00$ & $10: 25$ & Gas sample collected. & $\begin{array}{l}\text { Begin using } \\
\text { gravity water trap } \\
\text { during gas } \\
\text { collection. } \\
\text { Volume of water } \\
\text { collected is } \\
\text { unkown. }\end{array}$ & \\
\hline $12 / 6 / 00$ & $12: 30$ & $\begin{array}{l}60 c c \text { liquid sample taken } \\
\text { from saturated zone for } \\
\text { cation, anion, and pH } \\
\text { analysis. }\end{array}$ & \\
\hline
\end{tabular}

\begin{tabular}{|c|c|c|c|c|}
\hline $12 / 8 / 00$ & $12: 00$ & Time stamp & & 1518.4 \\
\hline $12 / 18 / 00$ & 09:20 & $\begin{array}{l}70 \mathrm{cc} \text { liquid sample taken } \\
\text { from saturated zone for } \\
\text { cation, anion, and pH } \\
\text { analysis. }\end{array}$ & & \\
\hline $12 / 18 / 00$ & $16: 26$ & $\begin{array}{l}\text { Adjusted air flow rate to } \\
20 \mathrm{cc} / \mathrm{min} \text {. }\end{array}$ & $\begin{array}{l}\text { Begin } \\
\text { overpressure } \\
\text { test, see pages } \\
\text { 139-141 Sci. } \\
\text { Notebook SN- } \\
\text { M\&O-SCI-016- } \\
\text { V2. }\end{array}$ & \\
\hline $12 / 18 / 00$ & $17: 04$ & $\begin{array}{l}\text { Adjusted air flow rate to } \\
\text { 40cc/min. }\end{array}$ & & \\
\hline $12 / 18 / 00$ & $17: 37$ & $\begin{array}{l}\text { Adjusted air flow rate to } \\
60 \mathrm{cc} / \mathrm{min} \text {, and maintained } \\
\text { this flow overniaht }\end{array}$ & & \\
\hline $12 / 18 / 00$ & $18: 30$ & Heater power interrupted. & $\begin{array}{lr}\text { Inspection } & \text { of } \\
\text { latching } & \text { relay } \\
\text { system. }\end{array}$ & 1764.9 \\
\hline $12 / 18 / 00$ & $18: 45$ & $\begin{array}{l}\text { Column heater re-energized } \\
\text { to nominal } 400 \text { watts. }\end{array}$ & $\begin{array}{l}\text { Completed } \\
\text { above inspection }\end{array}$ & 1764.9 \\
\hline $12 / 19 / 00$ & $09: 35$ & $\begin{array}{l}80 \mathrm{cc} \text { liquid sample taken } \\
\text { from saturated zone for } \\
\text { cation, anion, and } \mathrm{pH} \\
\text { analysis. }\end{array}$ & & \\
\hline
\end{tabular}


TABLE I.1 COLUMN TEST 3 CHRONOLOGY (CONTINUED)

\begin{tabular}{|c|c|c|c|c|}
\hline Date & $\begin{array}{l}\text { Time } \\
\text { (Pacific } \\
\text { Standard) }\end{array}$ & Event & Comments & $\begin{array}{l}\text { Cum. heated } \\
\text { operation (hrs) }\end{array}$ \\
\hline $12 / 19 / 00$ & $09: 40$ & Gas sample collected & $\begin{array}{lr}\text { Approx. } 100 \mathrm{cc} \\
\text { water collected } \\
\text { in trap. }\end{array}$ & \\
\hline $12 / 19 / 00$ & $11: 54$ & $\begin{array}{l}\text { Returned air flow rate to } \\
\text { nominal } 16 \mathrm{cc} / \mathrm{min} \text {. }\end{array}$ & $\begin{array}{l}\text { End } \\
\text { overpressure } \\
\text { test. }\end{array}$ & \\
\hline $12 / 22 / 00$ & $12: 00$ & Time Stamp & & 1854.1 \\
\hline $1 / 4 / 01$ & $08: 30$ & $\begin{array}{l}\text { During sampling event, } \\
\text { found sampling valve closed. } \\
\text { Column water was not being } \\
\text { replenished and the level } \\
\text { was well below sampling port } \\
\text { \#1. }\end{array}$ & $\begin{array}{l}\text { Sampling valve } \\
\text { was opened to } \\
\text { allow column } \\
\text { water to refill } \\
\text { before drawing a } \\
\text { liquid sample. }\end{array}$ & \\
\hline $1 / 4 / 01$ & 13:15 & $\begin{array}{l}60 \mathrm{cc} \text { liquid sample taken } \\
\text { from saturated zone for } \\
\text { cation, anion, and } \mathrm{pH} \\
\text { analysis. }\end{array}$ & & \\
\hline $1 / 5 / 01$ & $10: 26$ & $\begin{array}{l}\text { Column bottom temperature } \\
\text { (Channel 4) was rising near } \\
\text { the set point of } 205{ }^{\circ} \mathrm{C} \text {. } \\
\text { Changed setting to } 210^{\circ} \mathrm{C} \text { to } \\
\text { maintain heat energy } \\
\text { through cooling cap test. }\end{array}$ & & \\
\hline $1 / 8 / 01$ & $05: 13$ & Gas sample collected. & $\begin{array}{lr}\text { Approx. } & 440 \mathrm{cc} \\
\text { water } & \text { collected } \\
\text { in trap } & \\
\end{array}$ & \\
\hline $1 / 8 / 01$ & $08: 30$ & $\begin{array}{l}60 \mathrm{cc} \text { liquid sample taken } \\
\text { from saturated zone for } \\
\text { cation, anion, and } \mathrm{pH} \\
\text { analysis. }\end{array}$ & & \\
\hline 1/8/01 & $09: 47$ & $\begin{array}{l}\text { Adjusted chiller } \\
\text { temperature to } 25^{\circ} \mathrm{C} \text {. }\end{array}$ & $\begin{array}{l}\text { Begin cooling } \\
\text { cap temperature } \\
\text { test, see pages } \\
148-152 \text {. }\end{array}$ & \\
\hline $1 / 9 / 01$ & 07:04 & Gas sample collected. & $\begin{array}{lr}\text { Approx. } 175 \mathrm{cc} \\
\text { water collected } \\
\text { in trap }\end{array}$ & \\
\hline $1 / 9 / 00$ & $11: 19$ & $\begin{array}{l}\text { Adjusted chiller } \\
\text { temperature to } 40^{\circ} \mathrm{C} \text {. }\end{array}$ & & \\
\hline
\end{tabular}

\begin{tabular}{|l|l|l|l|l|}
\hline $1 / 10 / 01$ & $06: 57$ & Gas sample collected. & $\begin{array}{l}\text { Approx. 225cc } \\
\text { water collected } \\
\text { in trap }\end{array}$ & \\
\hline $1 / 10 / 01$ & $12: 59$ & $\begin{array}{l}\text { Adj. chiller bath temperature } \\
\text { to nominal } 10^{\circ} \mathrm{C} .\end{array}$ & $\begin{array}{l}\text { End cooling cap } \\
\text { temperature test. }\end{array}$ & \\
\hline Date & Time & Event & Comments & Cum. heated \\
\hline
\end{tabular}


TABLE I. 1 COLUMN TEST 3 CHRONOLOGY (CONTINUED)

\begin{tabular}{|l|l|l|l|l|}
\hline & $\begin{array}{l}\text { (Pacific } \\
\text { Standard) }\end{array}$ & & & operation (hrs) \\
\hline $1 / 12 / 01$ & $11: 40$ & $\begin{array}{l}\text { Column heater power turned } \\
\text { off. }\end{array}$ & $\begin{array}{l}\text { Channel } \\
\text { temperature at } \\
108^{\circ} \mathrm{C} .\end{array}$ & 2357.8 \\
\hline $1 / 16 / 01$ & $08: 47$ & $\begin{array}{l}120 \mathrm{cc} \text { liquid sample taken } \\
\text { from saturated zone for } \\
\text { cation, anion, and pH } \\
\text { analysis. }\end{array}$ & \\
\hline $1 / 16 / 01$ & $09: 00$ & $\begin{array}{l}\text { Turned of chiller and all } \\
\text { external devices. Drained } \\
\text { column water. }\end{array}$ & $\begin{array}{l}\text { Collected } \\
684.4 \mathrm{cc} \text { water } \\
\text { from column. }\end{array}$ & \\
\hline $1 / 16 / 01$ & $12: 15$ & $\begin{array}{l}\text { Start column drying with } \\
\text { ambient air. }\end{array}$ & $\begin{array}{l}\text { Drying air flow } \\
\text { rate } \\
\text { approximately 20 } \\
\text { slpm. }\end{array}$ & \\
\hline $1 / 25 / 01$ & $\begin{array}{l}\text { Before } \\
12: 00\end{array}$ & $\begin{array}{l}\text { Performed post-test air } \\
\text { permeability measurements. }\end{array}$ & \\
\hline $1 / 25 / 01$ & $\begin{array}{l}\text { After } \\
12: 00\end{array}$ & $\begin{array}{l}\text { Unloaded column tuff and } \\
\text { identified lift samples. }\end{array}$ & \\
\hline
\end{tabular}

Source: Lowry 2001c, pp 7-11 
Table 1-2. CT3 Heated Chronology

\begin{tabular}{|l|l|r|r|}
\hline Date and time & EVENT & $\begin{array}{l}\text { Heated delta } \\
\text { time (hrs) }\end{array}$ & $\begin{array}{l}\text { Heated cum. } \\
\text { time (hrs) }\end{array}$ \\
\hline 9/18/00 16:35 & Column heater energized. & 0.0 & 0.0 \\
\hline $9 / 29 / 0012: 02$ & $\begin{array}{l}\text { Heater power interrupted. Heater } \\
\text { element malfunction. }\end{array}$ & 259.5 & 259.5 \\
\hline 10/5/00 14:05 & Heater re-energized to 450 watts. & 0.0 & 259.5 \\
\hline $10 / 9 / 00 ~ 0: 17$ & $\begin{array}{l}\text { Heater power interrupted. Chiller } \\
\text { malfunction. }\end{array}$ & 82.2 & 341.7 \\
\hline $10 / 9 / 0019: 48$ & $\begin{array}{l}\text { lolumn heater re-energized to 475 } \\
\text { Watts. Chiller repaired. }\end{array}$ & 0.0 & 341.7 \\
\hline $10 / 23 / 0012: 02$ & $\begin{array}{l}\text { Heater power interrupted. Rough } \\
\text { handling of latching relay box. }\end{array}$ & 328.2 & 669.9 \\
\hline $10 / 23 / 0014: 20$ & $\begin{array}{l}\text { Heater re-energized to 400 watts. } \\
\text { Fuse replaced in temperature } \\
\text { controller. }\end{array}$ & 0.0 & 669.9 \\
\hline $11 / 16 / 0011: 00$ & $\begin{array}{l}\text { Heater power interrupted. Cooling cap } \\
\text { temp rose while removing cooling } \\
\text { water flow-meter for calibration check. }\end{array}$ & 572.7 & 1242.6 \\
\hline $11 / 16 / 0013: 00$ & $\begin{array}{l}\text { Heater re-energized to 400 watts. } \\
\text { Realized heater was off. }\end{array}$ & \\
\hline $11 / 17 / 0012: 00$ & $\begin{array}{l}\text { Heater power interrupted for planned } \\
\text { power outages. }\end{array}$ & 23.0 & 1265.6 \\
\hline
\end{tabular}

\begin{tabular}{|c|c|c|c|}
\hline 11/20/00 11:02 & Heater re-energized to 400 watts. & 0.0 & 1265.6 \\
\hline $11 / 20 / 0018: 37$ & $\begin{array}{l}\text { Heater power interrupted. Chiller } \\
\text { malfunction. }\end{array}$ & 7.6 & 1273.1 \\
\hline 11/21/00 8:17 & $\begin{array}{l}\text { Heater re-energized to } 400 \text { watts. } \\
\text { Fuse replaced in chiller. }\end{array}$ & 0.0 & 1273.1 \\
\hline 11/22/00 11:07 & $\begin{array}{l}\text { Heater power interrupted. } \\
\text { malfunction. }\end{array}$ & 26.8 & 1300.0 \\
\hline 11/27/00 14:02 & $\begin{array}{l}\text { Heater re-energized to } 400 \text { watts. } \\
\text { Fuse replaced in chiller. }\end{array}$ & 0.0 & 1300.0 \\
\hline 11/27/00 18:02 & $\begin{array}{l}\text { Heater power interrupted. Chiller } \\
\text { malfunction. }\end{array}$ & 4.0 & 1304.0 \\
\hline 11/29/00 13:37 & $\begin{array}{l}\text { Heater re-energized to } 400 \text { watts. } \\
\text { Circuit board replaced in chiller. } \\
\end{array}$ & 0.0 & 1304.0 \\
\hline $12 / 8 / 0012: 00$ & Time stamp & 214.4 & 1518.4 \\
\hline 12/18/00 18:30 & $\begin{array}{l}\text { Heater power interrupted. Inspection } \\
\text { of latching relay system. }\end{array}$ & 246.5 & 1764.9 \\
\hline 12/18/00 18:45 & $\begin{array}{l}\text { Column heater re-energized to } 400 \\
\text { Watts. }\end{array}$ & 0.0 & 1764.9 \\
\hline $12 / 22 / 0012: 00$ & Time stamp. & 89.3 & 1854.1 \\
\hline $1 / 12 / 0111: 40$ & Column heater power turned off & 503.7 & 2357.8 \\
\hline $\begin{array}{r}\text { heated delta } \\
=\end{array}$ & $($ (Time2-Time1)*24 hours & & \\
\hline
\end{tabular}

Source: Lowry 2001c, p. 12 


\section{ATTACHMENT II}

\section{PHOTOS OF CEMENTED TUFF FROM COLUMN TEST 3}

(Source: Lowry 2001c) 


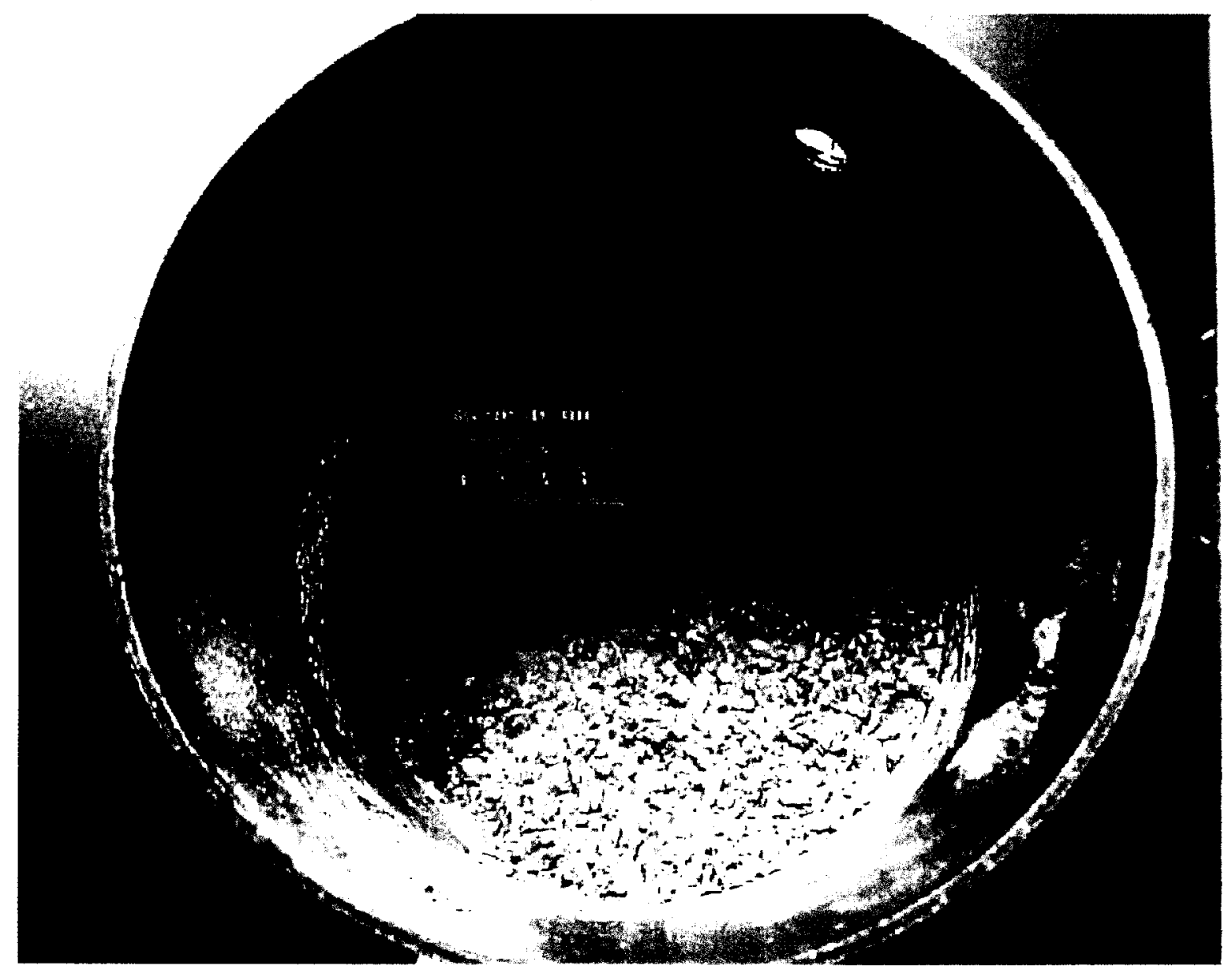

Photo II-1. Column Bottom With Cemented Tuff, Upper Ball Bearing Layer Exposed. 


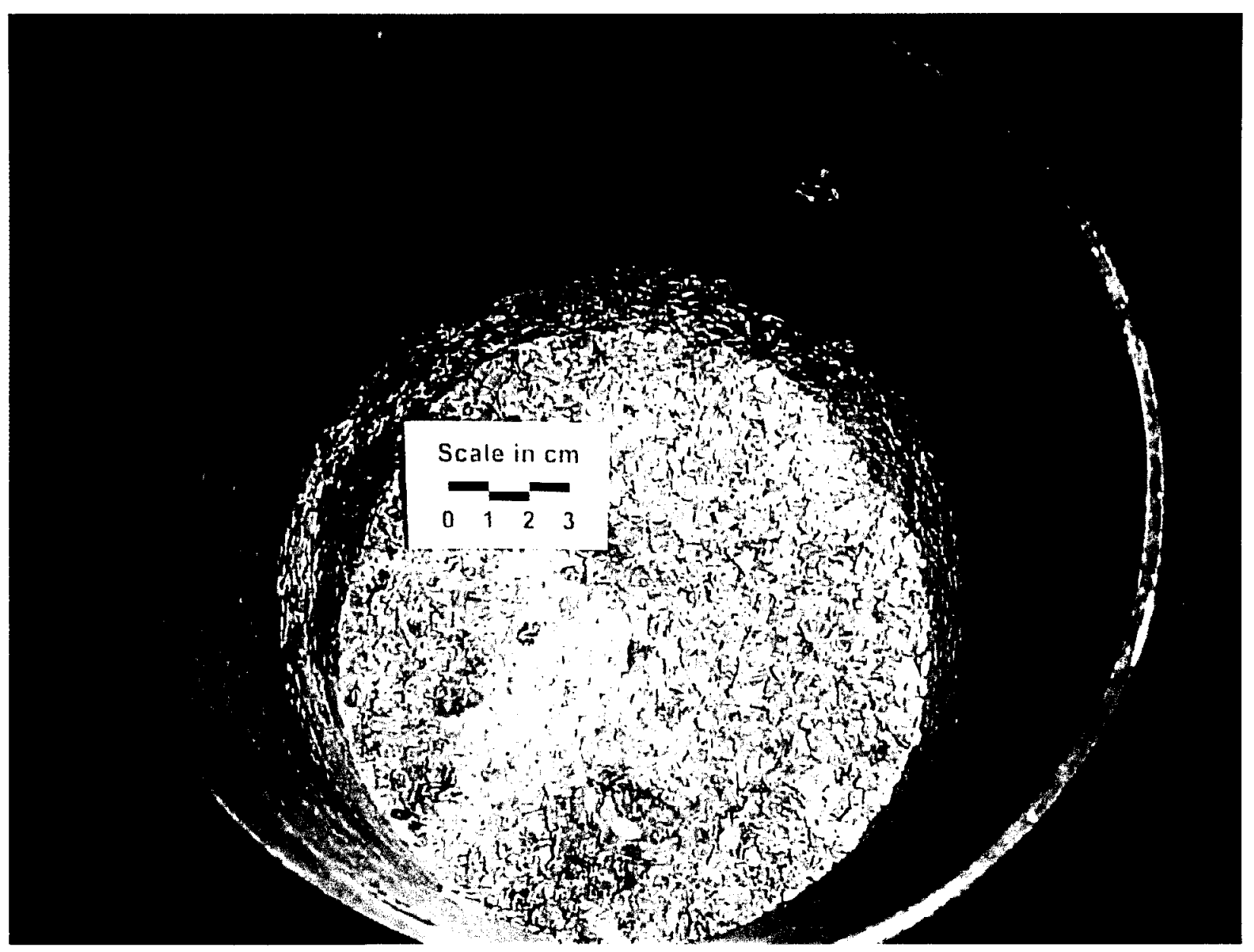

Photo II-2. Column Bottom With Cemented Tuff Above Ball Bearing Layer. 


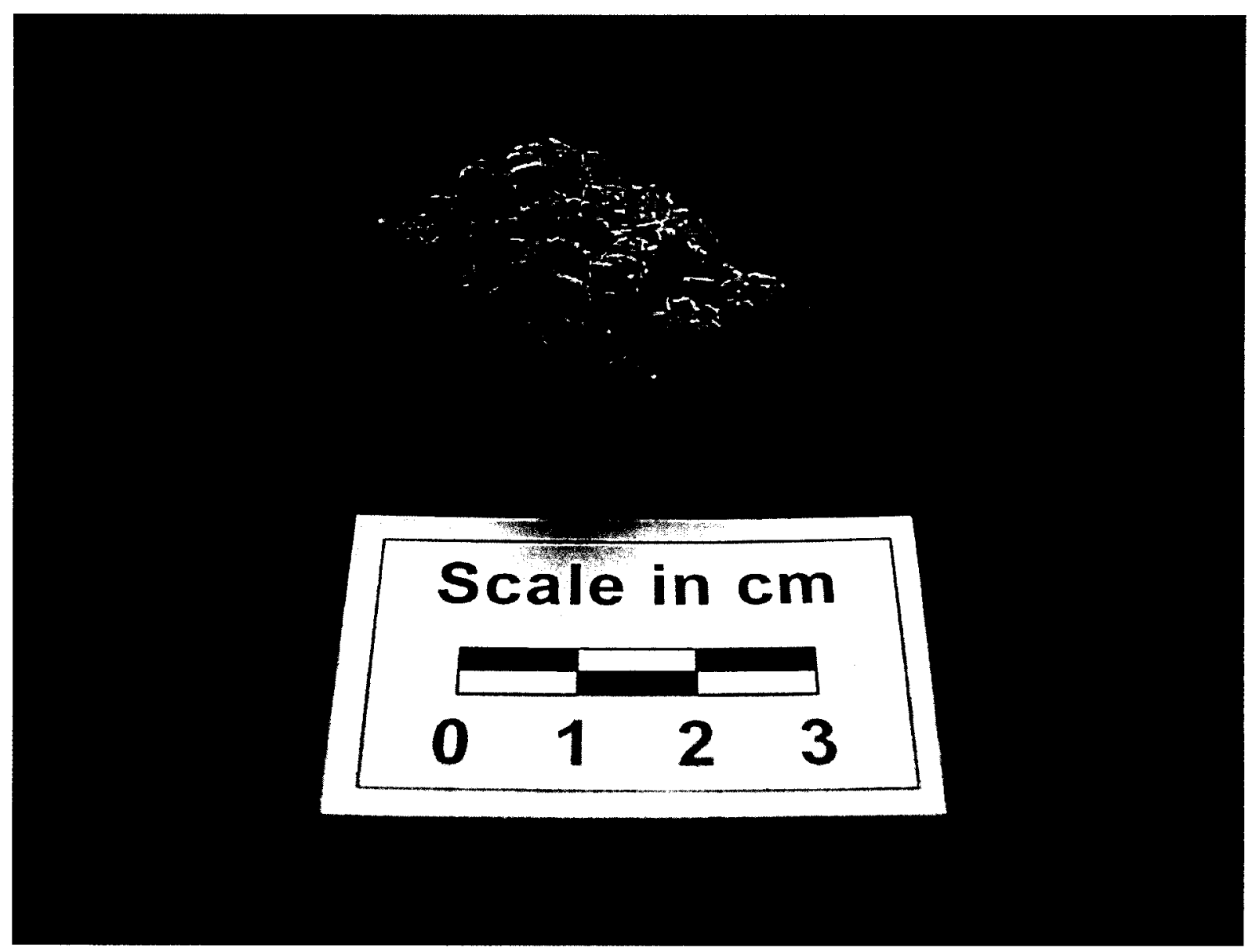

Photo II-3. Cemented Rock Mass From Lift 1. 


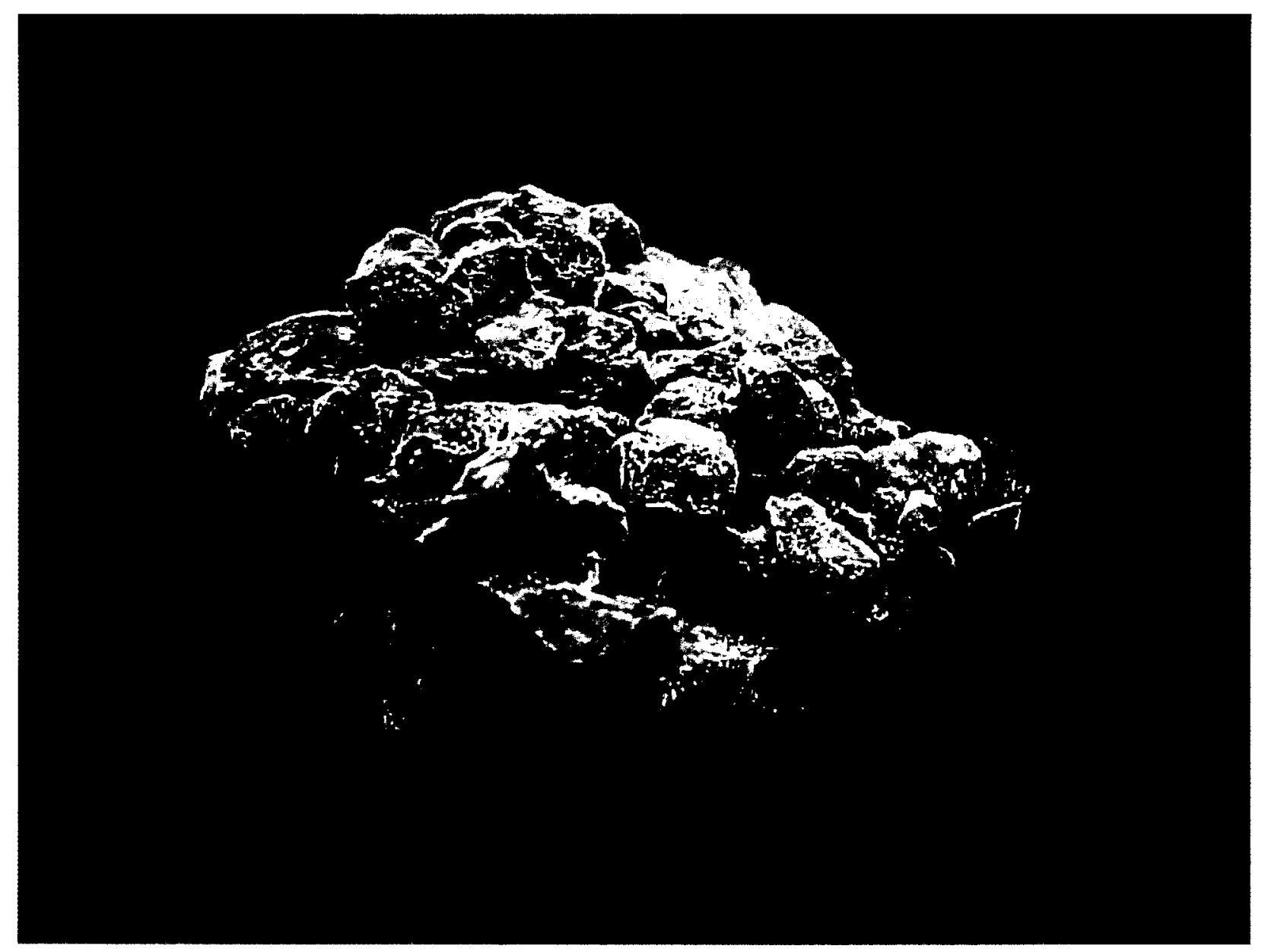

Photo II-4. Close-Up of Cemented Rock Mass From Lift 1. 


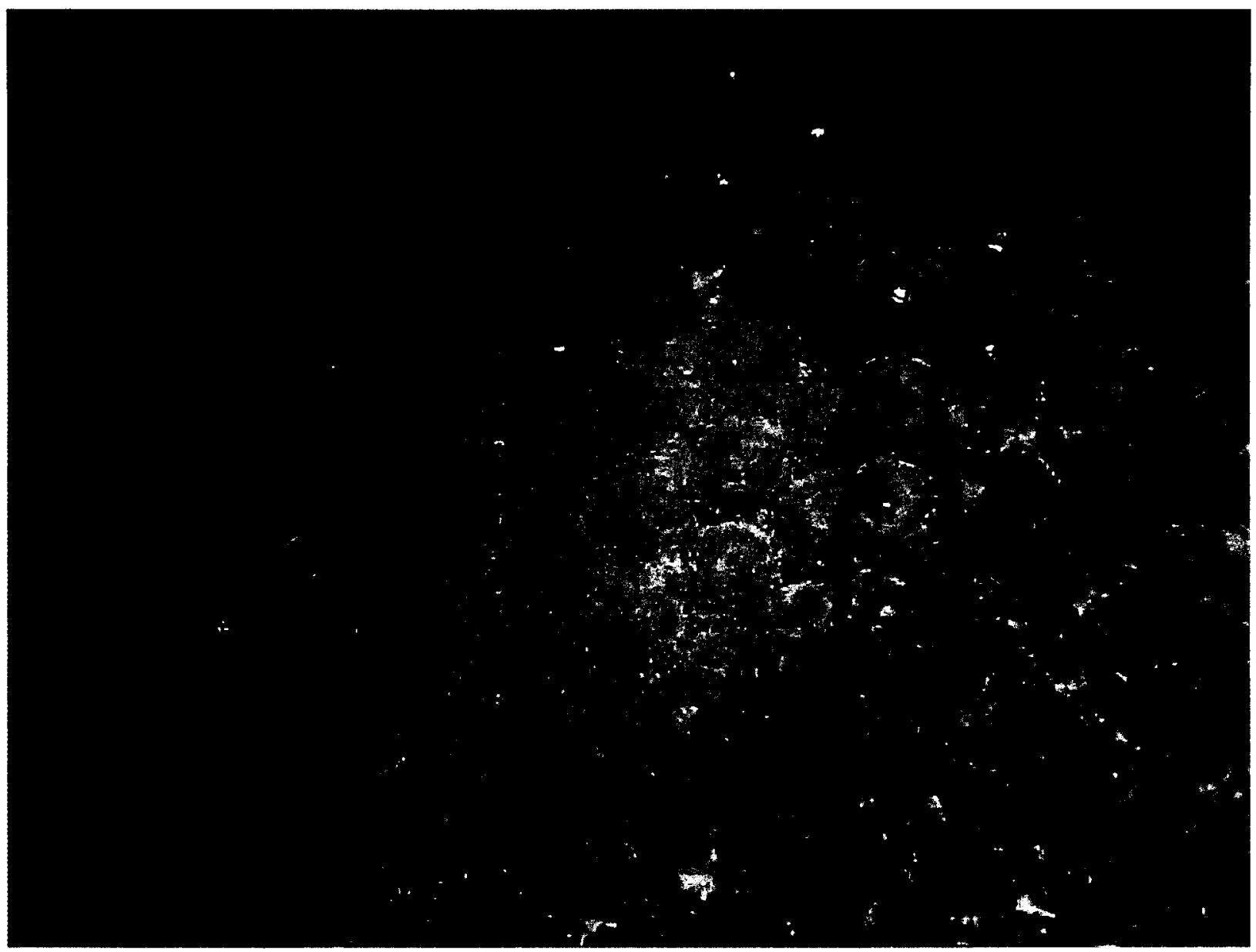

Photo II-5. Close-Up of Column Bottom, Two Ball Bearing Layers Exposed. 


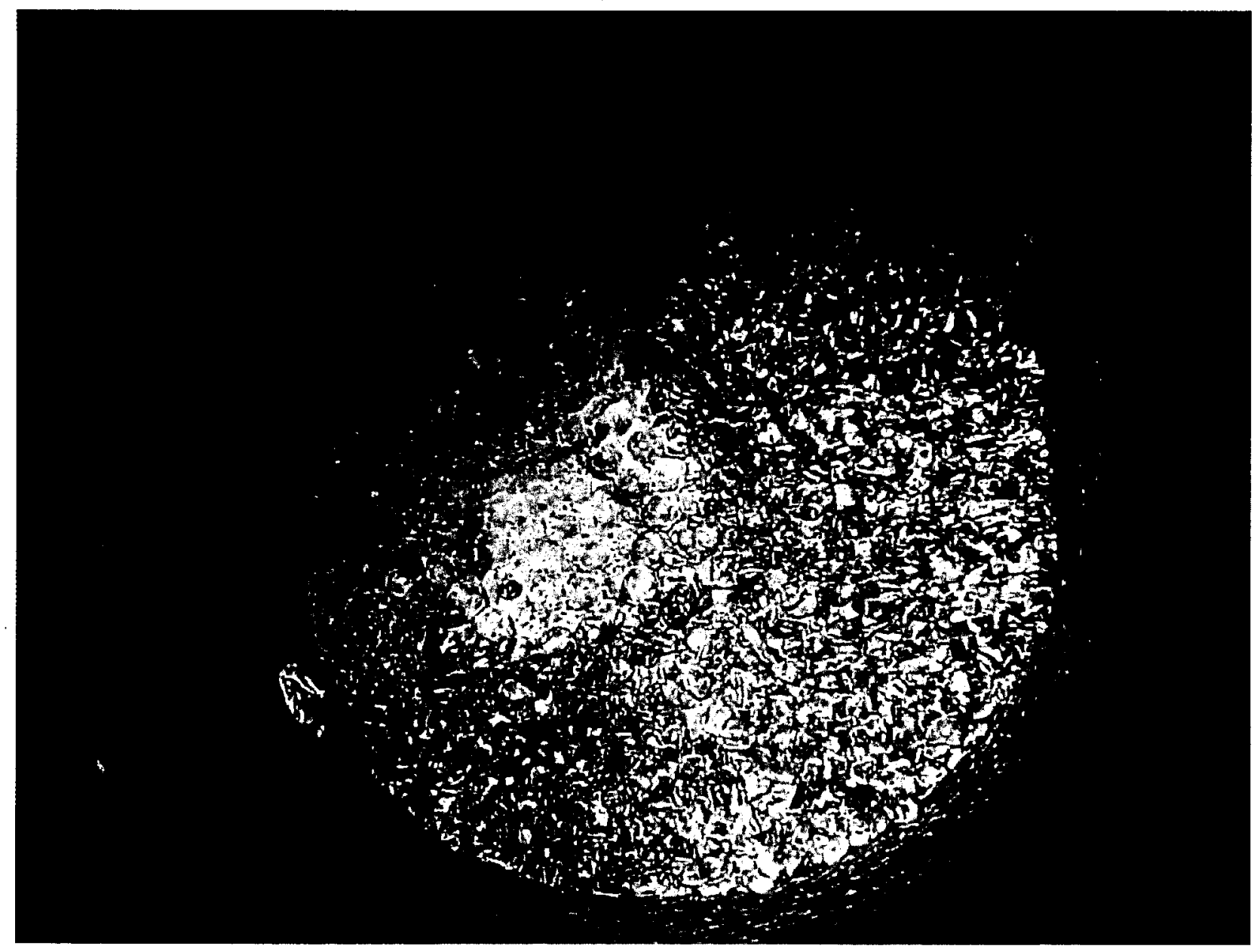

Photo II-6. Column Bottom With Cemented Tuff, Cemented Tuff and Ball Bearing Layers Exposed. 


\section{ATTACHMENT III}

WATER LOSS DURING AIR SAMPLING OF COLUMN TEST 3

(Source: DTN\#MO0107EBSTHCT3.007) 


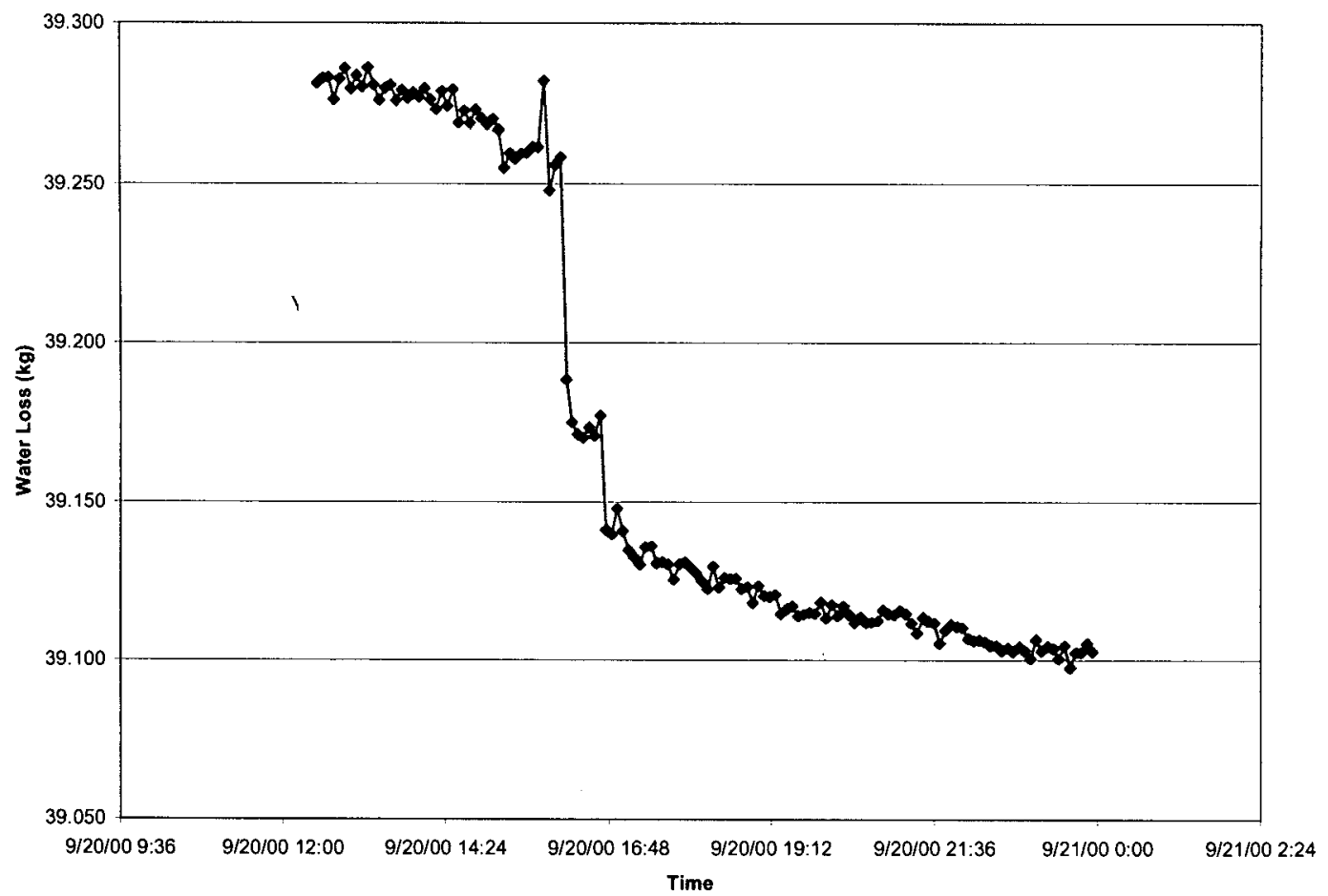

Plot III-1: Water Loss During Column Air Sampling On September 20, 2000

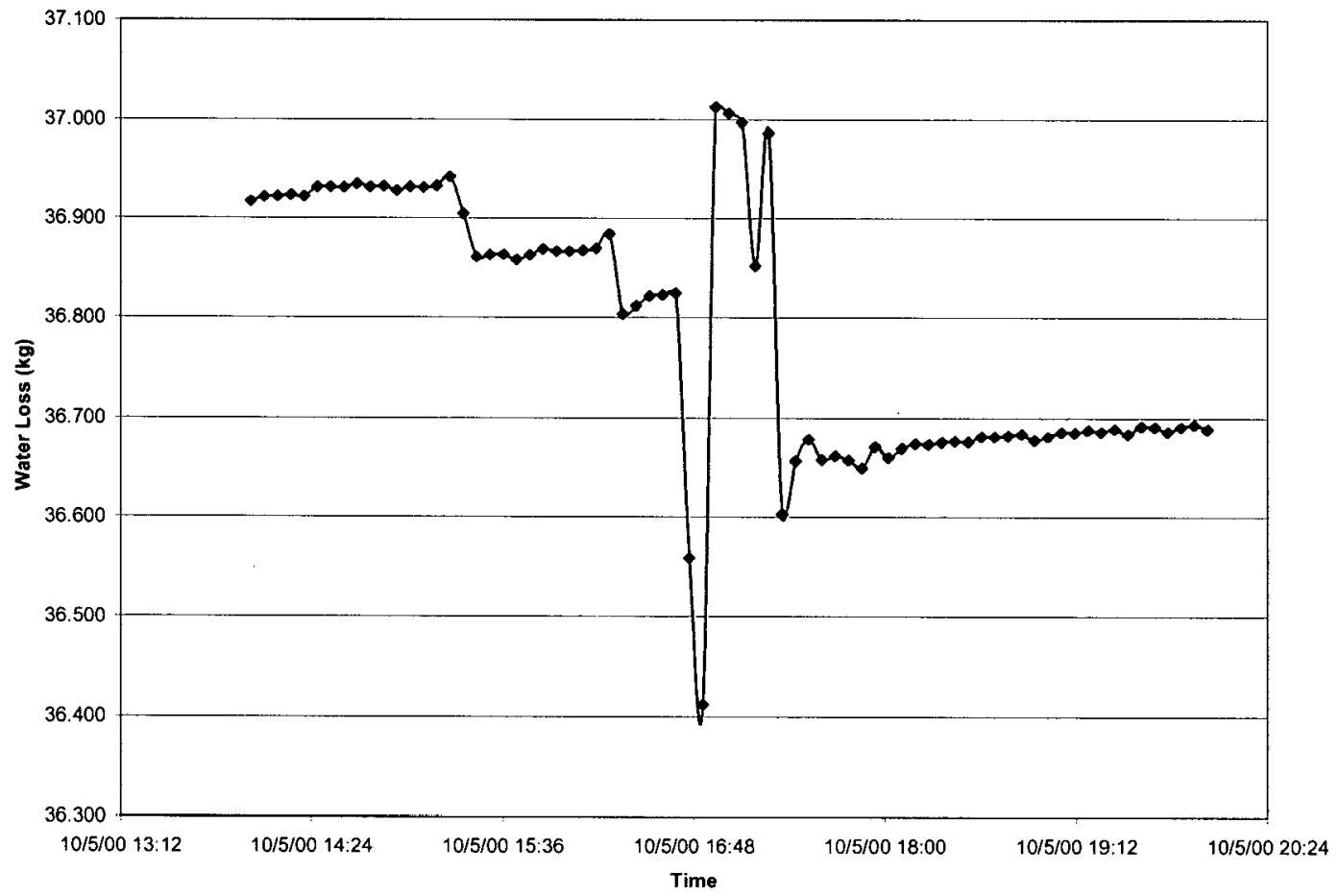

Plot III-2: Water Loss During Column Air Sampling On October 5, 2000 


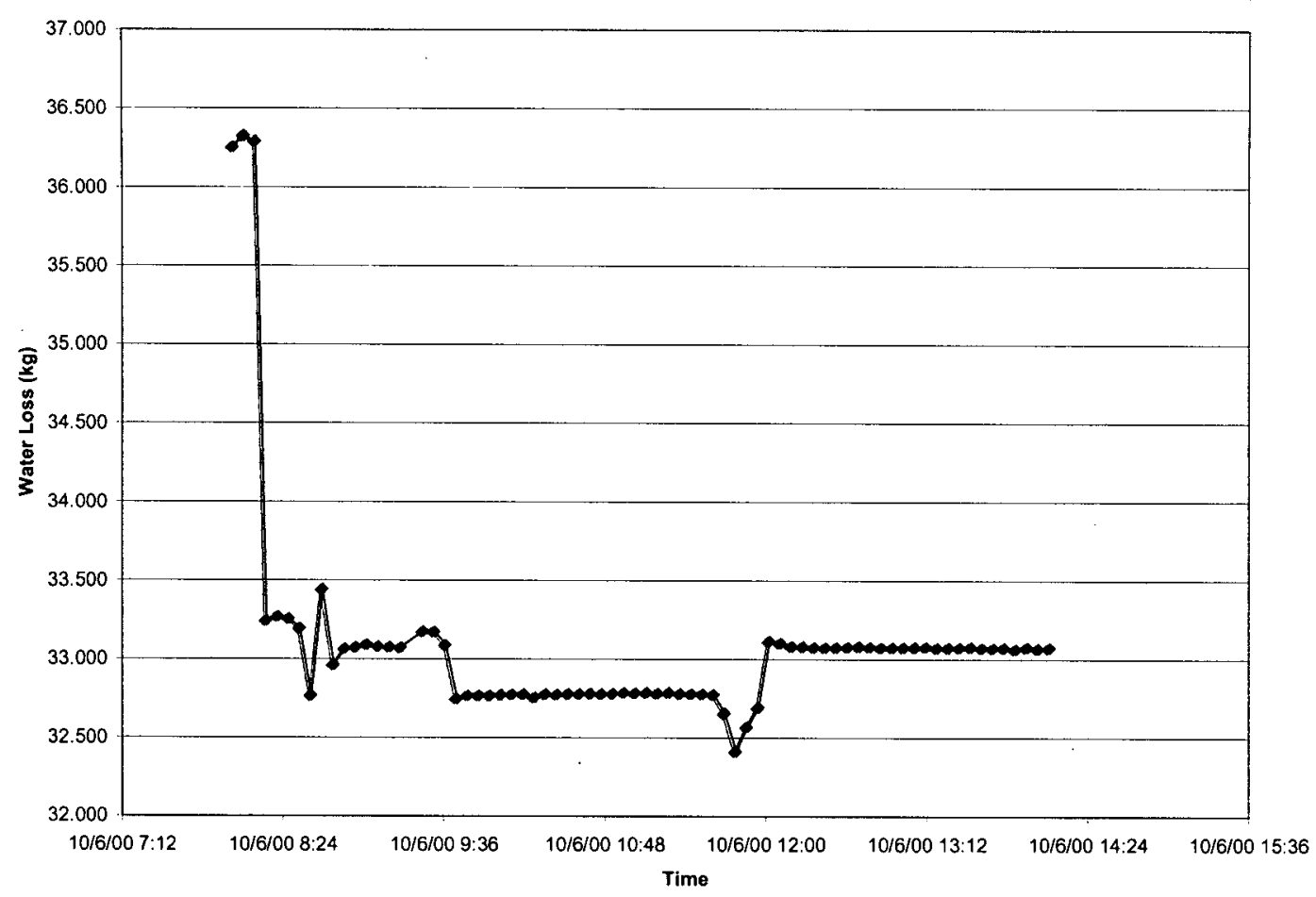

Plot III-3: Water Loss During Column Air Sampling On October 6, 2000

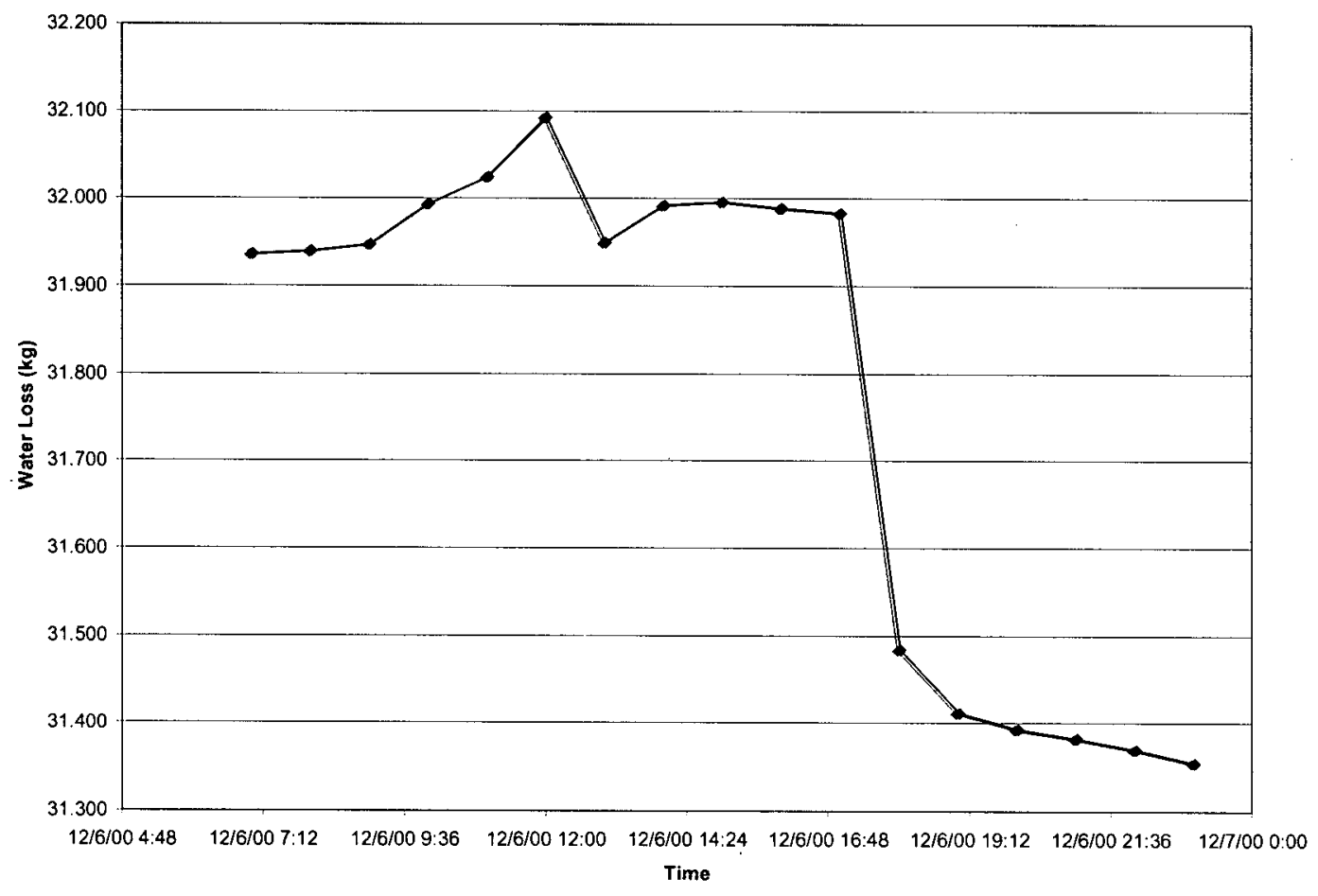

Plot III-4: Water Loss During Column Air Sampling On December 6, 2000 


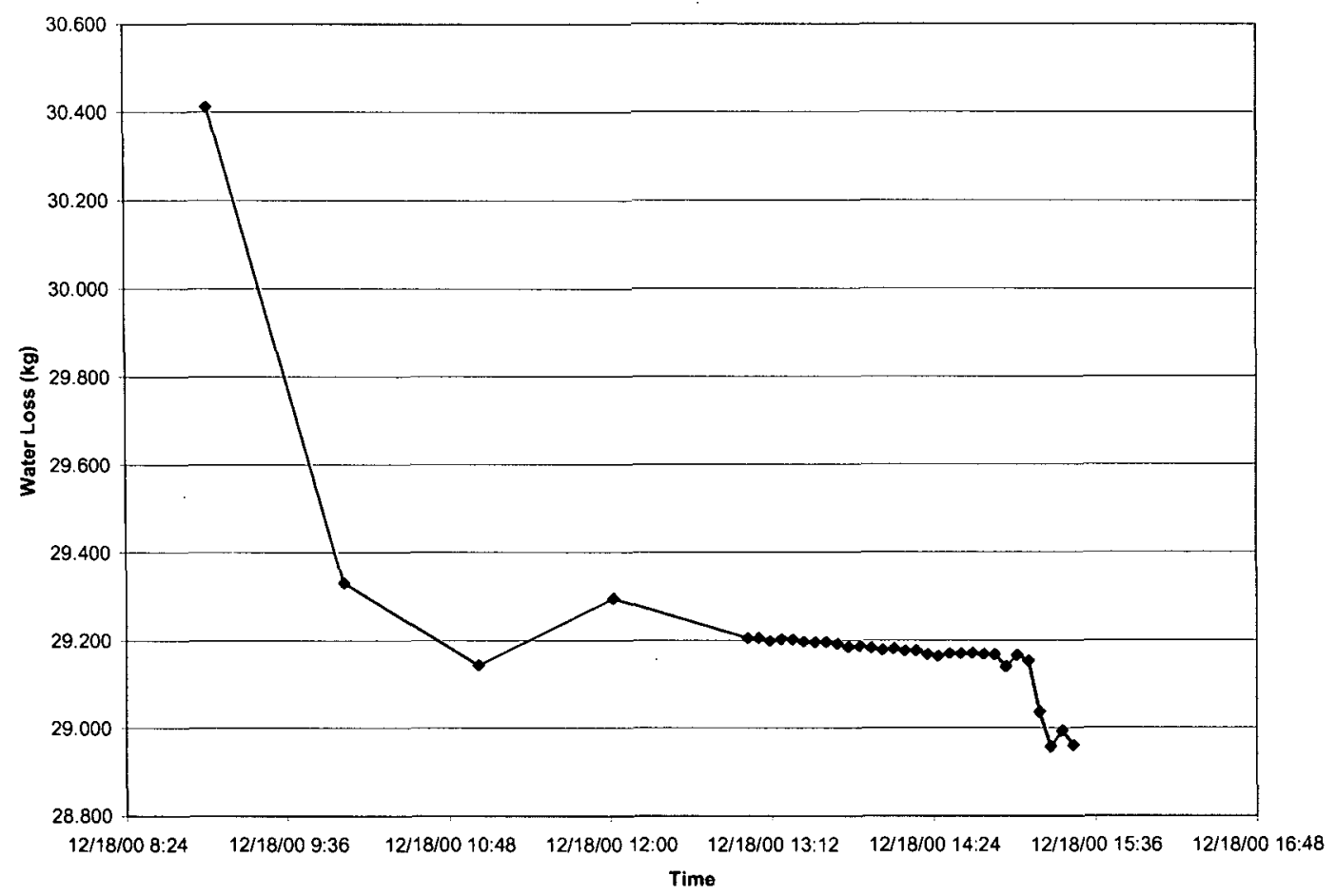

Plot III-5: Water Loss During Column Air Sampling On December 18, 2000

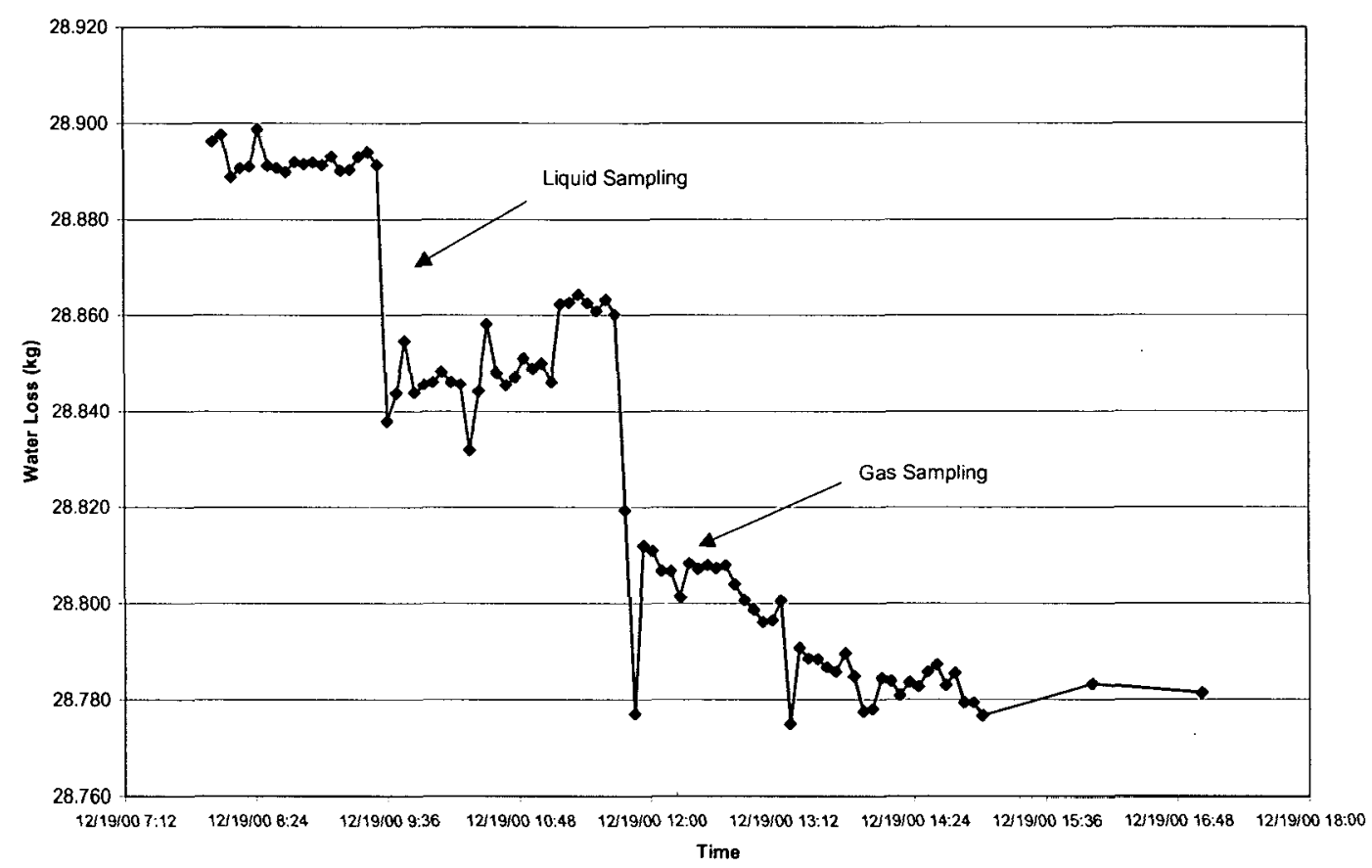

Plot III-6: Water Loss During Column Air Sampling On December 19, 2000 


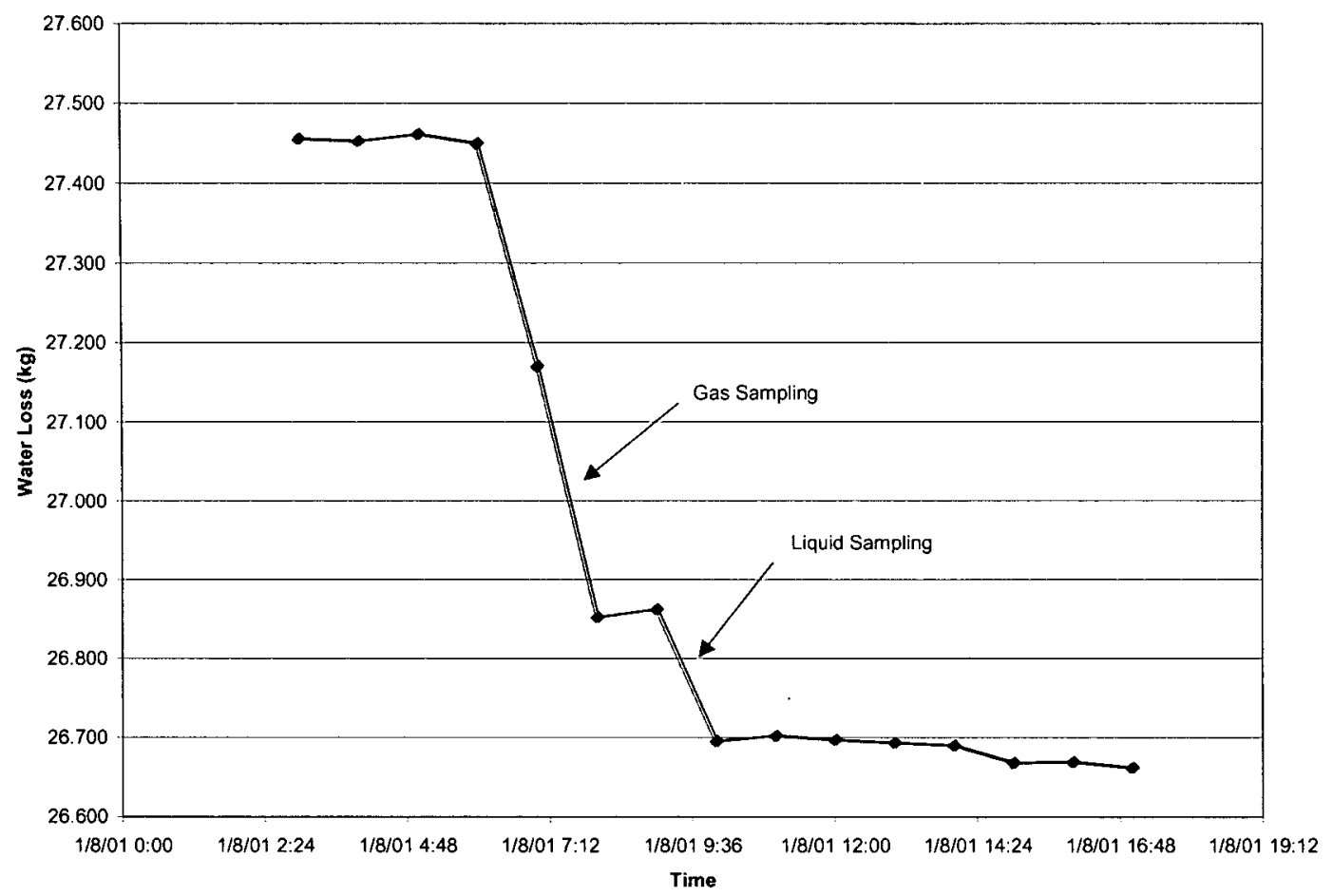

Plot III-7: Water Loss During Column Air Sampling On January 6, 2001

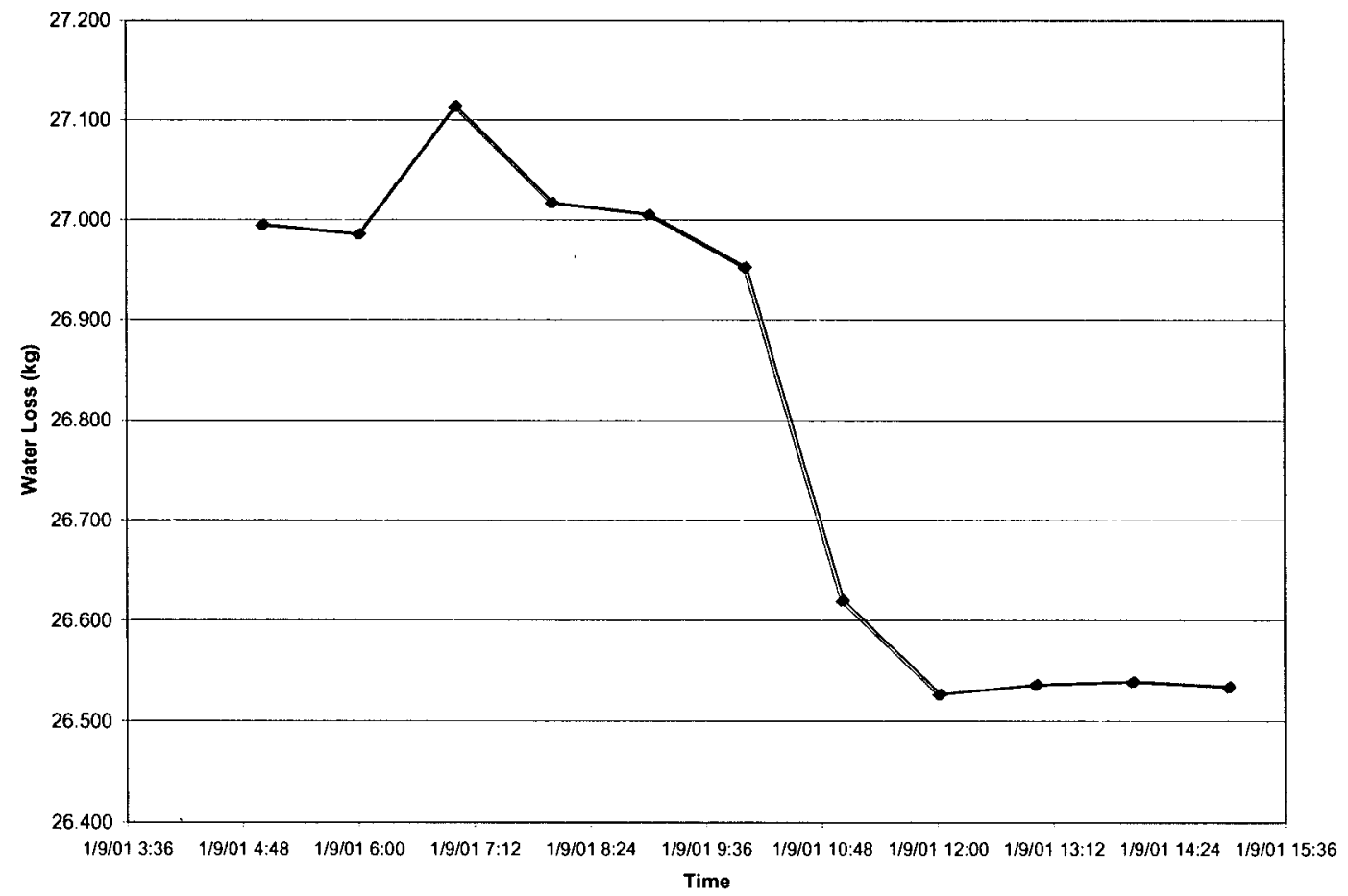

Plot III-8: Water Loss During Column Air Sampling On January 9, 2001 


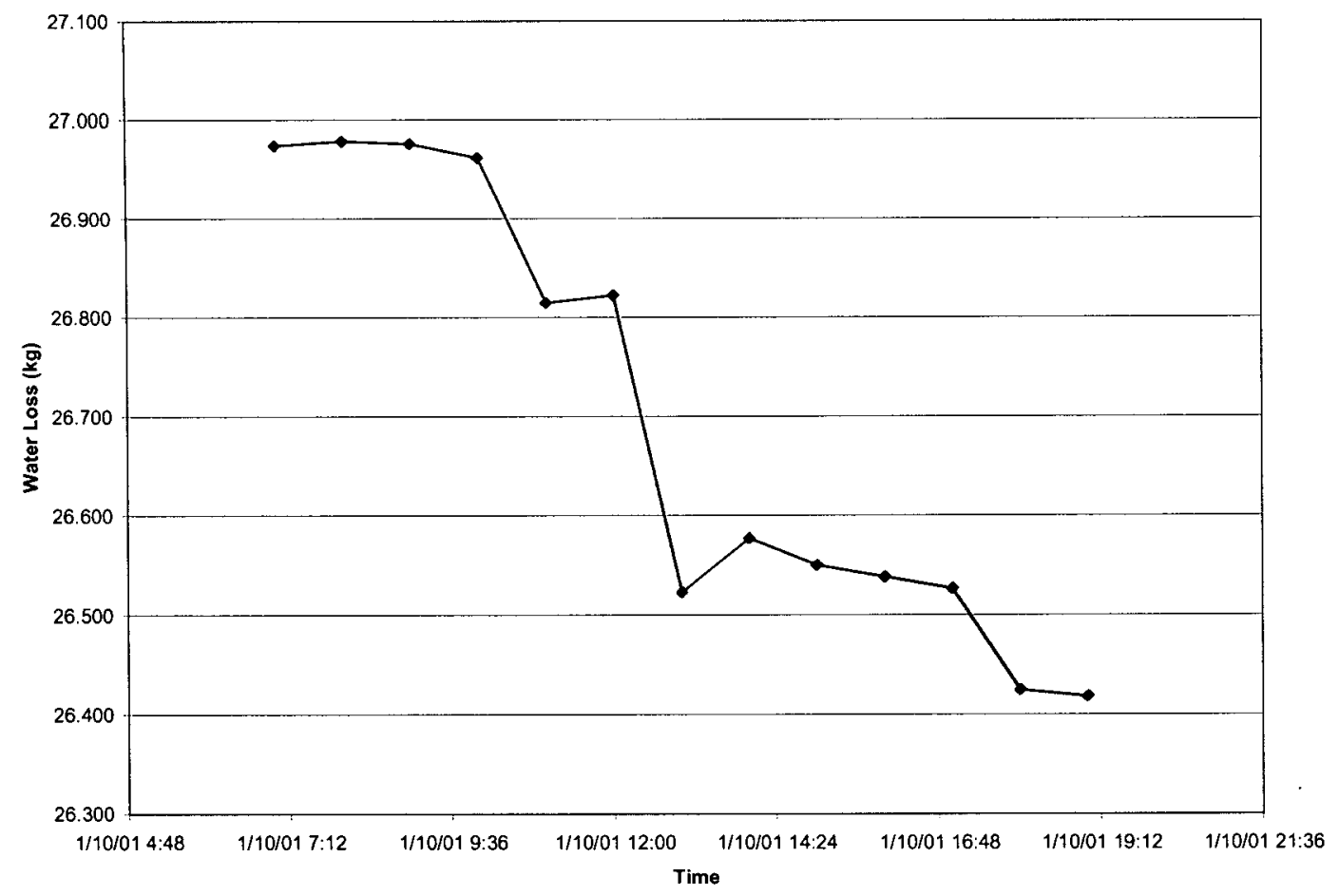

Plot III-9: Water Loss During Column Air Sampling On January 10, 2001 